\title{
RELATIONSHIP BETWEEN PREWEANING GROWTH RATE OF \\ FEMALE LAMBS AND THE GROWTH \\ OF THEIR OFFSPRING
}

\author{
By \\ MIKE B. GOULD \\ Bachelor of Sclence \\ Oklahoma State University \\ St111water, Oklahoma \\ 1962 \\ Master of Sclence \\ Oklahome State Unfversity \\ Stillwater, Oklahoma \\ 1970
}

Submitted to the Faculty of the Graduate College of the Oklahoma State University

in partial fulfillment of the requirements

for the Degree of

DOCTOR OF PHILOSOPHY

May, 1973 


\section{RELATIONSHIP BETWEEN PREWEANING GROWTH RATE OF}

FEMALE LAMBS AND THE GROWTH

OF THEIR OFFSPRING

Thesis Approved:
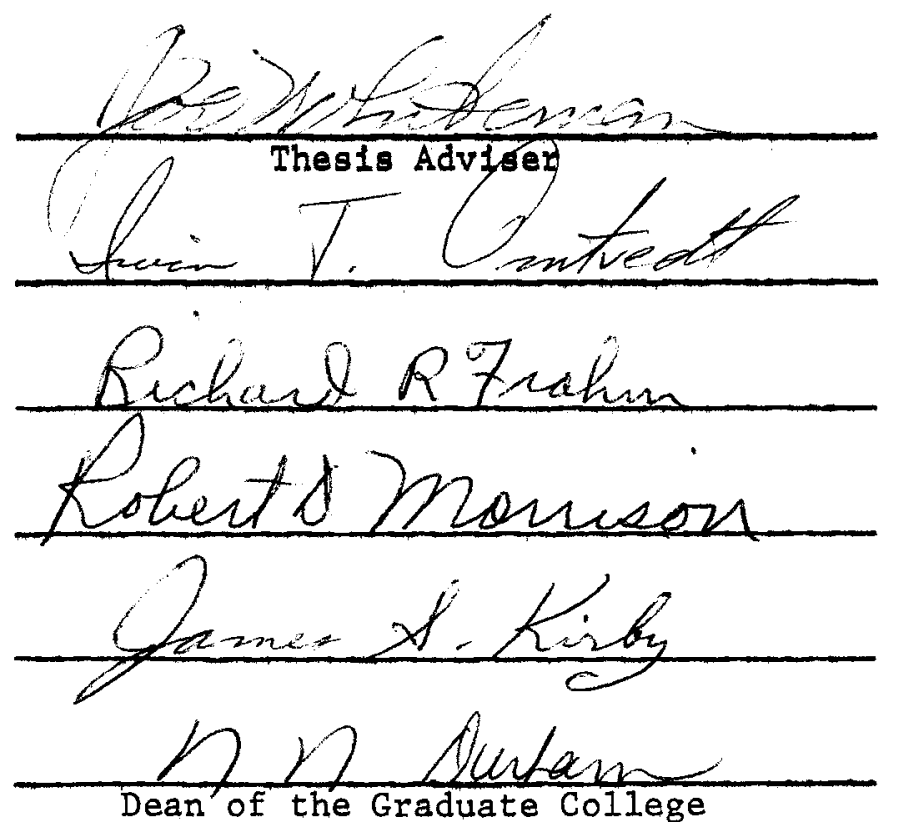


\section{ACKNOWLEDGMENTS}

The author wishes to express his sincere appreciation to Dr. Joe $V$. Whiteman, Professor of Animal Science, for his guidance and counsel during the duration of this study and the preparation of this thesis. The author also extends thanks to Dr. R. R. Frahm, Associate Professor of Animal Science, Dr. I. T. Omtvedt, Professor of Animal Science, Dr. J. S. Kirby, Assistant Professor of Agronomy and Dr. R. D. Morrison, Professor of Mathematics and Statistics for their very valuable contributions to this thesis and for critiquing the manuscript.

The author is also Indebted to Dr. R. D. Morrison for his very valuable assistance in the statistical analyses of the data.

A very special thanks goes to the author's wife, Ruth Ann, for her understanding, sacrifice and encouragement during the course of this study. 
TABLE OF CONTENTS

Chapter

Page

I. INTRODUCTION ............. . . . . 。 。 . 1

II. LITERATURE REVIEW .............. . . 。. 4

Body Development, Production and Reproduction ..... 5

Milk Production . . . . . . . . ........ 9

Ewe Size and Productivity .............. 14

Heritability Estimates of Body Weights . . 。 。 . . 17

Ewe Milk Production and Lamb Gain . . . . . . . . . 17

Phenotypic Correlations Between Ewe and Offspring

Performance ................ 20

Twin Vs. Single-Born Dams ............. 21

III。 MATERIALS AND METHODS . . . . . . . . . . 25

Management of the Raised Ewes from Birth to their

First Lambing ............... 26

Standard Flock Management . . . . . . . . . 27

Statistical Analyses ............... 32

Initial Lamb Data Adjustments ......... 32

Methods of Analyzing the Data to Determine

the Relationship Between Early Ewe Lamb

Nutrition and Subsequent Milking Ability . . . 34

Phenotypic Relationships Between Ewes and their offspring ............ 34

Group Comparisons of the Birth Weights

and Subsequent Gains of Lambs Born

to the Single and Twin-Reared Ewes ...... . 37

Analyses of Data to Estimate Repeatability

of the Various Lamb Traits . . . . . . . 39

IV. RESULTS AND DISCUSSION . . . . . . . . . . 41

Relationship Between Ewe Lamb Growth from Birth

to 70 Days and the Growth of their Progeny . . . . . 42

Birth Weight . . . . . ......... 42

Gain From Birth to 70 Days of Age ....... 48

70-Day Welght ................ 55

Dam Gain From Birth to 70 Days and

Offspring Gain From 70 Days (Weaning)

to Market ............ 56

Birth Weights and Preweaning Growth Rates of

the Dams in This Study ............ 59 
Birth Weights and Preweaning Performance of

Lambs Born to the Single.Vs. Twin-Reared Dams . . . 61

B1rth Weight ............... 61

Lamb 70-Day Welght .......... 65

Lamb Galn From Birth to 70 Days of Age . . . . 69

Lamb Gains From 70 Days to Age of Market . . . . 70

Relationships Among Maternal Half-Sibs .....。. 71

V. SUMMARY . . . . . . . . . . . 。 。 。 。 78

LITERATURE CITED 。. . . . . . . . . . . . . . 83

APPENDIX ................. . . . . . 88 
LIST OF TABLES

Table

Page

I. Lactation Information for Dairy and Dual

Purpose Cattle.......... . . . . . . 。 10

II. Genetic Correlations Among Traits for Ramboulllet Ewes 。. 16

III. Heritability Estimates of Birth and Subsequent Gain

Based on Varfous Breeds of Sheep............ 18

IV。- Lambing Observations of Twin vs。Single-Born Ewes . 。 . 22

V. Observation Matrix: Number of Ewes Utilized

(Classified by Year of Birth, Age at First

Lambing and Type of Rearing) 。. . . . . . . 。 28

VI。 Numbers of Lambs Utilized by Ewe Class 。. . . . . . 31

VII。 Mean Birth Weights, 70-Day Weights, Average Daily

Gain Birth to 70 Days, Average Daily Gain 70

Days to Market, and Estimates of $\hat{\beta}_{i}$ of

Associated Varlables ... . . 1。. . . . 。 。 35

VIII. Simple Phenotypic Correlation Coefficients Between

Ewe Birth Weight and Her Various Lamb Birth

Weights With the Data Pooled Over Age of Dam

at First Lambing and Over Dam Type of Rearing

and Presented by Age of Dam 。. . . . . . . . . 46

IX. Simple Phenotypic Correlations Between Ewe Average

Daily Gain From Birth to 70 Days and Her Lamb

Gains From Birth to 70 Days Pooled Over Age of

Dam at First Lambing and Over Dam Type of

Rearing and Presented by Age of Dam . . . . . . . 52

X. Simple Phenotypic Correlations Between Ewe 70-Day

Weight and Her Lamb 70-Day Weights Presented for

Each Age of Dam With the Data Pooled Over Age of

Dam at First Lambing and Over Dam Type of Rearing . . 。

XI. Birth Weights and Gains to 70 Days of Age of the

240 Dams (Least Squares Means) 。. 。 。. ..。。 
XII。 Simple Phenotypic Correlations ( $r$ ) Between Various Lamb Records for Several Traits and Simple Linear Regressions (b) of Certain Later Lamb Records on Earlier Records for Lambs Born to the Single and Twin-Reared Dams (Pooled Over Age of Dam at First Lambing .........................

XIII。 Simple Phenotypic Correlations ( $r$ ) Between Various Lamb Records for Several Traits and Simple Linear Regressions (b) of Certain Later Lamb Records on Earlier Lamb Records (Pooled Over Age of Dam at First Lambing and Over Dam Type of Rearing) . . . . 。

XIV。 Simple Phenotypic Correlations Between the Ewes'

Birth Weight and the Birth Weights of Her

Lambs for the Four Classes of Ewes by Age of Dam . . 。

XV. Simple Phenotypic Correlations Between the Ewe's Gain From Birth to 70 Days and the Gain of Her Lambs From Birth to 70 Days, and Between the Ewe's 70-Day Weight and the 70-Day Weight of Her Lambs Presented by Age of Dam...........

XVI。 Simple Phenotypic Correlations Between the Ewe's Gain From Birth to 70 Days and the Gain of Her Lambs From 70 Days to Market Presented by Age of Dam . . . . . . . . . . . . . . 。

XVII. Simple Phenotypic Correlations Between the Ewe's Birth Weight and Her Lamb's Birth Weights, the Ewe's Gain From Birth to 70 Days and the Corresponding Gain of Her Lambs, the Ewe's 70-Day Weight and the 70-Day Weight of Her Lambs, the Ewe's Gain From Birth to 70-Days and the Postrwepning Gain of Her Lambs (Pooled Over Age of Ewe at First Lambing) for Single and Twin-Reared Ewes by Age of Dam . . . . 。

XVIII. Simple Phenotypic Correlation Coefficients Between Ewe Gain From Birth to 70 Days and Gain of Her Lambs from 70 Days to Market Pooled Over Age of Dam at First Lambing and Over Dam Type of Rearing and Presented by Age of Dam

XIX. Means (Least Squares) by Year of Birth For Ewe Birth Weights, Gains From Birth to 70 Days and 70-day Weights for the Dams in This Study .....

XX. Analysis of Variance of Birth Weight for the Lambs Born to the Single and Twin-Reared Dams . . . . 。 。 
Table

XXI. Mean Birth Weights and Estimates of $\hat{\beta}_{i} a$ of Associated Variables for the Lambs Born to the Single and Twin-Reared Dams ........... 96

XXII. Analysis of Variance of Gain From Birth to 70 Days of the Lambs Born to the Single and Twin-Reared Dams . . 97

xxIII. Mean Gain From Birth to 70 Days and Estimates of $\hat{B}_{i}{ }^{a}$ of Associated Variables for the Lambs Born to the Single and Twin-Reared Dams ............

XXIV. Analysis of Varlance of 70-Day Welght of the Lambs Born to the Single and Twin-Reared Dams ........

XXV. Mean 70-Day Welght and Estimates of $\hat{\beta}_{i}{ }^{a}$ of Associated Variables for the Lambs Born to the Single and Twin-Reared Dams ........... 100

XXVI. Analysis of Variance of Gain From 70 Days to Market of the Lambs Born to the Single and Twin-Reared Dams . . . 101

XXVII. Mean Gain From 70 Days to Market and Estimated $\hat{\beta}_{i}{ }^{a}$ of Associated Variables for the Lambs Born to The Single and Twin-Reared Dams ...........

XXVIII. Mean (Least Squares) Lamb Birth Weights and Subsequent Performance to Market of Lambs Born to the Single and Twin-Reared Dams Lambing First at 15 and

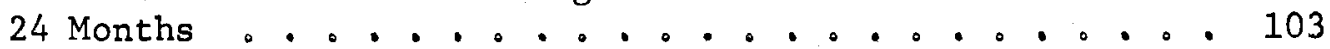

XXIX。 Mean (Least Squares) Birth Weights and Subsequent Performance to Market of Lambs Born to the Single and Twin-Reared Dams ............ 104

xxx. Simple Phenotypic Correlations ( $r$ ) Between Certain Lamb Records for Varlous Traits and Simple Linear Regressions (b) of Certain Later Lamb Records on Earller Lamb Records for Lambs Born to the Four Groups of Ewes. . . . . . . . . 105

XXXI. Simple Linear Regression Coefficients (b) of Lamb Traits on Ewe Traits for the Four Groups of Ewes and Presented by Age of Dam ............ 107

XXXII。 Simple Linear Regression Coefficients (b) of Lamb Traits on Ewe Traits for Single and Twin-Reared Ewes Presented by Age of Dam (Pooled Over Age of Ewe at First Lambing) . . . . . . . . . . . 


\section{LIST OF FIGURES}

Figure

Page

1. Breeding and Lambing Periods for the Dams in

This Study.... . . . . . . . . . . . . . . 29

2. Simple Phenotypic Correlations ( $r$ ) Between Ewe

Birth Weight and Her Various Lamb Birth

Weights Presented by Age of Dam . . . . . . . . . . 44

3. Simple Phenotypic Correlations ( $r$ ) Between Ewe

Birth Weight and Her Various Lamb Birth

Weights Pooled Over Age of Dam at First

Lambing and Presented by Age of Dam . . . . . . . . . 45

4. Simple Phenotypic Correlations ( $r$ ) Between Ewe

Birth Weight and Her Various Lamb Birth

Weights With the Data Pooled Over Age of

Dam at First Lambing and Over Dam Type of

Rearing and Presented by Age of Dam . . . . . . . . . 47

5. Simple Phenotypic Correlations ( $r$ ) Between Ewe

Gain From Birth to 70 Days and the Gains From

Birth to 70 Days of Her Lambs Presented by

Age of Dam .. . . . . . . . . . . . . . . . . 49

6. Simple Phenotypic Correlations ( $r$ ) Between Dam Gain

From Birth to 70 Days and the Gain of Her Lambs

From Birth to 70 Days With the Data Pooled Over

Age of Dam At First Lambing and Presented by

Age of Dam ........................ 50

7. Simple Fhenotypic Correlations ( $r$ ) Between Ewe Gain

From Birth to 70 Days and the Gain of Her Lambs

From Birth to 70 Days With the Data Pooled Over

Age of Dam at First Lambing and Over Dam Type

of Rearing and Presented by Age of Dam . . . . . . . . . 53

8. Simple Phenotypic Correlations ( $r$ ) Between Ewe

70-Day Weight and Her Lamb 70-Day Weights

With the Data Pooled Over Age of Dam at

First Lambing and Over Dam Type of Rearing

and Presented by Age of Dam ............. 58 
Figure

9. Mean Birth Weights of Lambs Born to Single and Twin-Reared Ewes Lambing First at 15 or 24 Months Presented by Age of Dam 。. . . . . 。 . . 63

10. Mean Lamb Birth Weights of Lambs Born to Single and Twin-Reared Dams Presented by Age of Dam With Data Pooled Over Age of Dam at First Lambing . . . . . . . . 64

11. Mean Lamb 70-Day Weights of Lambs Born to Single and Twin-Reared Dams Lambing First at 15 or 24 Months Presented by Age of Dam .................。

12. Mean Lamb 70-Day Weights of Lambs Born to Single and Twin-Reared Dams Presented by Age of Dam With the Data Pooled Over Age of Dam at First Lambing . . . . . . 68

13. Simple Phenotypic Correlations ( $r$ ) Between Dam Gain From Birth to 70 Days and Her Offspring Gains From 70 Days to Market Presented by Age of Dam . . . . . . . 109

14. Simple Phenotypic Correlations ( $r$ ) Between Dam Gain From Birth to 70 Days and Her Offspring Gains From 70 Days to Market Presented by Age of Dam With the Data Pooled Over Age of Dam at First Lambing . . . . . 110

15. Simple Phenotypic Correlations ( $r$ ) Between Dam Gain Preweaning and Her Various Lamb Gain Post-weaning (Pooled Over Age of Dam at First Lambing and Over Dam Type of Rearing) and Presented by Age of Dam . . . . . 111

16. Mean Gains From Birth to 70 Days of Age for Lambs Born to Single and Twin-Reared Dams Lambing First at 15 or 24 Months and Presented by Age of Dam . . . . . 112

17. Mean Lamb Gains From Birth to 70 Days for Lambs Born to Single and Twin-Reared Dams Presented by Age of Dam With Data Pooled Over Age of Dam at First Lambing ....................... . . 11

18. Mean Lamb Gains From 70 Days to Market for Lambs Born

to Single and Twin-Reared Dams Lambing First at 15

or 24 Months and Presented by Age of Dam . . . . . . . 。 114

19. Mean Lamb Gains From 70 Days to Market for Lambs Born to Single and Twin-Reared Dams Presented by Age of Dam With Data Pooled Over Age of Dam at First 


\section{CHAPTER I}

\section{INTRODUCTION}

It has been suggested from research involving both beef and dairy females that the nutritional environment provided heifers from birth to weaning may be negatively associated with the maternal environment these females eventually provide their offspring. If this circumstance exists relative to ewes, then the selection of fast growing ewe lambs to be breeding flock replacements may result in poorer milking ewes as compared to the selection of slower growing ewe lambs.

The relationship between dam and offspring performance is both genetic and maternal. Genetically, the offspring receives a random half of the dam's genes for growth and the dam also influences the offspring's growth maternally through milk production. The dam influences the offspring both prenatally and postnatally. The prenatal influence is expressed as birth weight while the postnatal effect is expressed primarily through milk production very early in life. In sheep, about 80 to 80 percent of the variation in lamb 70-day weight can be accounted for by differences in lamb birth weights and milk consumption by the lamb.

Data available from research involving single and twin-reared ewes at the Fort Reno Livestock Research Station at E1 Reno, Oklahoma should allow evaluation of the relationship between very early nutritional environment of ewe lambs and their subsequent milk producing abilities. Data were available on the single and twin-reared dams for birth weight 
and preweaning growth rate. Data were available on their offspring for birth weight, preweaning growth rate and weaning weight. So even though milk production estimates as such were not avallable on the ewes, the established high relationship between milk consumption and lamb growth should allow relatively accurate estimates of the milk producing abilities of the single and twin-reared dams in this study. Records were available relative to the production performance of 129 single and 111 twin-reared ewes. The single-reared ewes were about one pound heavier at birth, gained considerably faster to weaning at 70 days $(0.15$ pounds per day) and were therefore about 10 pounds heavier at 70 days of age than the twin-reared ewes.

The data could be analyzed in two basic ways in order to estimate the relationship between very early nutrition of the ewe lambs and their subsequent milking abilities. First, phenotypic relationships (for traits birth weight, gain to weaning at 70 days and 70 -day weight) between the ewes and their lambs should yleld information relative to the relationship between preweaning ewe lamb nutrition and subsequent growth of their offspring. However, since confounding of direct additive genetic and maternal effects is expected, usefulness of these phenotypic relationships became somewhat limfted relative to estimating the relationship between early nutrition of ewe lambs and their subsequent milking abilities. The second method of analyses, comparing the birth weights and gains up to 70 days of age of lambs born to the single and twin-reared ewes, should provide information relatively free of the direct additive genetic effect, relatfve to the relationship between early ewe lamb nutrition and subsequent milking abilities. Thus, the primary objectives of this study were: 
1. To evaluate the phenotypic relationships within dam type of rearing class between the growth of ewes and of their lambs to establish the total (genetic plus environmental) apparent relationship.

2. To evaluate the influence of type of rearing of dam on the growth performance of their lambs to determine if different environmentally induced rates of early growth influences the milking abilities of these two classes of ewes.

Secondary objectives of this study were:

1. To evaluate the phenotypic relationships (repeatability) among maternal half-sib lambs born to single or twin-reared ewes. 


\section{CHAPTER II}

\section{LITERATURE REVIEW}

The possible interaction of heredity and environment may involve several problems of importance in domestic animal production. One such problem may be the influence of or the relationship between nutritional level during the early rearling period and subsequent body development, fertility, production and reproduction of the female. Some information relative to early nutrition and subsequent production is available relative to beef and dairy females, but very little is available concerning sheep. Relative to sheep, the possible interaction between early developmental nutrition levels and subsequent maternal ability might be manifested In relation to single and twin-reared ewes since these two types of ewes normally grow at greatly different rates early in life. Further, the milking ability and factors influencing the milking ability of the ewe might be of greater importance than the milking ability of the cow because of the greater variation in litter size in sheep and also since many lambs commerclally produced are very dependent of the ewe's milk supply until marketing time, or at least until they have achieved a greater proportion of their slaughter weight than is normal for cattle.

This literature review will be concerned with the general relationships between early nutritional environment of females and their subsequent production, reproduction, body development and fertility. 
Also, reproduction and production of twin versus single-reared ewes w1ll be characterized.

Body Development, Production and Reproduction

Swanson and Spann (1954) ut1lized Identical twin grade Jersey helfers whlch were divided at three months of age, after which one group was fed concentrates ad $11 \mathrm{~b}$. and the other was fed normal 100 percent of recommended levels with no grain after one year of age. The grain-fed helfers fattened and grew rapldly compared to the normal-fed group. At breeding age, 15 months, the averages for the super and normal growth groups, respectively, were 628 and 548 pounds body welght. Just before first calving at about 24 months of age they averaged 912 and 781 pounds, respectively. After flrst calving, both groups were fed at recommended nutritional levels, Subsequent milk productions are presented later for two palr of twins.

Joubert (1954) found that Jersey, Holstein and Shorthorn females fed high nutritional levels during very early growth had heavier calves at first calving than cows on low levels, but later welghts Indicated that the prenatal nutritional level of the dam had no permanent association with growth of the progeny. In a similar study, Reld et al. (1957) reported that Holstein females (helfers) fed at low nutritional levels from birth to weaning had calves that were smaller at weaning than calves from helfers fed at normal and above normal nutritional levels. But expressed as a percent of dam's welght, the blrth welghts of first calves were $9.7,8.3$ and 7.8 percent, respectlvely, for low, medlum and hIgh level groups. 
Hansson (1956) evaluated early nutritional levels in several trials and Indicated possible interactions of heredity and environment in several respects. In two trials, 17 pairs of identical twins over a two year period were used. One heifer of each pair was fed much below recommended levels while the other was fed much above recommended levels from one month of age to first calving. After first calving, all heifers were fed at recommended levels. In these trials the intensity of rearing had a great influence upon rate of growth, but size and conformation of the adult body were only slightly affected. In a third trial, 16 pairs of one-egg (monozygotic) twins were divided into four groups of equal numbers of pairs. Within each pair one twin (control) was reared on a standard nutritional level while the twin sister (experimental) received from 1 to 25 months of age a certain predetermined proportion of the feed given the control twin. Expressed as a percentage of the standard level of nutrition, the experimental levels were fixed at $60,80,120$ and 140 . From 25 months on both females of each pair recelved standard levels. In a fourth trial, 27 pairs of one-egg twin females were handled as in trial three except the experimental levels were $40,60,60,80$ and 120 . In one of the groups kept on the 60 percent level the feeding remained unchanged to the first calving. In all the other groups the experimental levels were gradually changed from the fourth month of gestation so that at calving all twins were standard-fed. The growth of the females in trials three and four (grams per day) were 298, 444, 542,624,691 and 689 for the $40,60,80$, Normal, 120 and 140 percent intensities of feeding. The animals reared on the very low levels responded very efficiently to increases in levels of nutrition when the levels were raised to standard levels. Further, age at first heat was associated 
with the different feeding levels used in trials three and four with the 40, 60, 80, Normal and 120 percent rearing levels showing first heat in $13.3,12.5,10.9,10.4$ and 10.6 months, respectively.

Reid et al. (1957) evaluated effects of amount of nutrients available from birth to first calving on subsequent performance using Holstein females. Feeding levels were 65,100 and 140 percent of Morrison's (1956) standards. After first calving the groups received TDN levels of 118, 109 and 100 percent for the low, medium and high groups, respectively. After second calving all groups were fed at levels according to Morrison's standards. Even though the group maintained on the high level of nutrition in early life maintained a weight advantage through seven years of age, the low level heifers showed the capacity to respond to adequate feed in later life. Also, age at sexual maturity seemed to be associated with the different levels. However, all females tended to exhibit first estrus at about the same body development stage. Though there was no consistent effect upon conception rates, through the fifth calving the higher nutritional levels had resulted in more open cows. A later report by Reid (1960) indicated no differences in number of services. The percent conceiving at first service was: low, 79; medium 68; high, 58 percent.

Crichton, Aitken and Boyne (1959) used 18 pairs of monozygotic and six pairs of dizygotic dairy twins to evaluate the following characteristics: (1) A continuous high level of nutrition from birth to first calving; (2) A high level for the first 44 weeks followed by a low level until two months before calving; (3) A continuous low level until two months before calving; and (4) A low level for the first 44 weeks followed by a high level until first calving. The high level was 
accomplished by utilizing 110 percent of the Ragsdale (1934) recommendations and the low by using 60 percent. Results indicated that all groups reached sexual maturity at about the same developmentai stage but at different ages. These same four schemes of rearing were studied by Crichton et al. (1960) to evaluate the effects on growth rate to maturity. Indications were that all groups differed in the age at which maturity was reached. By about six years of age all groups had reached about the same body size. Thus, the age at which females became sexually mature seemed to be associated with early nutrition levels. In many studies, nutritional levels much below standards considered adequate resulted in delayed sexual maturity.

Sorenson et al. (1959) reported results utilizing early nutritional levels of 60,100 and 140 percent of Morrison's recommended levels for growing dairy heifers. The groups exhibited first detected estrus at average ages of $72.0,49.1$ and 37.4 weeks, respectively. However estrus cycles occurred with about equal regularity thereafter.

In a study by Swanson (1960), which was similar to his earlier work, seven pairs of identical twin dairy heifers were separated at ages varying from 3 to 12 months. One of each palr was fed a normal ration while the other was fed concentrates at a very high level to first calving. Thereafter the heifers were fed alike at recommended levels. The fattened heifers averaged 899 compared to 683 pounds for the normal fed heifers. Further, fattened helfers lost about 143 pounds at calving compared to 50 pounds for the normal fed heifers. Nine months postpartum, the fattened heifers lacked 18 pounds of regaining their precalving weight while normal fed heifers weighted 142 pounds more than at precalving. 
Holloway and Totusek (1972) evaluated levels of early nutrition on subsequent productivity. Using 203 head of Angus and Hereford females in the springs of 1963 through 1966, varying nutritional levels were established. Low, medium and high levels were accomplished by weaning at 140 days of age, weaning at 240 days of age, and creep feeding 240-day weaned females. Reproduction was evaluated after three calvings. Though significant differences were not detected, certain trends were indicated. Creep-fed 240-day weaned females had heavier calves at birth for the first calf crop, but there after no differences were detected. Also, creep-fed 240-day weaned dams weaned the lightest calves in each calf crop. Further, creep-fed 240-day weaned females gave birth to a higher percentage of calves but also fewer (lower percent) calves were weaned by the creep-fed 240-day weaned females. Calving percentages tended to be lowest for 140 day weaned dams.

\section{Milk Production}

Several studies have indicated that heifers that are allowed to get excessively fat very early in life may provide poorer maternal environments than heifers developed such that fattening does not occur.

Swanson and Spann (1954) reported results through two lactations of the previously mentioned trials involving Jersey twins fed such that some fattened excessively while others did not fatten. The fattened heifers failed to milk as long as or as much as normal-fed heifers. In the first lactation the former avaraged 767 pounds of milk and 27.2 pounds of fat in 106 days. The normal ones averaged 1345 pounds of milk and 53.5 pounds of fat in the same period. In the second lactation the fattened females averaged 768 pounds of milk and 68.9 pounds of fat in 
in 68 days while the normal-fed females averaged in the same time 1437 pounds of milk and 56.5 pounds of fat. A similar study with rats was conducted in which lactation was estimated by the growth of equalized litters (11 young per 1itter). Rats raised by ad 1ib. feeding raised only 59 percent of their young to 21 days with an average litter gain of 136 grams. Rats fed 80 percent of ad lib. to parturition raised 98 percent to 21 days with an average litter galn of 235 grams.

In the previously mentioned Hansson (1956) study wherein Ayshire X Red Pied Swedish twin heifers were fed varying nutritional levels from one month to 25 months of age, the average fat-corrected-milk (FCM) yields for the first and all lactations were as follows:

TABLE I

LACTATION INFORMATION FOR DAIRY AND DUAL PURPOSE CATTLE*

\begin{tabular}{lccccc}
\hline & \multicolumn{5}{c}{ Rearing Intensities } \\
\cline { 2 - 6 } Lactations & 60 & 80 & $\mathrm{~N}$ & 120 & 140 \\
\hline F1rst & 3,117 & 3,145 & 3,016 & 2,866 & 2,573 \\
A11 & 3,328 & 3,244 & 3,119 & 2,908 & 2,635 \\
\hline * From Hansson (1956) & & & &
\end{tabular}

It was suggested that animals reared on low levels of nutrition had more efficient feed utilization during the rearing period. However, another relationship was mentioned wherein fat deposition in the mammary glands was increased, resulting in lowered milk production of females fed excessive amounts during rearing. Thus, an animal reared on high nutritional levels may produce less milk during the first lactation which may result in more fattening before the second calving. Therefore, milk 
production may also be reduced during later lactations.

Reid et al. (1959) used 102 Holstein females to estimate milk production and its relation to very early nutrition environment. Differing nutrition levels were established at birth and continued to first calving. The levels were 65, 100 and 140 percent of Morrison's standards to first calving. From first calving to second the groups were fed 118, 109 and 100 percent of recommended levels, respectively. After second calving, all were fed at recommended levels. Results suggested a trend for heifers reared on low levels to produce greater amounts of fat-corrected-milk than heifers on high levels during early development.

Swanson (1957) used seven identical twin heifers, one of each set fattened on a grain ration from 4 to 11 months while the other of each set was fed a normal growing ration. In the first lactation, the normals averaged 4362 pounds of FCM compared to 3669 pounds for fattened mates. Fattened females also milked slightly less in the second lactation. Udder sections from three pairs showed that the development of the lobule-alveolar system was inhibited in the fattened mates.

Swanson and Hinton (1964) utilized six pairs of Identical twin dairy heifers to evaluate normal and low levels of nutrition. One of each pair was fed a normal diet, including alfalfa-grass hay ad 11b. and concentrates up to one year of age. The other heifer of each pair was fed hay only, and from 4 to 24 months of age their consumption was restricted to 66 percent of the normal TDN resulting in body weights of about 25 percent below the normal-fed females. Their respective first lactation yields were (FCM) 4745 and 4117 pounds for the normal and restricted females. However, no differences were found in later lactations. 
Christian, Hauser and Chapmen (1965) also indicated that there may be a negative genetic or environmental relationship, or both, between weaning performance of the dam and the maternal environment she provides for her calf. Using 88 progeny of 52 Hereford cows (2, 3 and 4 years old), consistent negative associations $(P<.05)$ of dam's weaning weight with all measures of $\mathrm{milk}$ and butterfat production were seen while the calf's weaning weight was positively correlated with the cow's production.

Kress and Burfening (1972) Indicated different results. In this study a positive relation for 180-day weight with most probably producing ability (MPPA) for Hereford females was reported. The overall phenotypic correlations of 180-day weight and postweaning average daily gain with MPPA were 0.15 and -.10 , respectively. Koch and Clark (1955) reported observations supporting the idea that the maternal environment from birth to weaning may be negatively correlated, genetically, with weaning gain and score over the entire range of probably values. The theoretical composition of paternal and maternal half-sib correlations, the correlations between progeny and dam, and the offspring and sire were compared with observed values to estimate the influence of maternal environment.

Swanson (1967) stated that "from an economic as well as productive consideration, the optimum growth rate for dairy heifers will be obtained by moderate restriction of good-quality feed. Restriction during only the first 18 to 21 months of the growth period to 70 to 80 percent of presently used feeding standards can be practiced with no effect on lactation. Forcing rapid growth to achieve early calving is not an economical practice and cannot be expected to improve lactation 
efficiency." Swanson et al. (1967) also reported that slow growth rate (70 percent of normal) would not affect first lactation yield if prepartum supplemental feeding to improve body conditions were practiced. Also, overall TDN savings of 20 to 25 percent of standard may be possible. The prepartum supplementation perfod utilized was 12 weeks. Plum and Harris (1968) used a small number of Holstein females to estimate influences on maternal ability resulting when as calves (birth to weaning) some of the remales received milk in sufficlent quantities to obtain rapid early growth while other females received less milk and grew slower. A small group of Holstein cows were managed as beef females. Their calves were allowed to suckle until 7 months of age and the female calves were then saved to be compared to the female calves saved from Holstein cows managed as dafry females wherein the female calves were weaned from three to six months of age and preweaning were raised on restricted milk diets. These two classes of females were then compared through one lactation. First calving weights at 24 months of age for the "beef" and "dalry" raised females were 498 and $465 \mathrm{~kg}$., (nonsignificant) respectively. The first six months milk production were 2665 and $3617 \mathrm{~kg}$., respectively.

Mangus and Brinks (1969) utilized weaning weights of 2,286 calves to calculate MPPA for each of 610 beef cows. Product moment correlations of MPPA with actual weaning weight and weaning age were 0.03 and -.01 , respectively. "Results indicated that environmental factors reflecting high preweaning levels of nutrition had a detrimental effect upon subsequent cow productivity." Further, it was stated that "the low correlation between the heifers weaning weight and her subsequent productivity (0.142) indicates that the heifer's weaning weight is a 
poor criterion for selection to increase productivity."

Koch (1969) also reported that environment associated with growth of a dam may affect the phenotype of offspring through the maternal environment. These effects were estimated using 613 calf records in 115 grandam groups. The ratio of adjusted weaning weight of a calf to the average of 1 ts sex and year group was regressed on actual average gain from birth to weaning of the dam. The size of the regression obtained suggested a negative relation between environment affecting a dam's growth and the maternal environment provided the calf.

Boston (1973) used data obtalned over 14 calf crops from 680 Angus and 183 Hereford females. Records included weaning weights on 2,664 Angus and 634 Hereford calves. Simple linear regression estimates of heifer growth and subsequent cow productivity relationships were determined when the cow productive ages were two through ten years. Regression coefficients (calf record on cow record), at each age of dam, were somewhat higher for Hereford than for Angus females. Within Angus females, regression coefficients were about 0.15 to 0.20 when the cows were two to seven years old, and were very near zero when the cows were eight, nine and ten years old. Within Hereford females, regression coefflclents ranged from about 0.15 to 0.45 when the females were two to ten years old. Also, it was indicated that a female's own yearling welght may be slightly more indicative of her future productiveness than her six to seven month weaning weight.

Ewe Size and Productivity

Body size, often estimated by body welght, has often been a criterion for selection in domestic animals. Two basic factors contribute to body 
weight, body size as determined by skeletal and muscle development and also amount of fat covering. Since absolute body size is difficult to measure, body weight has been used extensively to estimate body size.

Guyer and Dyer (1954) reported a significant $(P<.05)$ partial correlation of 0.24 between gain to 63 days and fall yearling weight of the dams, holding number of lambs constant. Shelton (1959) studied 20 years data on Ramboulllet ewes and reported that the lifetime production followed a curvelinear relationshlp with the yearling weights of the ewes. The ewes with yearling weights between 100 and 115 pounds were found to produce more pounds of lamb in their life than ewes with yearling welghts over 115 or under 100 pounds.

Milk production of the ewe has been reported by some workers to be assoclated with body weight of the ewe (Burris and Baugus, 1955; Owen, 1957). Ray and Smith (1966) reported results based on 962 birth and 805 weaning weights. Indications were that the body weight of ewes was highly associated with weaning weight of the lambs and to a lesser degree the birth weights of the lambs. As the body weight of the ewe increased there was an increase in weaning weight of the lamb. An increase of one $\mathrm{kg}$. of ewes body weight resulted in a $0.1 \mathrm{~kg}$. increase in lamb weaning weight. However, lamb birth weight itself was not utilized in their analyses. Harrington (1963) indicated that ewe body weight was not closely related to lamb growth from birth to 70 days of age if sex, type of rearing, age of dam and breed of sire were included in the model before ewe body weight.

Nichols and Whiteman (1966) utilized records of 164 ewes (80 Rambouillet; 84 Rambouillet X Panama) to evaluate ewe size. When average lifetime ewe weight was adjusted to a constant condition score, 
positive correlations of 0.14 (total number of lambs born), 0.09 (total number of lambs raised), 0.24 (average 70-day lamb welght), and 0.28 (average lamb gain from 70 to 140 days of age) were determined. However, only the correlations involving average 70-day lamb weight and average lamb gain from 70 to 140 days were significant at probability levels of 0.05 and 0.01 , respectively. Also, average lifetime condition score was negatively and nonsignificantly correlated with measures of lifetime production.

Shelton and Menzies (1968a) summarized 36 years of data on the Ramboulllet flock at Sonora, Texas with the results presented in Table II for genetic correlations between varlous traits.

TABLE II

GENETIC CORRELATIONS AMONG TRAITS FOR RAMBOUILLET EWES*

\begin{tabular}{lcc}
\hline & Weaning Wt. & Yearling Wt. \\
\hline Yr. wt. & .6354 & \\
Mature weight & & .4671 \\
No. lambs born & -.0337 & .1828 \\
No. lambs raised & -.1137 & .1122 \\
Total lamb prod. & -.1118 & .1254 \\
\hline From Shelton and Menzies (1968a) &
\end{tabular}

The authors concluded that $1 \mathrm{t}$ may be best to sell milk-fat lambs and keep replacements from those that develop more slowly, but which have the potential to reach adequate mature size.

Ercanbrack and Price (1972) used 807 lambs out of Ramboulllet, Targhee and Columbia to construct selection indices to maximize weaning weight (120 days) and postweaning gain. In selection for improved 
weaning weight, little was gained by selecting on the basis of any traits other than weaning weight itself. Also, when yearling weight was of primary interest, selection on yearling weight alone resulted in near maximum progress per generation. For both weaning and yearling weights, selection indices including birth weight and/or any monthly weights did not greatly improve selection over and above selection for the specific traits of interest. Maximum postweaning gain per generation was achieved when birth weight, weaning weight and October weight (April born lambs) comprised the index.

Heritability Estimates of Body Weights

Heritability estimates of birth and weaning weight at 70 days of age should give indications in relation to the effectiveness of selection on various body weights. Also, certain types of heritability estimates of certain body weights can give some indications as to the meaningfulness of phenotypic correlation and regression coefficients between ewe and lamb traits.

In general, heritability estimates of birth weights have been in the low to moderate range while estimates of weaning weight at 70 days of age and gain from birth to 70 days have been low, as indicated in Table III.

Ewe Milk Production and Lamb Gain

Since accurately estimating ewe milk production is often a laborious task, studies reporting results relative to estimates of milk production on large numbers of ewes are limited. However, using 70 Merino ewes, Bonsma (1939) reported a correlation of 0.88 relative to lamb gain and ewe milk production for the first two weeks of lactation. 
TABLE III

HERITABILITY ESTIMATES OF BIRTH WEIGHT AND SUBSEOUENT GAIN BASED ON VARIOUS BREEDS OF SHEEP*

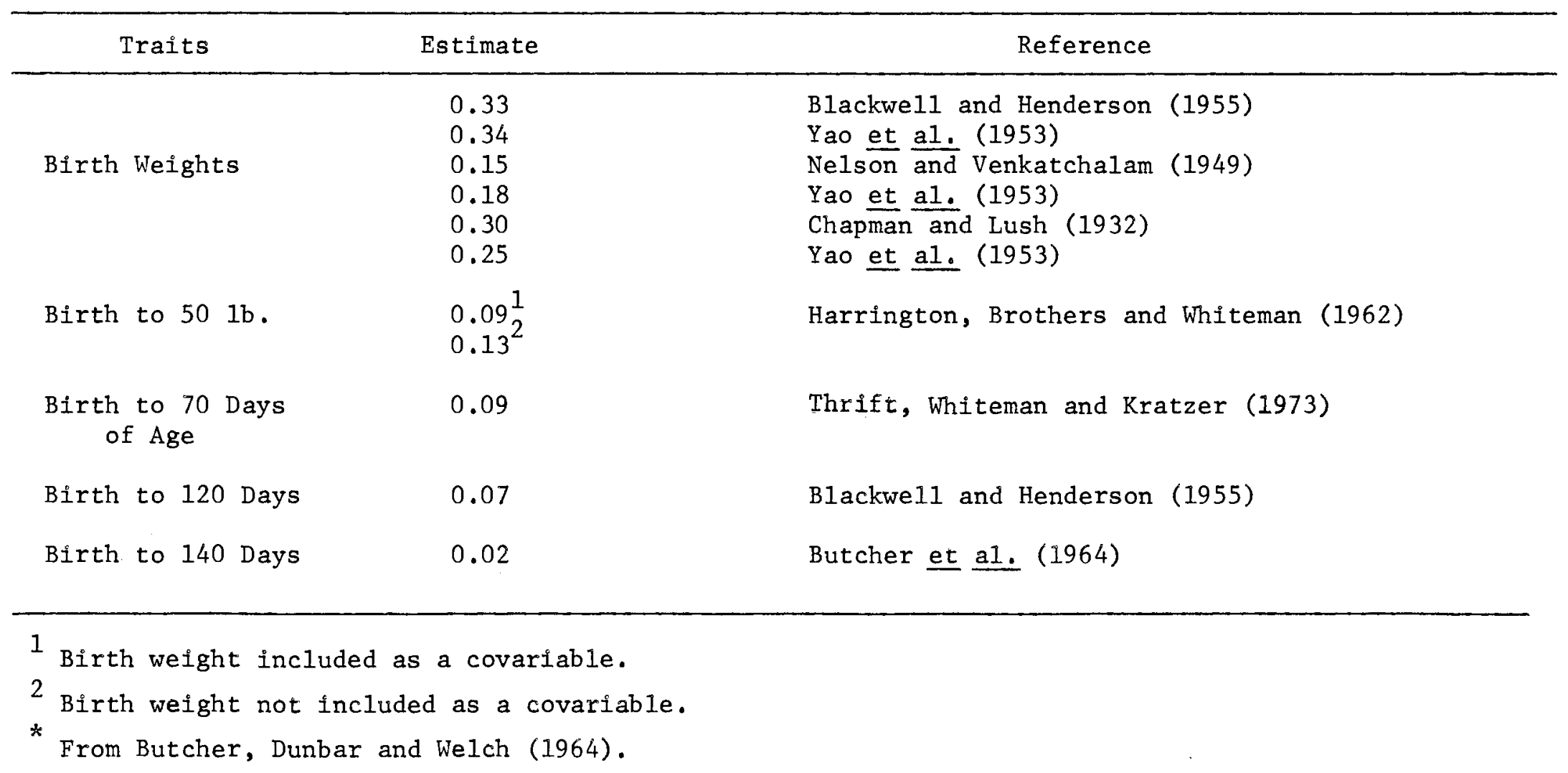


As lactation progressed, correlation values decreased. Relative to weeks two through five, the correlation was 0.78 while for weeks six through eight, the correlation was 0.51 and was 0.39 for weeks nine through eleven. Over the entire eleven week lactation period, the correlation was 0.81 relative to ewe milk production and lamb gain. Further, Shrewsbury (1943) reported a correlation of 0.89 between the gain of single-reared lambs and cumulative milk production to eight weeks of age. Whiting, Slen and Bezeau (1952) using 40 mature fine-wool ewes, reported a correlation of 0.63 between seven week lamb welght and average daily milk production. Burris and Baugus (1955), using 18 mature Hampshire ewes, reported correlations of 0.80 to 0.90 between lamb gain and ewe milk production.

Wallace (1948) was able to account for 96 percent of the variation in 112 day weight of 23 fine-wool lambs by differences in milk consumed plus supplemental feed. Owen (1957) used 181 Hill sheep rearing single lambs, reported correlations of 0.78 to 0.87 between lamb gain to two weeks of age and milk production. Correlations decreased to 0.68 to 0.73 when the period birth to ten weeks was considered. Harrington (1963) reported correlations between lamb net welght gain from two weeks through ten weeks with cumulative milk production ranging from 0.74 to 0.81. This would indicate that from 55 to 67 percent of the variation in lamb net gain through ten weeks was accounted for by the milk production variation. These estimates were accomplished over a two year period using 141 Dorset $X$ Western crossbred ewes with about $2 / 3$ suckling singles and the remainder suckling twins.

Barnicoat (1956) used Romney ewes (200 ewes) and reported that ewes rearing twins produced about 33 percent more milk than ewes with singies. 
Unpublished data from research conducted at the Fort Reno Livestock Research Station Indicated that when milk consumption was not considered (birth welght was considered), differences in 70-day weights of single versus twin-reared lambs was about 1.5 to 2.9 pounds. Further, when nelther milk consumption or lamb birth welght was considered, differences In 70-day weights of single versus twin-reared lambs was about 9.5 pounds.

Ewe Performance Vs Offspring Performance

Reports of phenotypic correlations involving sheep are quite limited. However, some herltability studies give an indication in relation to the size of correlations between dam and offspring. Plrchner (1969) Indicated that the correlation of offopring with dam or the Intrasire regression of offopring on dam methods of estimating herftability could be used to estimate the phenotypic correlations between dam and offspring traits. Dividing the herltabllity estimate by two should give an estimate of the correlation. Utilizing this method of estimation, it would seem that the correlation between a ewe's birth welght and the average birth welght of all her lambs would be in the range of 0.06 to 0.20 using the heritability estimates reported by Blackwell and Henderson (1955), Yao et al. (1953), Chapman and Lush (1932). Using the heritability estimates of weaning welght reported by Blackwell and Henderson (1955), Butcher et al. (1964), Harrington et al. (1962), estimated correlations between 0.00 and 0.08 for a ewe's own weaning welght and the weaning welght of her lambs result. Butcher et al. (1964) used Corrledale $(N=272)$, Hampshire $(N=209)$, and Southdown $(N=211)$ ewes to estimate the herftabllities (Intra-sire 
regression of offspring on dam) of birth and 140-day weights and also to estimate phenotypic correlations between dam and offspring traits. The estimated heritability of birth weight was $0.07,0.12$ and 0.16 , respectively, for the breeds involved while the estimates for 140-day weight were $0.03,-.06,0.08$, respectively. Phenotypic correlations ranged from -.04 (Southdown) to -.11 (Corriedale) for ewe and lamb birth weights. The range of the correlations between dams' 140-day weight and the 140-day weight of her lambs was -.03 (Hampshire) to 0.04 (Southdown). Thus in most cases, phenotypic correlations between the birth weight of the ewe and that of her lambs were quite small as were the phenotypic correlations between ewe and lamb weaning weights.

\section{Twin Vs. Single-Born Dams}

It has been established in numerous studies that type of birth (single or twin) is associated with differences in lamb birth weighes and subsequent growth at least through about 100 to 120 days. In general, twin-born lambs will be smaller at birth and gain somewhat slower to about 120 days (Thrift and Whiteman, 1969; Frederiksen, Price and Blackwell, 1967; Shelton and Campbe11, 1962; Brothers and Whiteman, 1960; Bogart et al., 1957; and Blackwell and Henderson, 1955). Dun and Grewal (1963) stated "the acceptability of any plan for increased fertility will therefore partly depend on the extent to which maternal handicap reduces the productive quality of sheep born in multiple births." However, most studies designed primarily to compare the performance of dams born as singles or twins have evaluated reproductive performance with little or no information relative to the growth of their lambs. 
Marsha11 and Potts (1921) evaluated 334 cases of lambing from services of five straight-bred rams, none of which were used less than three seasons, or on less than 20 ewes, and found no evidence of important variation in proportions of twins which was attributed to the sire. They also studied 458 cases of lambing which included only ewes that had dropped lambs at least three times with the following findings presented in Table IV.

TABLE IV

LAMBING OBSERVATIONS OF TWIN VS. SINGLE-BORN EWES ${ }^{*}$

\begin{tabular}{|c|c|c|c|c|}
\hline Ewe's Type of Birth & $\begin{array}{l}\text { No. of } \\
\text { Ewes }\end{array}$ & $\begin{array}{l}\text { No. of } \\
\text { Lambings }\end{array}$ & $\begin{array}{l}\% \text { Lambs } \\
\text { Dropped }\end{array}$ & Totals \\
\hline \multicolumn{5}{|l|}{ Born twins: } \\
\hline sires twins, dams twins & 3 & 12 & 133.0 & \\
\hline sires singles, dams twins & 18 & 84 & 142.9 & \\
\hline sires twins, dams singles & 3 & 12 & 116.6 & $140 \cdot 9$ \\
\hline sires singles, dams singles & 27 & 134 & 142.5 & \\
\hline \multicolumn{5}{|l|}{ Born singles: } \\
\hline sires twins, dams twins & 4 & 14 & 157.1 & \\
\hline sires singles, dams twins & 12 & 70 & 145.7 & 136.2 \\
\hline sires twins, dams singles & 4 & 21 & 109.5 & \\
\hline sires singles, dams singles & 24 & 111 & 132.7 & \\
\hline
\end{tabular}

*From Marshall and Potts (1921)

Even though twin-born ewes were 4.7 percent more prolific than singleborn dams, the difference was not significant. In reality, the highest record was from dams born as singles with both parents twins, and the second highest from single-born ewes by single sires from twin-born dams. Dun and Grewal (1963), utilizing twin and single-born Merino ewes, reported no real disadvantages in relation to the acceptability of twinborn ewes because of maternal handicaps. By 18 months of age twin-born 
ewes had almost overcome their maternal handicaps in body weight. Also, singles and twins did not differ in production of wool per unit of body area. Further, twin-birth was not assoclated with deterioration in the quality of 22 month old stock. They concluded that "management or breeding procedures aimed at increased fertility can be safely undertaken In the knowledge that twin-born ewes are productively superior to singles because of their higher fertility and their equivalent wool production per unit area of skin."

Shelton and Menzies (1968b) indicated that selection for twinning can be automatic in nature but under range conditions the opposite may more likely be true due to unknowingly favoring single-born lambs as replacements. Based on heritability estimates of about 12 percent, theoretically 17 generations of using only twin-born progeny on one side of the pedigree would be required to convert a flock to one in which multiples would be typical. They further suggested that in selection, twin-born lambs out of young ewes or those under less favorable conditions should be favored.

Breifly, this literature review indicates that early rearing Intensity of both beef and dairy heifers has much influence on early growth rate, but mature cow size and conformation are only slightly affected. Further, the many beef and dalry cattle reports suggest that cows that become excessively fat very early in life subsequently produce less milk than cows developed such that excessive fattening was avoided. Relative to sheep, few reports are available concerning the possible negative relationship between early ewe lamb nutrition level and subsequent milking ability. However, simple phenotypic correlations reported between a ewe's own performance very early in life and the growth 
performance of her lambs, In general, have been quite low ( -.15 to 0.15$)$. Further, heritability estimates of lamb gain from birth to about 70 days of age reported were also quite low with most being 0.10 or less. It has also been established through numerous studies that singlereared ewes are normally much heavier at weaning than twin-reared ewes. However, limited reports indlcate that the relationship between early ewe size (70 to 150 days) and mature body size is quite low. Further, limited reports suggest no real disadvantages in relation to the reproductive acceptability of twin born and reared ewes because of maternal handicaps. 


\section{CHAPTER III}

MATERIALS AND METHODS

During the fall seasons of $1956,1957,1958,1959,1960,1962$ and 1964, varying numbers of ewe lambs of Dorset $X$ Western breeding were raised from the lambs produced by the existing fine wool ewes at the Fort Reno Livestock Research Station at El Reno, Oklahoma, to be used as replacements in the ewe flock. These ewes were saved to be used in a long term study (project 908) designed to compare the life time productive and reproductive performances of "Western" ewes, typically used by Oklahoma sheep producers, and Dorset $\mathrm{X}$ Western crossbred ewes. Thus the dams utilized for this study were sired by "typical" Dorset rams obtained from various pure bred breeders in Oklahoma and Southern Kansas. In purchasing these "typical" Dorset rams, effort was made to avoid obtaining very inferior or very superior quality rams. Thus, the sires of the dams used in this study were considered "typical" of the Dorset rams available to sheepmen in the Southern Great Plains area. Even though the dams used for this study were involved in a research project not specifically designed to evaluate the problem of concern in this thesis study, the dams available were of such breeding that the relationship of interest in this study could be evaluated. Further, the dams and their offspring were managed (described later) throughout their lives such that the relationship of interest could be evaluated. 
In each year, these raised ewe lambs were usually the first openfaced ewe lambs to reach a weight of 80 to 85 pounds. The breeding of the ewes in 1956, 1957 and 1958 was $\frac{1}{2}$ Dorset X $\frac{1}{2}$ Rambouillet and 4/8 Dorset X $3 / 8$ Rambouillet X 1/8 Panama (approximately equal numbers of each type of breeding each year). In 1959, 1960, 1962 and 1964, all ewes raised were $\frac{1}{2}$ Dorset $X \frac{1}{2}$ Ramboulllet. Ewes that failed to lamb at either of the first two opportunities or ewes that gave birth to triplets were not considered in this study.

\section{Management of the Raised Ewes from Birth \\ to their First Lambing}

All of the ewes utilized in this study were born between October 10 and November 25 each year. As the ewes were born, the following information was obtained: (1) Lambing date; (2) Birth weight to the nearest one-tenth pound and (3) Type of birth (single or twin). Beginning at about two weeks of age, the lambs along with their dams, were allowed to graze wheat pasture and the lambs had access to a creep (free-choice) feed consisting of 63 percent cracked milo, 5 percent molasses and 32 percent chopped alfalfa hay. As the lambs reached about 70 days of age, weaning was accomplished by removing their dams from the wheat pasture lamb feeding area. The lambs were allowed access to the wheat pasture and creep until late March. During each lambing season the lambs were weighed every two weeks from about 40 days of age until they reached market weight. Thus females selected as replacements could be characterized in relation to birth weight, growth from birth to weaning at 70 days, and 70-day weight. At approximately $80-85$ pounds, ewes selected as replacements were taken from the creep area and thereafter were maintained 
on pasture and supplemental feed as needed to attain desired growth and development.

Beginning about August 20 and continuing through September 20 each year, these replacement ewes were exposed to fertile rams at which time they were approximately ten months of age. The ewe lambs that conceived during this period lambed in January and February of the following year at about 15 months of age. The ewe lambs that did not concelve at the first breeding were again exposed to fertile rams from May 20 to July 1 at about 19 months of age. The ewes that conceived to their first exposure to rams in the previous August and September had their lambs weaned from them early enough in the spring so that they were also exposed to fertile rams in May and June. Thus some of the ewes comprising this study lambed first at about 15 months of age while others lambed first at 24 months of age. Within each of these classifications, some ewes were single-reared and some were twin-reared. Total numbers of ewes and their distribution by subclass utilized for this study are presented in Table $V$.

Standard Flock Management Practices

Each year of their productive lives the ewes and their lambs were exposed to the following management practices:

1. All ewes were sheared about one week (May 8 - May 15) before spring breeding began.

2. After the ewes were shorn, they were individually weighed and were scored for degree of fatness (condition). They were also paint branded with their individual numbers for Identification purposes. Also, the ewes were paint branded to indicate a particular breeding allottment. 
TABLE V

OBSERVATION MATRIX: NUMBER OF EWES UTILIZED (CLASSIFIED BY YEAR OF BIRTH, AGE AT FIRST LAMBING AND TYPE OF REARING)

\begin{tabular}{|c|c|c|c|c|c|c|c|c|c|c|c|c|}
\hline & Tota1 & 1956 & 1957 & 1958 & 1959 & 1960 & 1962 & 1964 & $\begin{array}{r}\text { Single- } \\
\text { Reared }\end{array}$ & $\begin{array}{l}\text { Twin- } \\
\text { Reared }\end{array}$ & $\begin{array}{l}\text { Lambed } \\
1 \mathrm{st} \text { at } \\
15 \mathrm{mo} \text {. }\end{array}$ & $\begin{array}{l}\text { Lambed } \\
\text { lst at } \\
24 \text { mo. }\end{array}$ \\
\hline Total & 240 & 36 & 38 & 38 & 51 & 36 & 19 & 22 & 129 & 111 & 162 & 78 \\
\hline $\begin{array}{l}1956 \\
1957 \\
1958 \\
1959 \\
1960 \\
1962 \\
1964 \\
\text { Single- } \\
\text { Reared } \\
\text { Twin- } \\
\text { Reared } \\
\text { Lambed 1st } \\
\text { at 15 mo. } \\
\text { Lambed 1st } \\
\text { at } 24 \text { mo. }\end{array}$ & & 36 & $\begin{array}{r}0 \\
38\end{array}$ & $\begin{array}{r}0 \\
0 \\
38\end{array}$ & $\begin{array}{r}0 \\
0 \\
0 \\
51\end{array}$ & $\begin{array}{r}0 \\
0 \\
0 \\
0 \\
36\end{array}$ & $\begin{array}{r}0 \\
0 \\
0 \\
0 \\
0 \\
19\end{array}$ & $\begin{array}{r}0 \\
0 \\
0 \\
0 \\
0 \\
0 \\
22\end{array}$ & $\begin{array}{r}25 \\
26 \\
26 \\
23 \\
12 \\
10 \\
7 \\
129\end{array}$ & $\begin{array}{r}11 \\
12 \\
12 \\
28 \\
24 \\
9 \\
15 \\
0 \\
111\end{array}$ & $\begin{array}{c}11 \\
21 \\
28 \\
38 \\
28 \\
14 \\
22 \\
90 \\
72 \\
162\end{array}$ & $\begin{array}{r}25 \\
17 \\
10 \\
13 \\
8 \\
5 \\
0 \\
\\
39 \\
39 \\
\\
\\
0 \\
\end{array}$ \\
\hline
\end{tabular}


3. The ewes were randomly assigned to these breeding allottments on the basis of their age, their breeding and their past performance. The ewes were moved to small breeding pastures and breeding began. Each breeding group (allottment) numbered from 32 to 50 ewes. The ewes in each breeding group were exposed to fertile blackface (Hampshire or Suffolk) and whiteface (Dorset)-.rams; with breed of ram being rotated nightly within each of the breeding groups.

4. At the end of the breeding season, all ewes were maintained again as one flock on mixed grass pasture.

5. Beginning about August 20 and continuing for 30 days each year, all ewes were exposed to fertile blackfaced and whitefaced rams to allow ewes not conceiving in the spring a chance to lamb in January or February. The breeding and lambing schedules are illustrated in Figure 1.

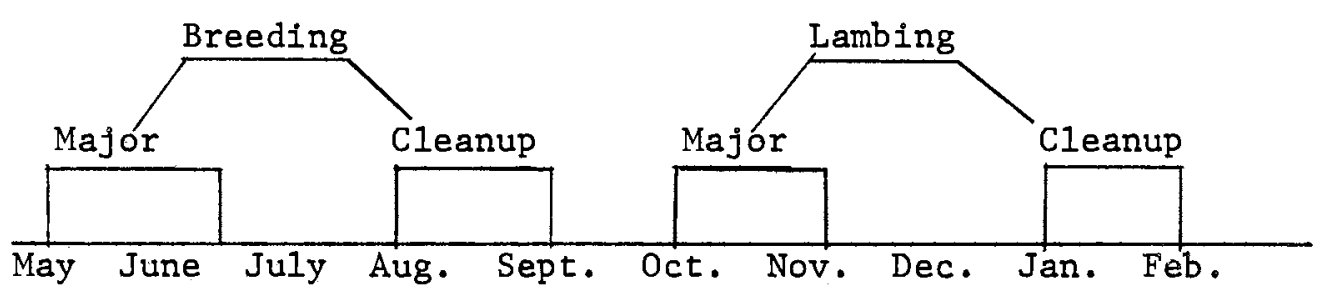

Figure 1.

6. About six weeks before lambing, the ewes were fed a supplemental grain (cracked milo) ration beginning with about one-half pound per head per day and gradually increasing until at lambing the amount per ewe was one pound.

7. All ewes were tagged about two weeks before fall lambing was scheduled to begin. 
8. The ewes were lambed at a central lambing barn and remained there until their lamb(s) were about 10 days to two weeks of age. Birth weights were recorded within 12 hours of birth and all lambs were identified by metal ear tags and paint brands. Lambs were docked at about two days of age and castrated by 30 days of age.

9. At about 10 days to two weeks of age, the lambs along with their dams were moved to the lamb feeding area where both ewes and lambs had access to what pasture. Also, all lambs had access to the previously mentioned creep-feed free cholce. Twin and single-rearing ewes were fed separately so that twin-rearing ewes could be fed additional grain. The ewe supplement consisted of cracked milo and about one pound of alfalfa or grass hay per ewe per day for about six to elght weeks after lambing.

10. The dams were removed from their lambs when the lambs were about 70 days of age and were then maintained on dry native grass and protein supplement until the next breeding season. The lambs remained on creep feed and wheat pasture until late March at which time the lambs were confined to dry lot with access to the creep feed until lambs to be marketed welghed about 95 pounds. The lambs were weighed on a bi-weekly basis from 40 days of age until sold at 95 pounds. This schedule provided a means of determining rates of gain from birth to 70 days, 70-day welghts, and rates of gain from 70 days to market. The 70-day weights were calculated by the linear interpolation method as described by Taylor and Hazel (1955).

Ewes in this study were not culled for any reasons other than seriously deteriorated teeth and extremely poor condition. However, when ewes were subjected to greatly different management than has been described or exposed to different breeding and lambing schedules than 
have been described their records were not used further in relation to this study. As a result some ewe records include eight lambings in this study, some seven, some six and so on until of 22 ewes born in 1964, only their first lambing records were used or included in this study. This study utilized lambing performance records of the ewes up to and including the age of 96 months. Lambing performances of ewes older than 96 months were eliminated as performance became somewhat erratic, and also since 1 t is normal in most commercial sheep operations to cull ewes over 96 months of age. The numbers of lambs produced which were utilized in this study are presented in Table VI.

TABLE VI

NUMBERS OF LAMBS UTILIZED BY EWE CLASSES

\begin{tabular}{|c|c|c|c|c|}
\hline $\begin{array}{l}\text { Year of } \\
\text { Ewe Birth }\end{array}$ & $\begin{array}{l}\text { Single-reared } \\
\text { dams lambing } \\
\text { lst at } 15 \mathrm{mo} \text {. }\end{array}$ & $\begin{array}{l}\text { Single-reared } \\
\text { dams lambing } \\
\text { lst at } 24 \mathrm{mo} \text {. }\end{array}$ & $\begin{array}{l}\text { Twin-reared } \\
\text { dams lambing } \\
\text { lst at } 15 \mathrm{mo} \text {. }\end{array}$ & $\begin{array}{l}\text { Twin-reared } \\
\text { dams lambing } \\
\text { lst at } 24 \mathrm{mo} .\end{array}$ \\
\hline Total & 676 & 308 & 391 & 238 \\
\hline $1956^{a}$ & 127 & 136 & 13 & 93 \\
\hline $1957^{a}$ & 146 & 91 & 73 & 52 \\
\hline $1958^{a}$ & 197 & 57 & 86 & 30 \\
\hline $1959^{\mathrm{a}}$ & 80 & 8 & 88 & 32 \\
\hline $1960^{a}$ & 86 & 8 & 79 & 18 \\
\hline $1962^{a}$ & 30 & 8 & 30 & 13 \\
\hline $1964^{a}$ & 10 & 0 & 22 & 0 \\
\hline
\end{tabular}

$a_{\text {Year dam was born and saved }}$ 
Statistical Analyses

Initial Lamb Data Adjustments

A11 lamb data (lambs born to the 240 ewes in this study) were initially adjusted for differences in sex, breed of sire, type of birth and type of rearing (age of dam was not adjusted for since analyses were on a within age of dam basis). The variables studied and so adjusted were birth weight, rate of gain from birth to 70 days of age, 70-day weight, and rate of gain from 70 days of age to market at about 95 pounds. The various adjustment factors were determined by the Statistical Analysis System regression program using least squares procedures as described by Barr and Goodnight (1971). All adjustment factors (partial regression coefficients or $\hat{\beta}_{i}$ values) were calculated by combining all lamb records available to estimate the various $\hat{\beta}_{1}$ values. Adjustment factors were determined in this manner assuming that the adjustment factors would not be different for lambs born to the four groups of ewes in this study, which were: single-reared that lambed first at 15 months, single-reared that lambed first at 24 months, twinreared that lambed first at 15 months, and twin-reared that lambed first at 24 months. These assumptions were made based on work by Harrington (1963) which indicated that no interactions of importance existed between year and sex, year and breed of sire, year and type of birth and rearing. Further, previous work by Gould and Whiteman (1971) indicated adjustment factors for spring and fall-born lambs were essentially equal.

The restrictions placed on the various models were that within each classification variable (sex, type of birth, breed of sire, and type of birth and rearing) the deviations or $\hat{\beta}_{i}$ values would sum to zero. Thus 
each lamb was adjusted to the average of the two sexes, the average of the breeds of sire, the average of the two types of birth and the average of the three types of birth and rearing.

The birth weight model was: $Y_{i j k}=\mu+S_{i}+B_{j}+T_{k}+e_{i j k}$

The model for ADG birth to 70-days, 70-day weight, ADG 70 days to market was: $Y_{i f m}=\mu+S_{i}+B_{f}+F_{m}+e_{i j m}$

Where,

$Y_{i j k}$ is an individual observation of a lamb birth weight。

$Y_{i j m}$ is either an individual observation of a lamb rate of gain from birth to 70 days of age, an individual observation of a lamb 70-day weight, or an individual observation of a lamb rate of gain from 70 days of age to market, respectively.

$\mu \quad$ is an effect common to every lamb for the trait being considered。

$S_{i}$ is an effect for the ith sex of lamb. $\left(S_{1}=\right.$ effect due to female, $S_{2}=$ effect due to male)

$B_{f}$ is an effect for the $j$ th breed of sire (lamb face color) of a lamb。 $\left(B_{1}\right.$ - effect due to blackface, $B_{2}=$ effect due to whiteface)

$\mathrm{T}_{\mathrm{k}}$ is an effect for the kth type of birth of a lamb. $\left(t_{1}=\right.$ effect due to single-born, $t_{2}$ = effect due to twin-born)

$\mathrm{F}_{\mathrm{m}}$ is an effect of the mth type of birth and rearing of a lamb. $\left(F_{1}=\right.$ effect due to single, single; $F_{2}=$ effect due to twin, single; $F_{3}$ = effect due to twin, twin)

$e_{i j k}$ is the failure of the birth weight model to correctly estimate a lamb birth weight. 
$e_{1 j m}$ is the fallure of the various growth models to correctly
estimate the characteristic of interest.

The correction ( $\hat{\beta}_{1}$ values) factors determined agreed quite closely with those of Gould and Whiteman (1971), Harrington (1963), S1dwell and Grandstaff (1949) and also with unpublished results from other work conducted at the Fort Reno Livestock Station at E1 Reno, Oklahoma. The $\hat{B}_{1}$ values determined in this study appear in Table VII.

To facilitate correlation analyses, after adjusting the lamb data, all twin records were converted to single records for birth weight, 70-day welght, ADG from birth to 70 days of age and ADG from 70 days of age to market by averaging the approprlate values for each set of twins and using the average as the value for the partlcular set of twins. This avolded having two lamb records for a ewe when she gave birth to twins. The dam data were not adjusted for year of birth or age of dam at any lambing because all analyses were done on a within year of dam saved basis and further on a within age of dam basis.

\author{
Determining the Relationship Between \\ Early Ewe Lamb Nutrition And \\ Subsequent Milking Ability
}

Relationships Between Ewes and Their Offspring

The four groups of ewes were compared by determining the relationshlps between the ewe's birth welght and the birth welghts of her various lambs, the ewe's average daily gain from birth to 70 days of age and her lambs' galns from birth to 70 days, the ewe's 70 -day weight and the 70-day welght of her varlous lambs, the ewe's 70-day welght or average 
TABLE VII

MEAN BIRTH WEIGHTS, 70-DAY WEIGHTS, AVERAGE DAILY GAIN BIRTH TO 70 DAYS, AVERAGE DAILY GAIN 70 DAYS TO MARKET, AND ESTIMATES OF $\hat{\beta}_{1}$ OF ASSOCIATED VARIABLE

\begin{tabular}{|c|c|c|c|c|}
\hline Source & Birth Wt. ${ }^{a}$ & $\begin{array}{l}\text { ADG Birth } \\
\text { to } 70 \text { Days }^{2}\end{array}$ & $\begin{array}{l}\text { 70-Day } \\
\text { Wt. }{ }^{2} \\
\end{array}$ & $\begin{array}{l}\text { ADG } 70 \text { Days } \\
\text { to } \mathrm{Mkt} \text {. }\end{array}$ \\
\hline Mean $(\mu)$ & 8.90 & 0.61 & 51.59 & 0.53 \\
\hline \multicolumn{5}{|l|}{$\operatorname{Sex}: \hat{\beta}_{1}$} \\
\hline$\hat{\beta}_{11}:$ Female & -.3186 & -.0212 & -1.7093 & -.0278 \\
\hline$B_{12}:$ Male & 0.3186 & 0.0212 & 1.7093 & 0.0278 \\
\hline \multicolumn{5}{|l|}{$\underset{\hat{o}}{\text { Breed of Sire: } \hat{B}_{2}}$} \\
\hline${ }_{21}$ : Blackface & 0.3067 & 0.0313 & 2.3936 & 0.0329 \\
\hline$B_{22}$ : Whiteface & -.3067 & -.0313 & -2.3936 & -.0329 \\
\hline \multicolumn{5}{|l|}{ Type of Birth: $\hat{B}_{3}$} \\
\hline$\beta_{31}$ : Single & 0.7472 & & & \\
\hline$\hat{B}_{32}:$ Twin & -.7472 & & & \\
\hline \multicolumn{5}{|l|}{$\begin{array}{l}\text { Type of Birth } \\
\text { and Rearing: } \hat{\beta}_{4}\end{array}$} \\
\hline$\hat{B}_{41}: S S$ & & 0.0518 & 4.6960 & -.0098 \\
\hline$\hat{B}_{42}: \mathrm{TS}$ & & -.0160 & -1.5616 & 0.0059 \\
\hline$\hat{\beta}_{43}: \mathrm{TT}$ & & -.0358 & -3.1344 & 0.0039 \\
\hline
\end{tabular}

${ }^{a}$ All values presented in terms of pounds or pounds per day。 
daily gain from birth to 70 days and the gain from 70 days to market of her lambs. These relationships were estimated by calculating both correlation and regression coefficients for the various traits between the ewes and their lambs. These estimates of phenotypic relationships should allow evaluation of the association of preweaning nutrition level (estimated by preweaning growth) of the ewe lamb and her subsequent milking ability as estimated by the growth of her lambs from birth to 70 days. But it must be realized that in this type of analysis, confounding of direct additive genetic and maternal additive genetic components may occur. Willham (1963) explained the causal components of dam-offspring covartance as follows:

Cov. Dam-offspring $=\frac{1}{2}\left(G_{c}\right)+5 / 4 \operatorname{Cov}\left(G_{c} G_{m}\right)+\operatorname{Cov}\left(D_{c} D_{m}\right)+$

$$
\frac{1}{2} V\left(G_{m}\right)+\operatorname{Cov}\left(E_{c} E_{m}\right) \text { where, }
$$

$G_{C}=$ the direct additive genetic effect.

$G_{m}=$ the maternal additive genetic effect.

$D_{c}=$ the direct dominance genetic effect.

$\mathrm{D}_{\mathrm{m}}=$ the maternal dominance genetic effect.

$E_{c}=$ the direct environmental effect.

$E_{m}=$ the maternal environmental effect.

The relationships between the ewes and their lambs were estimated by evaluating the magnitude and sign of the simple phenotypic correlations for the various traits of interest. The data were further analyzed by simple linear regression of lamb traits on ewe traits. All correlation and regression techniques and various statistical tests involving the correlation and regression coefficients were accomplished as described by Snedecor and Cochran (1967). 
Blrth Welghts and Subsequent Galns of Lambs

Born to the Single and Twin-Reared Ewes

The varlous groups of ewes in this study were further compared by estimating the influence of type of rearing of the ewe (alngle or twin) and age of ewe at firgt lambing ( 15 months or 24 months) on the growth performance of their lambs. These comparisons should allow evaluation of the relationshlp between the early nutritional level of the ewe lambs and thelr subsequent milking abllitles relatively free of direct additive genet1c effects. These comparisons were made by means of least squares procedures using methods described by Barr and Goodnight (1971). Least squares constants were determined by including the four dam classificatIons mentioned above in the following model for lamb birth weight, ADG from birth to 70 days of age, 70-day welght, and ADG from 70 days to merket:

$Y_{1 j k}=\mu+A_{1}+B_{j}+e_{1 j k}$

Where,

$Y_{1 j k}$ is an Individual observation of elther a lamb blrth welght, or his ADG from birth to 70 days of age, or his 70 -day welght, or his ADG from 70 days of age to market.

$\mu \quad$ Is an effect common to all lambs for the trait under consideration.

$A_{1}$ Is an effect for the ith dam type of rearing of every lamb. $\left(A_{1}=\right.$ effect due to single, $A_{2}=$ effect due to twin)

$B_{f}$ is an effect for the $f$ th age of dam at first lambing of every lamb. $\left(B_{1}=\right.$ effect due to 15 months, $B_{2}=$ effect due to 24 months) 
$e_{i f k}$ is the fallure of the above model to estimate the lamb variable involved。

These analyses were done on a within year of dam birth basis, thus age of dam could not be considered in the models.

Analyzing the data in this manner, the following information was obtainable:

1. Estimate of the relationship between each associated variable (age of dam at first lambing and dam type of rearing) and the lamb trait under consideration. These estimates of relation should allow estimation of the influence of preweaning nutritional level of the ewe on her subsequent milking ability relatively free of additive genetic gaining ability of the lamb.

2. Least squares constants (partial regression coefficients or $\hat{B}_{1}$ values) which were estimates of the relationship between each particular associated variable and the trait under consideration.

3. Least squares means。

4. The standard error of each associated variable.

Comparisons of the performance of lambs born to the different groups of ewes were made on the basis of birth weight, rate of gain from birth to 70 days; 70 -day weight, and rate of gain from 70 days of age to merket. These comparisons were accomplished by calculating the differences between the least squares constants for each trait studies for the four groups of dams and determining statistical significance.

Standard errors of individual least squares estimates were calculated as follows:

$$
s_{\hat{\beta}_{i}}=\sqrt{c_{11} \hat{\sigma}^{2}}
$$


where $c_{1 i}$ is the diagonal inverse element corresponsing to $\hat{\beta}_{1}$ and $\hat{\sigma}^{2}$ is the residual mean square obtained from the approprlate analysis of variance. Tests for statistical sfgnificance of the difference between two constants were obtained by:

$$
t\left(\hat{\beta}_{i}-\hat{\beta}_{j}\right)=\frac{\hat{B}_{1}-\hat{\beta}_{j}}{\sqrt{\left(c_{i 1}+c_{j j}-2 c_{i j}\right)\left(\hat{\sigma}^{2}\right)}}
$$

where the denominator is also the standard error of the difference between estimates of $\hat{\beta}_{i}$ values.

$$
\begin{gathered}
\text { Analyses of Data to Estimate Repeatability } \\
\text { of the Various Lamb Traits }
\end{gathered}
$$

The growth (preweaning) performance of a lamb is estimated in this study by 70 -day weight and gain from birth to 70 days. The repeatability of these two traits are in reality measures or estimates of the consistency of performance of the dam. Thus the repeatability of the above traits allows another means of comparing single and twin-reared ewes through the growth performance of their lambs. The phenotype of a lamb is influenced through the genetic component including the maternal ability of the ewe as well as including additive, dominance and perhaps some epistatic effects common in lambs born to the same ewe, which comprise a sample half of the ewe's additive genotype for the trait in question.

When phenotype is thought of in terms of the (1) genotype plus (2) permanent environmental differences plus (3) temporary environmental differences, Cunningham and Henderson (1965) indicated the following: 


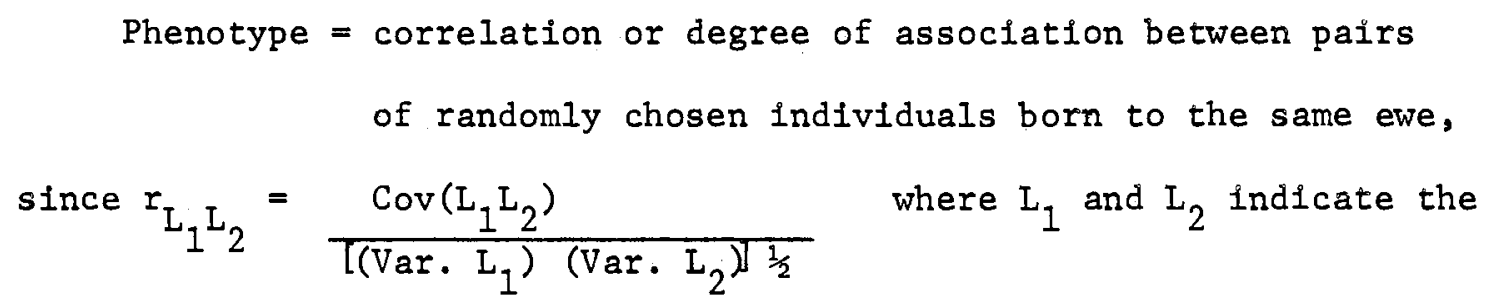
two lamb records of interest. If it is assumed that Var. $\mathrm{L}_{1}=\operatorname{Var} . \mathrm{L}_{2}$, then $r_{L_{1} I_{2}}=b_{L_{2} L_{1}}$. Also since $b_{L_{2} L_{1}}=\frac{\operatorname{Cov}\left(L_{1} L_{2}\right)}{\operatorname{Var} \cdot L_{1}}$, then this should equal Var. permanent and this in effect equals the (Var. permanent) (Var. temporary)

regression of a dependent trait (later record) on the independent trait (the earlier record).

This type of regression or correlation estimator of repeatability was indicated by Curnow (1961) to be unbiased and unaffected by selection based on earlier records. However, it should be remembered that a basic assumption in the estimation of repeatability from the regression of dependent on independent records is that the phenotypic variance of the records is the same for both groups involved. 
CHAPTER IV

\section{RESULTS AND DISCUSSION}

In general, research in the last several years has indicated that heifers that become too fat very early in life subsequently become poorer milking dams than heifers developed such that fattening was avoided. If this circumstance exists for ewes, then selection of faster growing ewe lambs (within breed) may result in poorer milking ewes. Since it has been suggested that 60 to 70 percent of the variation in lamb 70-day weight is associated with the milk consumption by the lamb (Harrington, 1963; Bradford, 1971), then slower gaining lambs may result from ewes that were themselves fast growing as lambs if the suggested negative relationship exists.

The ewes available for this study could allow insight in this matter. The data were handled in two basic ways to evaluate the relationship between early ewe lamb nutrition and subsequent milking ability (estimated by growth performance of offspring). First, phenotypic relationships between the growth of the ewes and of their lambs were estimated as a means of evaluating the overall association between early ewe lamb nutrition and subsequent milking ability. However, phenotypic damoffspring relationships may involve confounding of direct additive genetic and maternal additive genetic components. A second method of data handling was done to obtain an evaluation of the relationship between early ewe lamb nutrition and subsequent milking ability 
relatively free of the direct additive genetic effect. By simply comparing the birth weights and subsequent performances of lambs born to the single and twin-reared ewes, the relationship of interest could be evaluated free of the direct additive genetic component.

\section{Relationship Between Ewe Lamb Growth From Birth to 70 Days and the Growth of the Progeny}

If a negative relationship truly exists between early ewe lamb nutrition (estimated by her preweaning growth) and her subsequent milkIng ability (estimated by the growth of her progeny), then the phenotypic dam-lamb relationship should be very near zero or negative. Of primary interest were the phenotypic ewe-lamb relationships for birth weights and performance to 70 days of age. All correlations between each of the four groups of dams and their lambs were calculated first by pooling over year of dam birth. Simple linear regressions were also calculated and appear in Tables XXXI and XXXII of the Appendix. In almost all cases, the corresponding correlation and regression coefficients were the same in sign and were very similar in magnitude. This would suggest that the assumption of equal phenotypic varlances for the earlier and later records in question was basically correct.

\section{Birth Weight}

Though birth weight as such is not the primary trait of interest in this study, it must be considered since Harrington (1963) reported that each additional pound at birth is associated with three additional pounds when the lambs are 70 days old. 
The correlations between the ewe's birth weight and the birth weights of their lambs, for the four groups of ewes, are presented in Table XIV of the Appendix. These correlations, by age of dam, are further illustrated in Figure 2. In the left half of Figure 2 are the comparisons by age of dam for ewes that lambed first at 15 months of age while in the right half of the figure are comparisons for ewes that lambed first at 24 months of age. Only two of the 34 correlation coefficients plotted are significantly $(P<.05)$ different from zero. As is evident from Figure 2 differences in correlation values, at each age of dam, associated with age of dam at first lambing are not apparent since the correlation coefficients within age of dam at first lambing, for each age of dam, are very similar for the single and twin-reared ewes. The data were therefore pooled over age of dam at first lambing.

These correlation coefficients (pooled over age of ewe at first lambing) for the single and twin-reared ewes are presented in Table XVII of the Appendix and are further fllustrated in Figure 3. Once again, it is well to note that none of the 18 correlation coefficlents (for each age of dam) are significantly $(P<.05)$ different from zero. Further, since none of the correlations for each age of dam are significantly $(P<.05)$ different between the single and twin-reared dams, pocling over ewe type of rearing would seem valid.

These correlation coefficlents further pooled over ewe type of rearing are presented in Table VIII and are also illustrated in Figure 4. Referring to the plotted coefficients, it is apparent that at most ages of dams, the estimated phenotypic relationships between the ewes' birth weight and the birth weights of their lambs are slightly positive but none are significantly $(P<.05)$ different from zero. Also, even though 


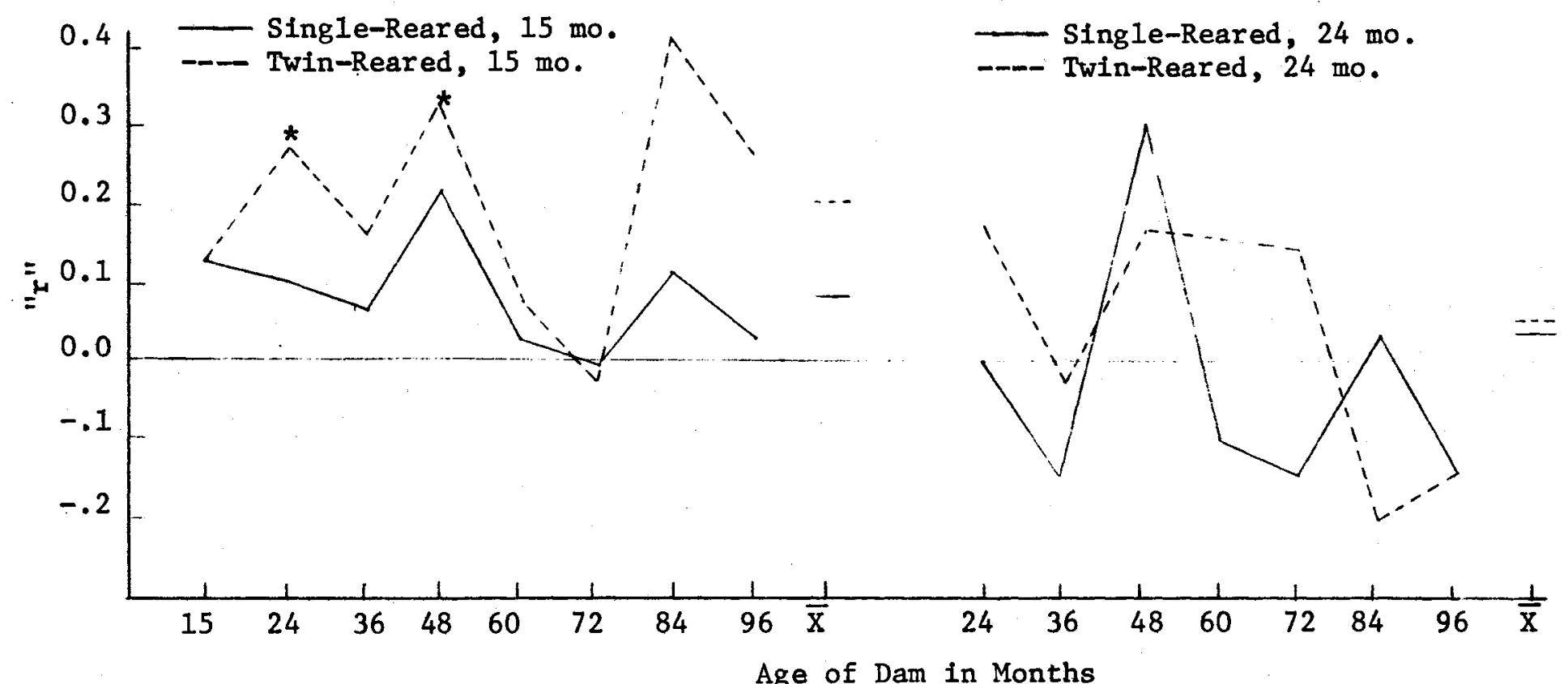

* Significantly $(P<.05)$ different from zero

Figure 2. Simple Phenotypic Correlations ( $r$ ) Between Ewe Birth Weight and Her Various Lamb Birth Weights Presented by Age of Dam 


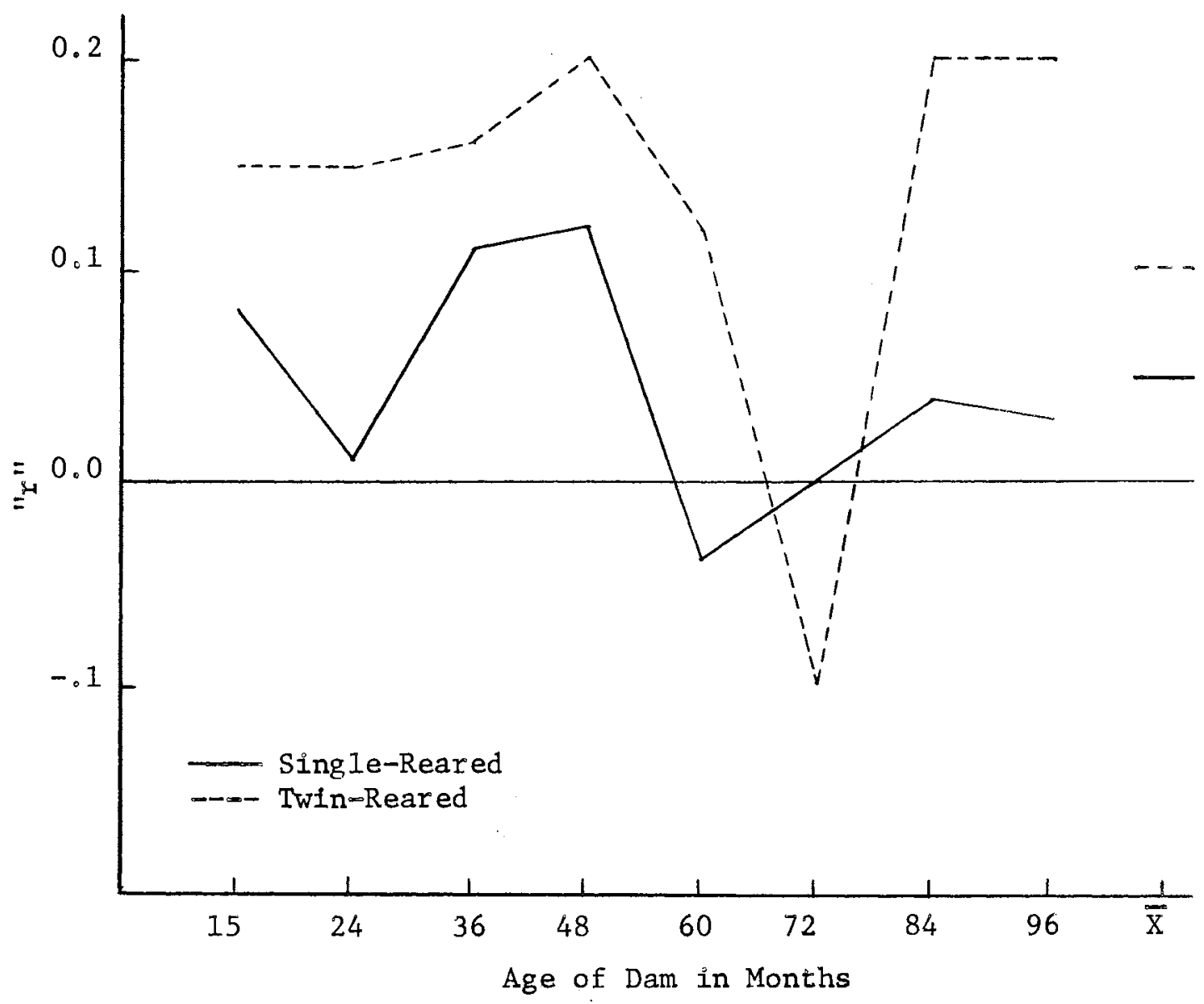

Figure 3. Simple Phenotypic Correlations ( $r$ ) Between Ewe Birth Welght and Her Varlous Lamb Birth Weights Pooled Over Age of Dam at First Lambing and Presented by Age of Dam 
TABLE VIII

SIMPLE PHENOTYPIC CORRELATION COEFFICIENTS BETWEEN EWE BIRTH WEIGHT AND HER VARIOUS

LAMB BIRTH WEIGHTS WITH THE DATA POOLED OVER AGE OF DAM AT

FIRST LAMBING AND OVER DAM TYPE OF REARING AND

PRESENTED BY AGE OF DAM

\begin{tabular}{c|ccccccccc}
\hline & \multicolumn{1}{c}{ Age of Dam in Months } \\
\cline { 2 - 9 } & 15 & 24 & 36 & 48 & 60 & 72 & 84 & $\begin{array}{c}\text { Avg. of } \\
\text { A11 Lambs }\end{array}$ \\
\hline \multirow{2}{*}{$\mathrm{N}$} & 162 & 211 & 205 & 171 & 114 & 107 & 99 & 77 & 240 \\
$\begin{array}{l}\text { Correlation } \\
\text { Coefficients }\end{array}$ & 0.08 & 0.05 & 0.11 & 0.13 & -.01 & -.02 & 0.12 & 0.15 & 0.10 \\
\hline
\end{tabular}




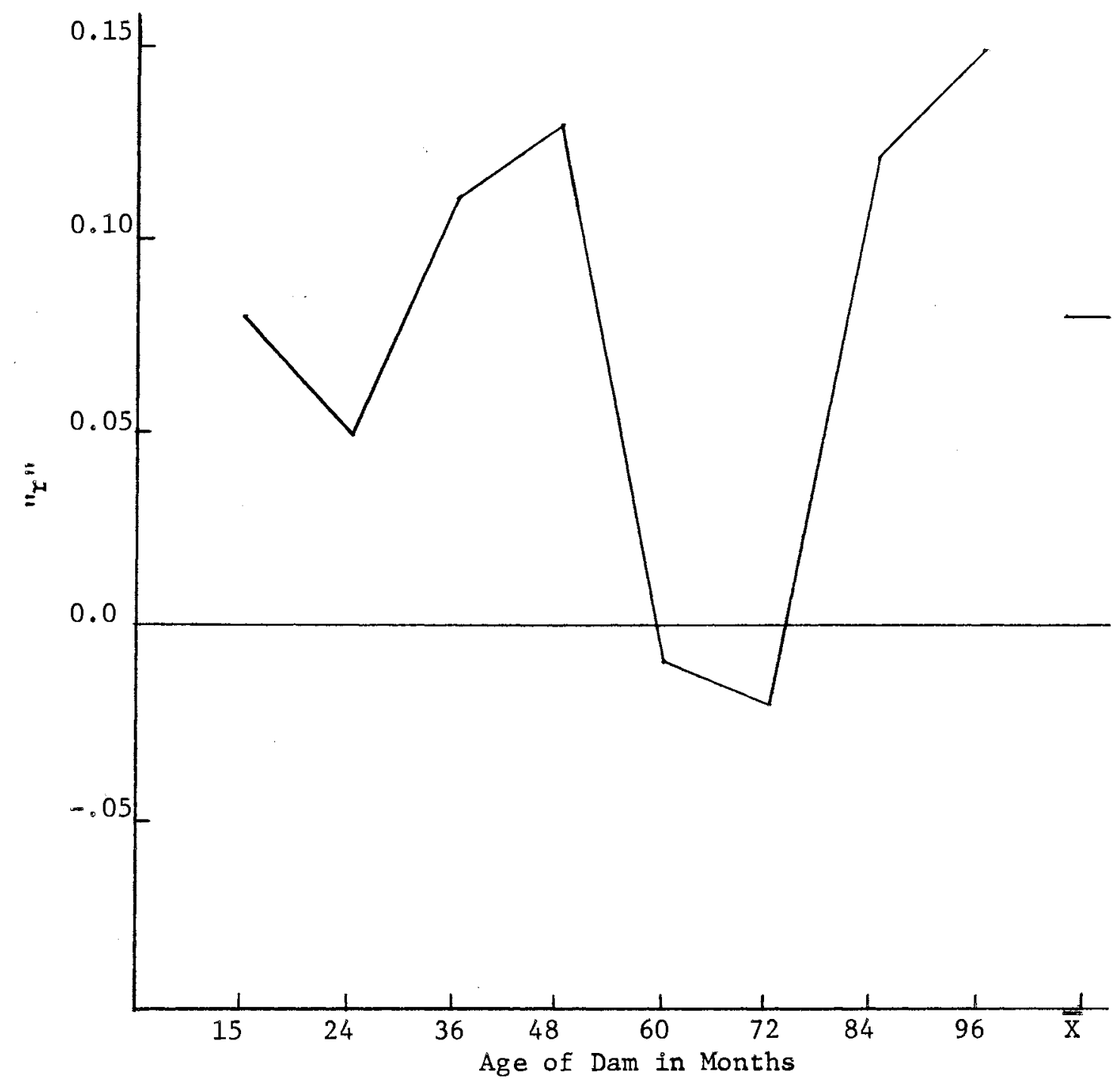

Figure 4. Simple Phenotypic Correlations $(r)$ Between Ewe Birth Weight and Her Varlous Lamb Birth Weights With the Data Pooled Over Age of Dam at First Lambing and Over Dam Type of Rearing and Presented by Age of Dar. 
the values of the correlations vary at the different ages of dams, definite increasing or decreasing (correlation coefficient values) trends over the various ages of dams are not evident. These results are in general agreement with the very small and nonsignificant values reported by Butcher et al. (1964) using Southdown (-.04) and Corriedale (-.11) ewes.

Gain From Birth to 70 Days of Age

The performance period of birth to 70 days of age is the primary period of interest in this study. If there is a negative relationship between very early ewe lamb nutrition and subsequent milking ability, then the estimated phenotypic relationships for this growth period should be very near zero or negative.

The correlation coefficients for each of the four groups of dams, by age of dam, are presented in Table XV of the Appendix and are further illustrated in Figure 5. On the left half of the figure are the coefficients, by age of dam, for the single and twin-reared ewes that lambed first at 15 months of age while on the right half are the correlations for the single and twin-reared ewes that lambed first at 24 months of age. None of the 36 correlation coefficients are significantly $(P<.05)$ different from zero. Also, none of the coefficients between the single and twin-reared ewes (within age of ewe at first lambing) for each age of dam are significantly $(P<.05)$ different from each other. The data were therefore pooled over age of ewe at first lambing. These correlation coefficients (pooled over age of ewe at first lambing) for the single and twin-reared ewes are presented in Table XVII of the Appendix and are further 1llustrated in Figure 6. Only one of the 


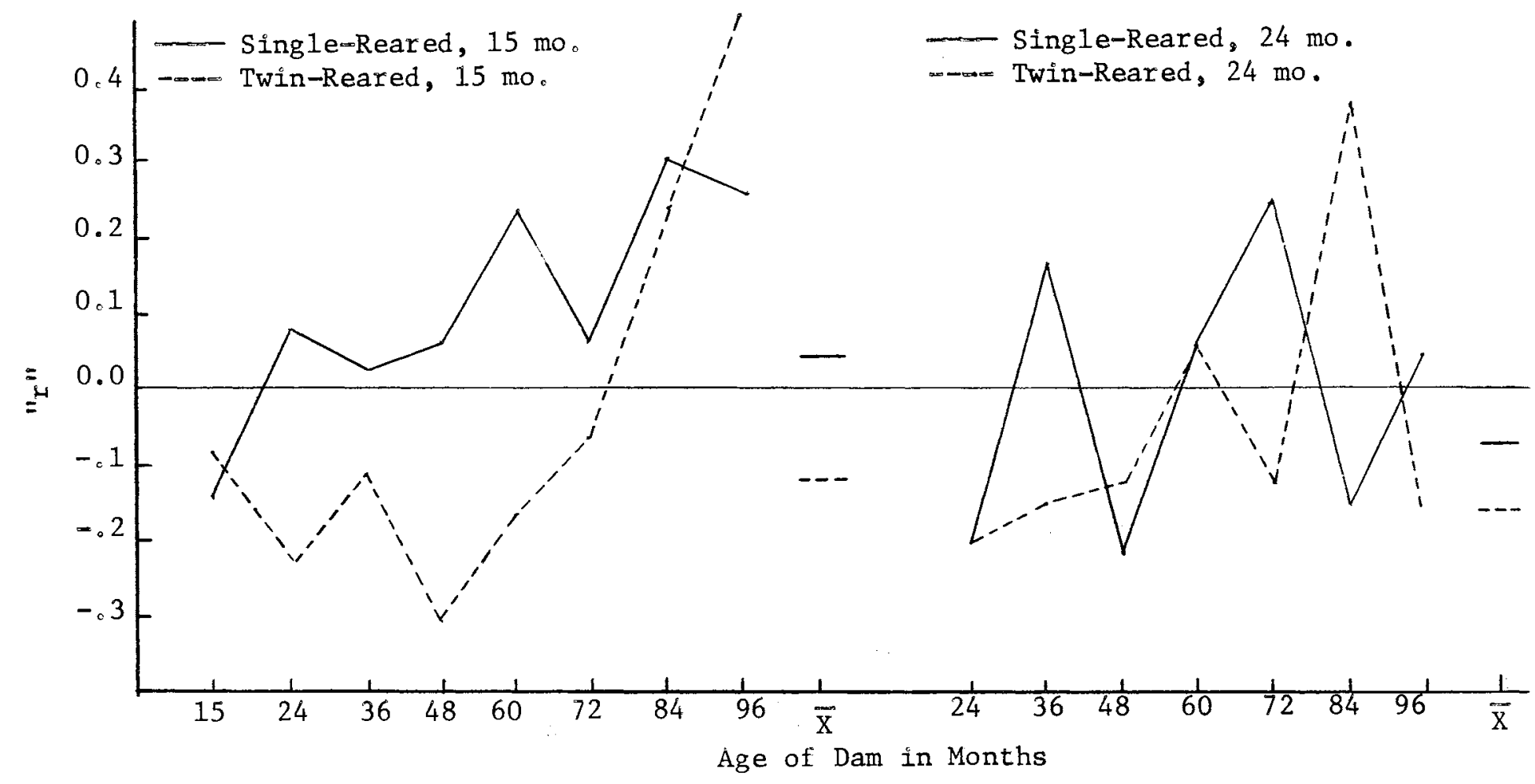

Figure 5. Simple Phenotypic Correlations (r) Between Ewe Gain From Birth to 70 Days and the Gains From Birth to 70 Days of Her Lambs Presented by Age of Dam 


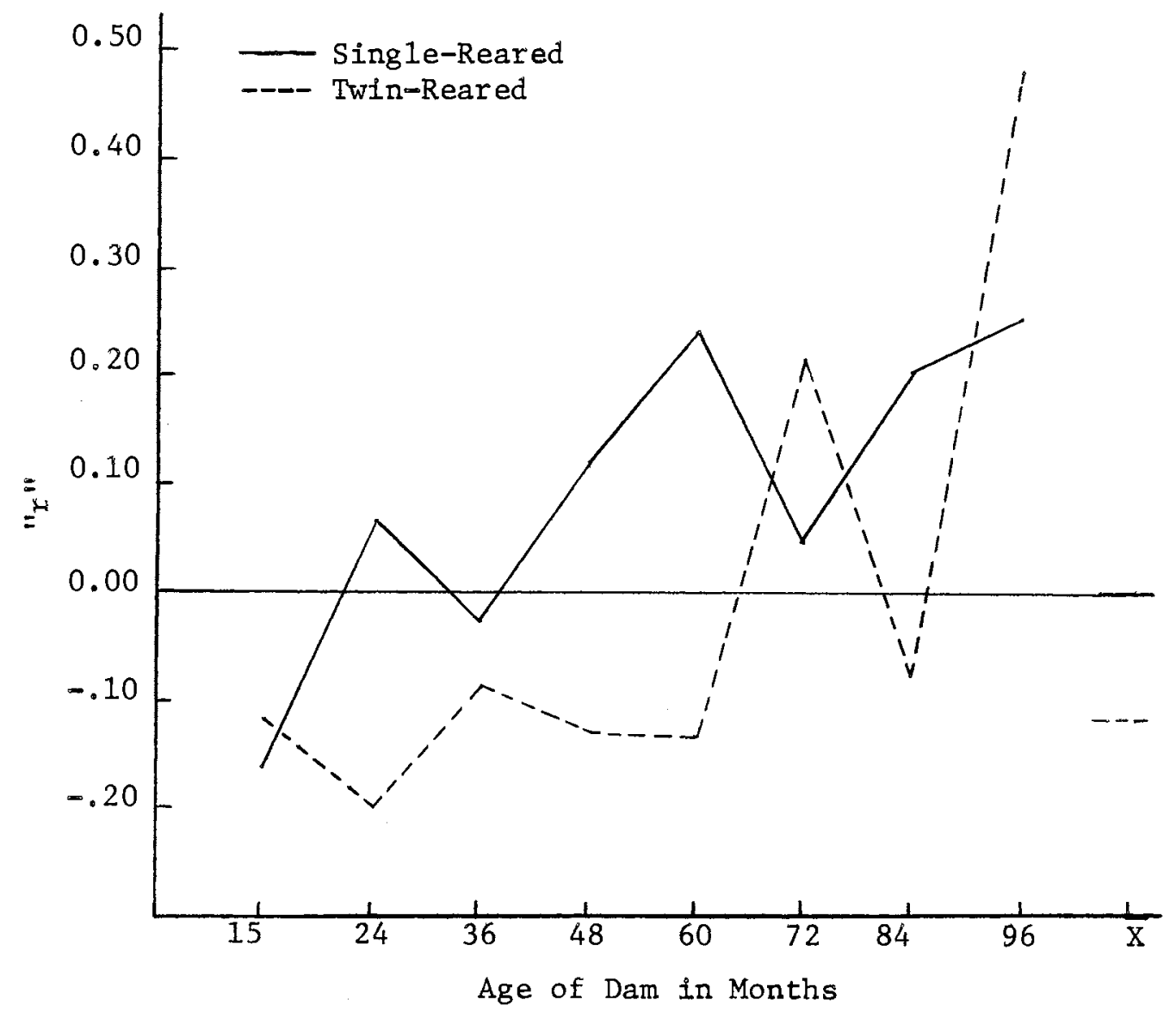

Figure 6. Simple Phenotypic Correlations (r) Between Dam Gain From Birth to 70 Days and the Gain of Her Lambs From Birth to 70 Days With the Data Pooled Over Age of Dam at First Lambing and Presented by Age of Dam 
coefficients (twin-reared dams 96 months old) is significantly $(P<.05)$ different from zero. Also within each age of dam, none of the correlation coefficients for the single and twin-reared dams are significantly $(P<.05)$ different from each other. Consequently the data were further pooled over ewe type of rearing.

The correlation coefficients further pooled over ewe type of rearing are presented in Table IX and are further illustrated in Figure 7. Some fairly obvious trends are evident when the plotted correlation values in Figure 7 are evaluated. When the ewes were quite young (15, 24, 36 and 48 months) the relationships between the ewes' growth rates and of their lambs are zero (48 months) or only slightly negative (15, 24 and 36 months). The phenotypic relationships between the ewes and their lambs are very slightly positive after the ewes reach 60 months of age. As age of dam increases from 15 up to 96 months, the correlation coefficients increase in a positive manner at a relative constant rate from -.19 (15 month old dams) up to 0.27 (96 month old dams). However, only the coefficients relative to dams 15 and 96 months old are significantly $(P<.05)$ different from zero. Although the correlation coefficients for the remaining ages of dams are not significantly $(P<.05)$ different from zero, the steadily increasing (from -.19 to 0.27 ) coefficient values suggest a "very" small negative relationshlp between rate of gain of the ewes from birth to 70 days and rate of gain of their lambs from birth to 70 days of age while the dams were young (48 months and younger). However, this possible small negative relationship is not suggested for dams 60 months or older. The zero or negative correlation coefficlents when the dams were young tend to be in general agreement with the values reported by Butcher et al. (1964) wherein correlations of -.03 
SIMPLE PHENOTYPIC CORRELATIONS BETWEEN EWE AVERAGE DAILY GAIN FROM BIRTH

TO 70 DAYS AND HER LAMB GAINS FROM BIRTH TO 70 DAYS POOLED OVER AGE OF DAM AT FIRST LAMBING AND OVER DAM TYPE OF REARING

AND PRESENTED BY AGE OF DAM

\begin{tabular}{c|ccccccccc}
\hline & \multicolumn{1}{c}{ Age of Dam in Months } \\
\cline { 2 - 8 } & 15 & 24 & 36 & 48 & 60 & 72 & 84 & $\begin{array}{c}\text { Avg. of } \\
\text { All Lambs }\end{array}$ \\
\hline \multirow{2}{*}{$\mathrm{N}$} & 136 & 186 & 182 & 147 & 103 & 97 & 72 & 59 & 240 \\
$\begin{array}{l}\text { Correlation } \\
\text { Coefficients }\end{array}$ & $-.16 *$ & -.04 & -.08 & 0.0 & 0.06 & 0.07 & 0.16 & $0.27^{*}$ & -.09 \\
\hline
\end{tabular}

* Significantly $(P<.05)$ different from zero. 


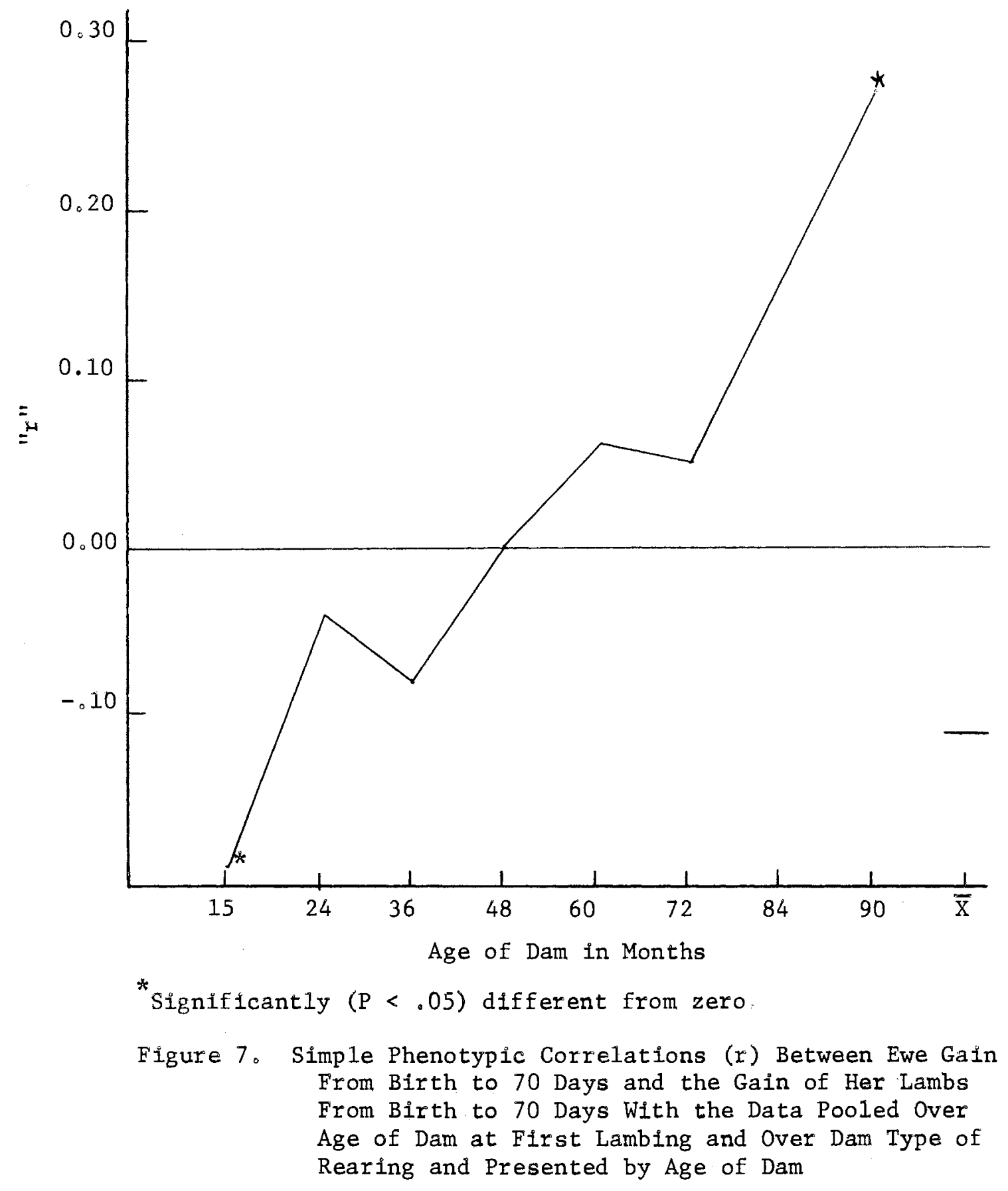


(Hampshire) and 0.04 (Southdown) were reported with no reference to differences related to age of dam.

Koch (1971) suggested that there is evidence for a phenotypic antagonism of genetic and/or environmental nature existing for preweaning beef heifer growth and subsequent milking ability. This possible negative genetic and/or environmental relationship was discussed by Willham (1963) wherein the causal components of dam-progeny covarfance were presented as:

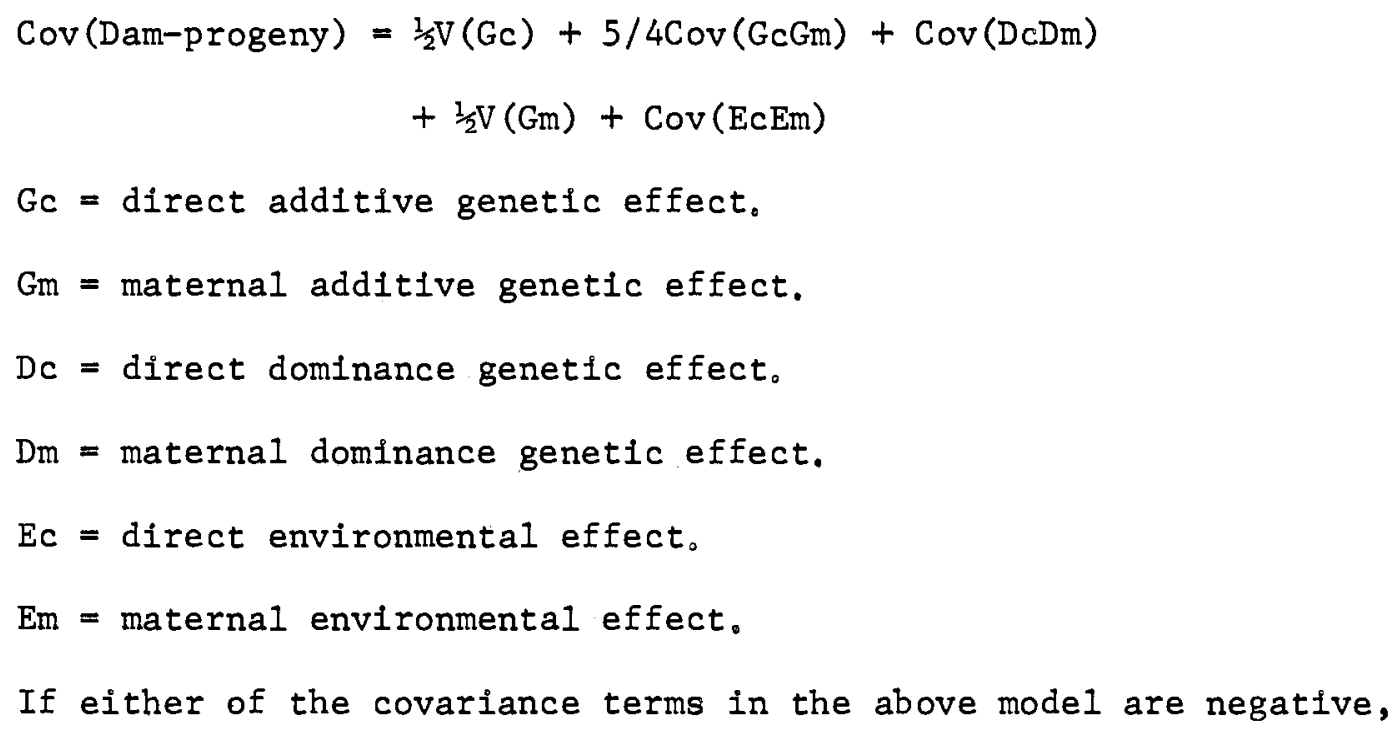

Since in these results the correlation coefficlents are negative when the ewe is young (15 months) and thereafter seem to change toward positive unt1l at about 60 months (age of dam) the coefficient takes on a positive value that further increases with age of dam, then it seems logical that there was a temporary negative relationship expressed between early ewe lamb nutrition and subsequent milking ability when the ewe was young. Koch (1971) also suggested that the genetic correlation 
between lamb growth and maternal ability may be negative. If this is true, the ewe would either give her lambs a plus set of genes for the direct effect and a poor maternal effect or the other way around. However, these results do not indicate this circumstance. These results suggest a negative environmental relationship, and further, this suggested relationship seems to be a temporary characteristic of the ewe.

\section{0-Day Weight}

Correlations between 70-day weight of the ewe and the offspring 70-day weights are very similar to those for ewe and lamb gains from birth to 70 days of age. Similar results would be expected since these two traits are very similar with birth weight the only difference. Thus discussion of 70-day welghts will be limited. The correlation coefficients for the four groups of ewes are presented in Table XV of the Appendix. As was true for gains from birth to 70 days of age, none of the correlation coefficients for any of the groups of ewes for any age of dam are significantly $(P<.05)$ different from zero. Also, differences in correlation coefficients associated with age of dam at first lambing were not significant $(P<.05)$, thus the data were further pooled over age of dam at first lambing. These pooled correlation coefficients are presented in Table XVII of the Appendix. Similar to the rate of gain from birth to 70 days of age, only one of the 18 correlations is significantly $(P<.05)$ different from zero and differences, within age of dam, associated with ewe type of rearing were not significant. However, since only 18 ewe and lamb records are involved in this estimate, the data were further pooled over dam type of rearing. 
These pooled correlations are presented in Table $\mathrm{X}$ and further illustrated in Figure 8 . These results further tend to suggest only a very small negative relationship between early ewe lamb nutrition level and subsequent milking ability when the ewes were $15,24,36$ and 48 months old. Thereafter, a negative relationship is not suggested.

Dam Gain From Birth to 70 Days and Offspring Gain From 70 Days (Weaning) to Market

Since the offspring of the single and twin-reared ewes were weaned at approximately 70 days of age, the relationship between ewe preweaning and lamb post-weaning gain are not of primary interest to this study. However, the correlation coefficlents for each of the four groups of ewes (by age of dam) are presented in Table XVI of the Appendix and are further 1llustrated in Figure 13 of the Appendix. The correlation coefficients for the single and twin-reared ewes (pooled over age of ewe at first lambing) are presented in Table XVII and illustrated in Figure 14 of the Appendix. The correlation coefficlents after further pooling over ewe type of rearing are presented in Table XVIII and Figure 15 of the Appendix. Very briefly summarized, results suggest that the relationship between dam gain from birth to 70 days of age and the gain of their lambs from 70 days to market, at each age of dam, are very near zero. The plotted values in Figure 15 1llustrate that only the relationship $(r=0.32)$ when the dams were 84 months old was significantly $(P<.05)$ different from zero. The estimated relationships at the other ages of dams ranged from -.13 to 0.08 , with none significantly $(P<.05)$ different from zero. In brief summary, results of the phenotypic relationships between the gain of the ewes and the gain of their lambs suggest only a very 
TABLE X

SIMPLE PHENOTYPIC CORRELATIONS BETWEEN EWE 70-DAY WEIGHT AND HER LAMB

70-DAY WEIGHTS PRESENTED FOR EACH AGE OF DAM WITH THE DATA

POOLED OVER AGE OF DAM AT FIRST LAMBING

AND OVER DAM TYPE OF REARING

\begin{tabular}{c|rrrrrrrrr}
\hline & \multicolumn{10}{c}{ Age of Dam in Months } \\
\cline { 2 - 9 } & 15 & 24 & 36 & 48 & 60 & 72 & 84 & $\begin{array}{c}\text { Avg. of } \\
\text { Al1 Lambs }\end{array}$ \\
\hline \multirow{2}{*}{$\mathrm{N}$} & 136 & 186 & 182 & 147 & 103 & 97 & 72 & 59 & 240 \\
$\begin{array}{l}\text { Correlation } \\
\text { Coefficients }\end{array}$ & -.10 & -.01 & -.04 & 0.00 & 0.05 & 0.06 & 0.16 & $0.28^{*}$ & -.06 \\
\hline
\end{tabular}

${ }^{*}$ Significantly $(P<.05)$ different from zero. 


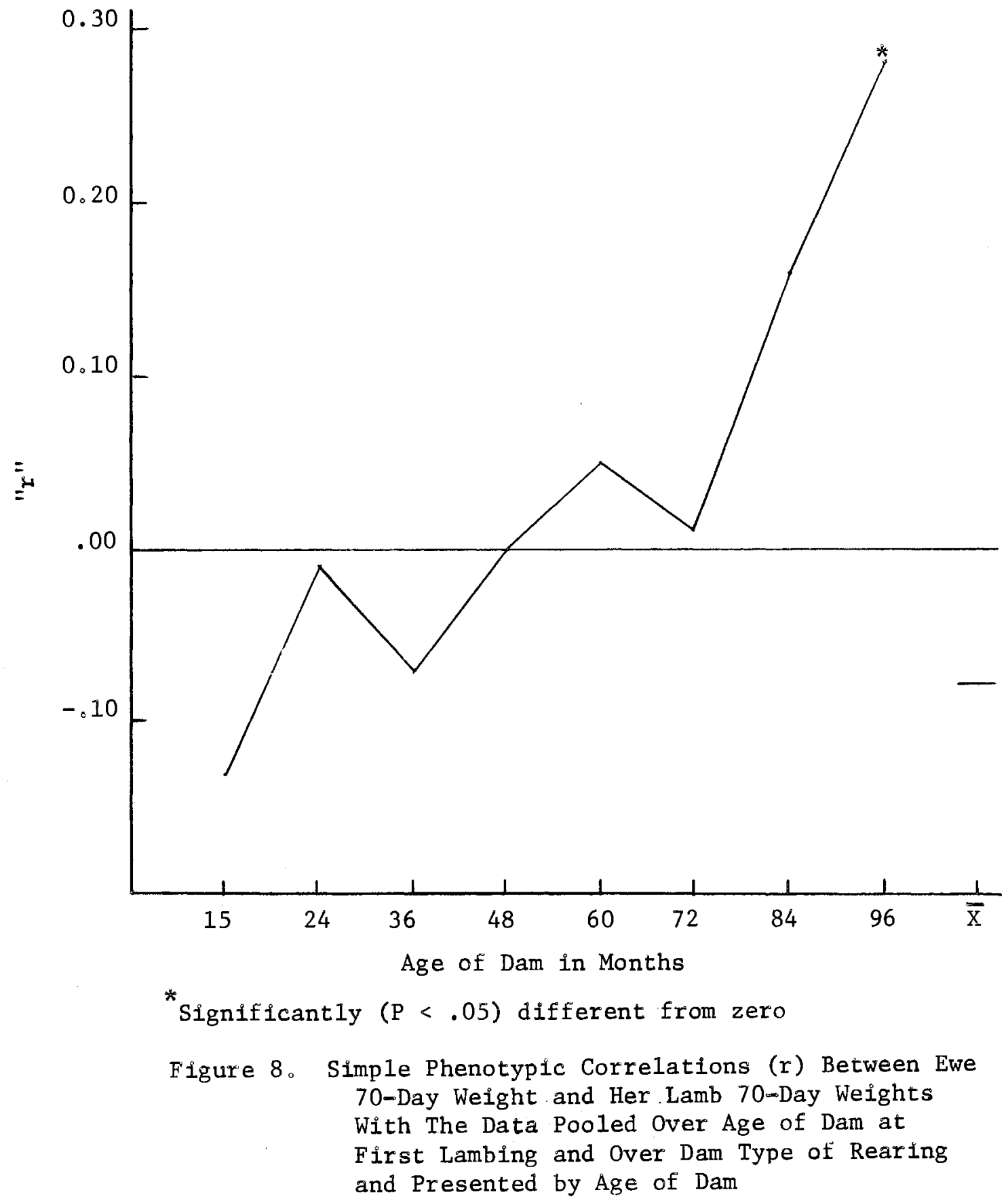


small negative relationship between the preweaning (birth to 70 days) nutrition levels of ewe lambs and their subsequent milking abilities as estimated by the gain of their lambs when the ewes are relatively young. When the dams were $15,24,36$ and 48 months old, the phenotypic relationships, between the gain of the dams from birth to 70 days of age and the gain of their lambs from birth to 70 days of age, were either negative in sign or zero. However, after the ewes reach about 60 months of age, the positive very small correlation coefficients between ewe gain from birth to 70 days and offspring gain from birth to 70 days suggests that this possible negative relationship is not a permanent characteristic over the ewes' entire reproductive life.

However, since phenotypic relationships involve confounding of direct additive genetic and direct maternal genetic as well as several other causal components, the relationship between ewe lamb nutrition (preweaning) and subsequent milk producing ability can not be evaluated completely free of genetic effects. Thus, a second type of analysis will be utilized wherein this relationship can be evaluated relatively free of direct additive genetic effect.

Birth Weights and Preweaning Growth Rates of the Dams in This Study

As indicated earlier, the dams used in this study were normally the earliest ewe lambs (within each dam type of rearing) that reached market weight each year. This would suggest that differences in additive genetic gaining abilities of the single and twin-reared ewes would not be great. Also, if it is assumed that the offspring of these dams received a random sample of the dams genes, then comparisons of the birth weights 
and growth performances of the lambs born to the single and twin-reared ewes would seem to be a method of evaluating the assoclation of early ewe lamb nutrition and subsequent milking ab1lity. The two types of dams had different birth welghts and they exhlbited greatly different growth rates from birth to weaning at 70 days of age. Any harmful effects upon subsequent milking abllities assoclated with these different growth rates should be detectable in the relative growth performances of their progeny. The performances of the dams used in this study are presented in Table XI.

TABLE XI

BIRTH WEIGHTS AND GAINS TO 70 DAYS OF AGE OF THE 240 DAMS (LEAST SQUARES MEANS)

\begin{tabular}{ccc}
\hline & \multicolumn{3}{c}{ Dam Type of Rearing } \\
\cline { 2 - 3 } & Single & Twin \\
\hline B1rth weight & $9.26^{\mathrm{a}}$ & $8.19^{\mathrm{b}}$ \\
Avg. Da. Gain to 70 Days & $0.68^{\mathrm{a}}$ & $0.55_{\mathrm{b}}^{\mathrm{b}}$ \\
70-Day weight & $57.21^{\mathrm{a}}$ & $47.08^{\mathrm{b}}$ \\
\hline $\mathrm{a}, \mathrm{b}$ Significantly different $(\mathrm{P}<.01)$ from each other
\end{tabular}

It is evident that single-reared females were heavier ( 1.07 pounds) at birth, galned faster ( 0.13 pounds per day) from birth to 70 days of age and were much heavier ( 10.13 pounds) at 70 days of age. A more complete description of the ewes is presented in Table XIX of the Appendix based on year of birth of the ewes.

Stuedemann (1967), using beef calves, reported that faster gaining calves from birth to weaning at elght months were normally fatter than slower galning calves. Though no slaughter data were avallable in this study, this would suggest that the single-reared ewes should have been 
fatter at 70 days of age than the twin-reared ewes.

Birth Weights and Preweaning Performance of Lambs

Born to the Single vs. Twin-Reared Ewes

If there truly is a negative relationship between ewe lamb preweaning level of nutrition and subsequent milking ability, the lambs born to the single-reared dams should gain slower from birth to 70 days and should be lighter at 70 days of age than lambs out of the twin-reared ewes.

Birth Weight

Though birth weight as such is not a primary trait of interest in this study, it must be carefully considered since there is a definite relationship between weight at birth and performance to 70 days of age.

The analysis of variance relative to the average birth weights of a11 lambs born to the four groups of ewes is presented in Table XX of the Appendix while the partial regression coefficients for ewe type of rearing and age of ewe at first lambing are presented in Table XXI of the Appendix. Based on the analysis of variance (pooled over all ages of dams), dam type of rearing did not greatly influence $(F=0.02)$ the birth weights of the lambs in this study. This result is in general agreement with those reported by Dun and Grewal (1963) wherein lambs born to twin-reared dams were not greatly different in birth weights from lambs born to single-reared dams.

However, age of dam at first lambing in this study did significantly $(P<.01)$ influence the birth weights of the lambs born to ewes that lambed first at 15 months being 0.22 pounds lighter at birth than lambs born to ewes that lambed first at 24 months of age. Though the 
difference is small it is reasonable that differences in lamb birth weights associated with age of dam at first lambing would exist when the ewes were immature.

The mean lamb birth weights (within ewe type of rearing within age of ewe at first lambing) by age of dam are presented in Table XXVIII of the Appendix. These means are illustrated in Figure 9. The plotted means in Figure 9 suggest that within ewe type of rearing, the association of lamb birth weight and age of dam at first lambing was consistent only until the dams reached 36 to 48 months of age. The lambs born to the ewes that lambed first at 15 months were consistently though not significantly $(P<.05)$ smaller $(0.25$ to 0.05$)$ when the dams were 15 to 48 months of age and thereafter, differences associated with age of dam at first lambing became inconsistent with the only significant $(P<.05)$ differences occurring when the dams were 96 months old. Further, the association between lamb birth weight and age of dam at first lambing appears about equally important for lambs out of single and twin-reared ewes. With these similarities in mind, the data were pooled over age of dam at first lambing on a within age of dam basis.

The mean birth weights of lambs born to single and twin-reared ewes, by age of dam, are presented in Table XXIX of the Appendix and are further illustrated in Figure 10, When the ewes were 15 and 24 months old, lambs out of the twin-reared ewes were 0.14 and 0.09 heavier at birth nonsignificant $(P>.05)$ than lambs out of single-reared ewes. When the ewes were 36 months old, birth weights were essentially equal ( 0.02 pounds difference) for lambs born to the single and twin-reared ewes. When dams were 48 through 96 months of age, consistency was not evident in the birth weights of lambs out of the two groups of dams At 


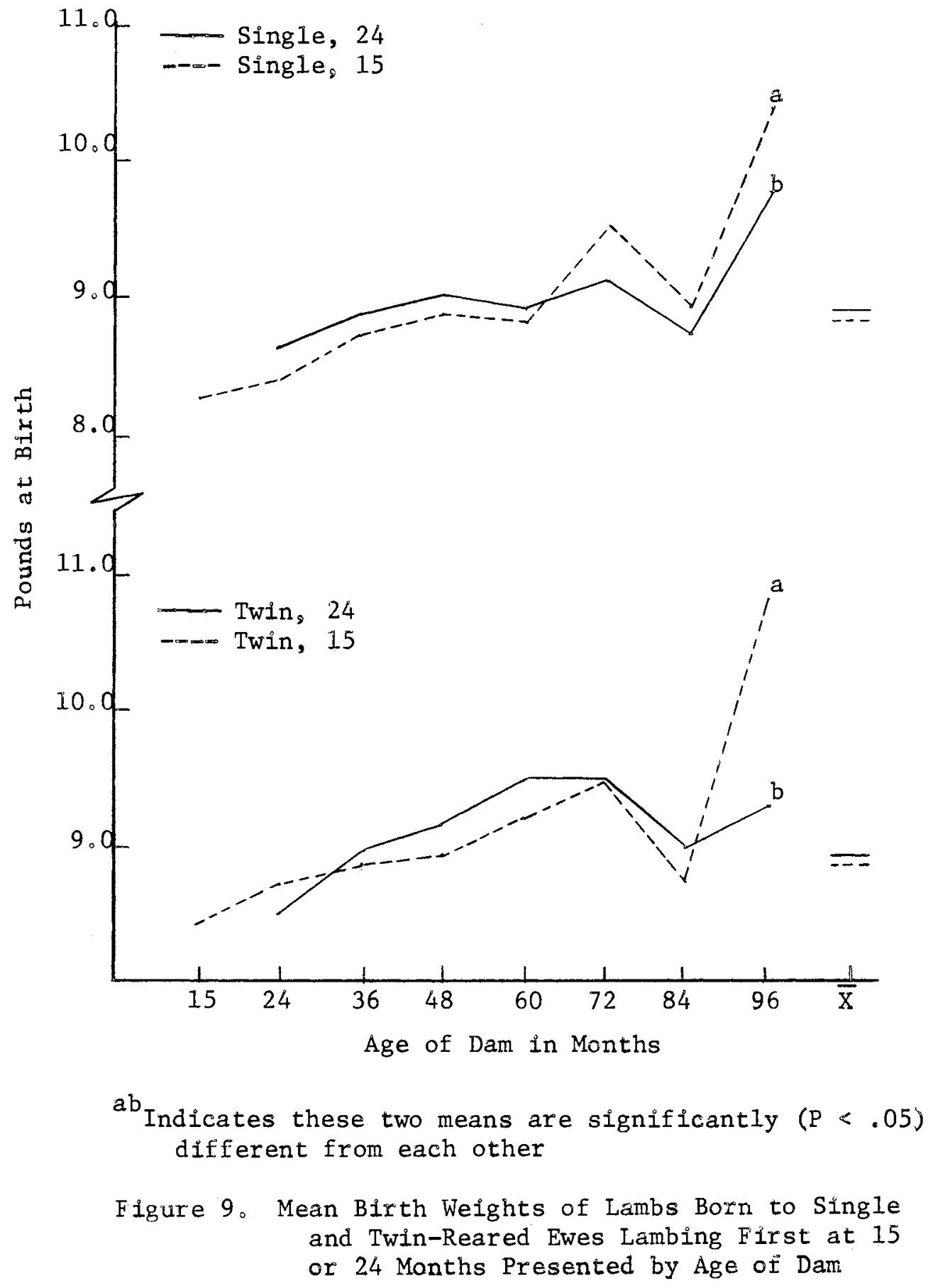




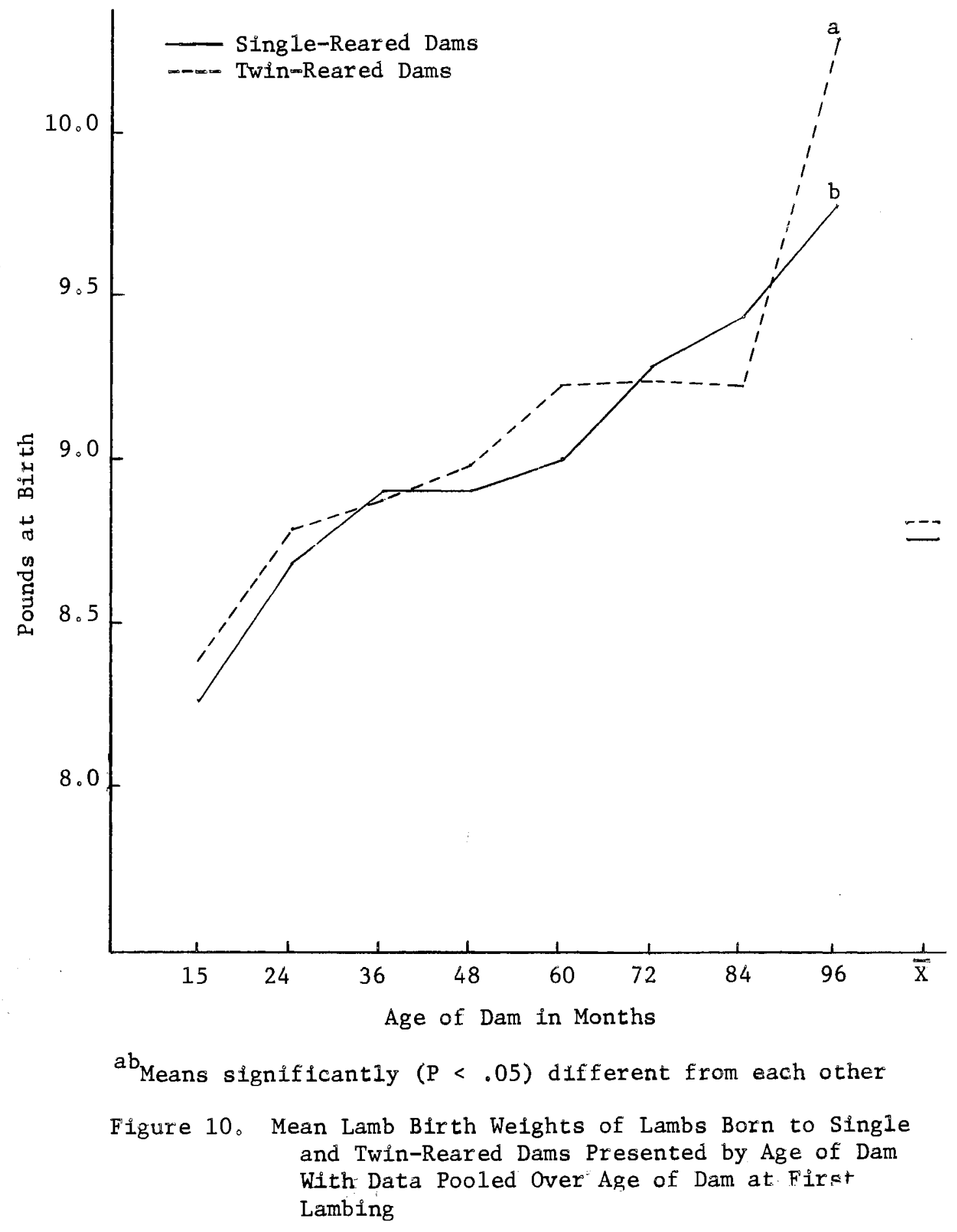


48 and 60 months (age of dam), lambs out of the twin-reared ewes were 0.09 and 0.14 pounds heavier nonsignificant $(P>.05)$ at birth while at 72 months (age of dam birth welghts of lambs out of both groups of ewes were essentially $(0.05)$ pounds difference) the same. When the dams were 84 months old, the lambs out of the single-reared ewes were 0.22 pounds heavier nonsignificant $(P>.05)$ while when the ewes were 96 months old, the lambs out of twin-reared were 1.00 pounds heavier $(P<.05)$ at birth than lambs born to the single-reared ewes. Thus, differences in mean birth weights of lambs born to the twin and single-reared ewes are quite small up to when the dams were 60 months old.

\section{Lamb 70-Day Weights}

In trying to estimate the relationship between preweaning ewe lamb nutrition and offspring growth, the primary trait of interest is the 70-day weights of the lambs born to the single and twin-reared dams. The relatively small differences in birth weights of lambs born to the single and twin-reared ewes are of primary importance since each one pound difference in lamb birth weight may be expected to be assoclated with about three pounds difference in lamb 70-day weight. Based on these results, differences in 70-day weights of the lambs in this study assoclated with differences in birth weights would be expected to be quite small. Lambs born to twin-reared ewes would be expected to weigh $0.42,0.27,0.42$ and 3.0 pounds heavier at 70 days of age when the dams are 15, 24, 48, 60 and 96 months old. Lambs out of single-reared ewes would be expected to weigh $0.06,0.15$ and 0.66 pounds heavier at 36 , 72 and 84 months (age of dam)。

The analyses of variance (over all ages of dams) for lamb 70-day 
weight is presented in Table XXIV of the Appendix, and the partial regression coefficients (for ewe type of rearing and age of ewe at first lambing) are presented in Table XXV of the Appendix。 Relative to the importance of ewe type of rearing and age of ewe at first lambing (over a11 ages of dams), results indicate that over the entire lives of the ewes neither of these variables greatly influenced lamb 70-day weight。 Lambs out of single-reared dams were 0.09 pounds lighter while lambs out of dams that lambed first at 15 months were 0.15 pounds 1 ighter at 70 days of age than lambs out of twin-reared dams or dams that lambed first at 24 months of age, respectively. However, trends are evident when the 70-day weights are evaluated relative to the different ages of dams.

Mean lamb 70-day weights (by age of dam) are presented in Table XXVIII of the Appendix for lambs out of the four groups of ewes and are illustrated in Figure 11. Since significant differences (over all ages of dams) associated with age of dam at first lambing were not apparent, the data were further pooled over age of dam at first lambing. These mean lamb 70-day weights pooled over age of dam at first lambing are presented (by age of dam) in Table XXIX of the Appendix for the lambs out of the single and twin-reared dams. The mean 70-day weights of the lambs born to the single and twin-reared dams are illustrated in Figure 12. Evaluation of the mean 70-day weights illustrated in Figure 12 suggest that when the dams were young (15, 24 and 36 months), lambs out of the twin-reared ewes were consistently heavier at 70 days than lambs born to the single-reared dams. After the dams reached 48 months of age consistent differences in 70-day weights of lambs out of the two groups of ewes are not apparent. Lambs out of 15, 24 and 36 months old dams were $2.3,1.4$ and 0.7 pounds heavier than lambs out of single-reared dams: 


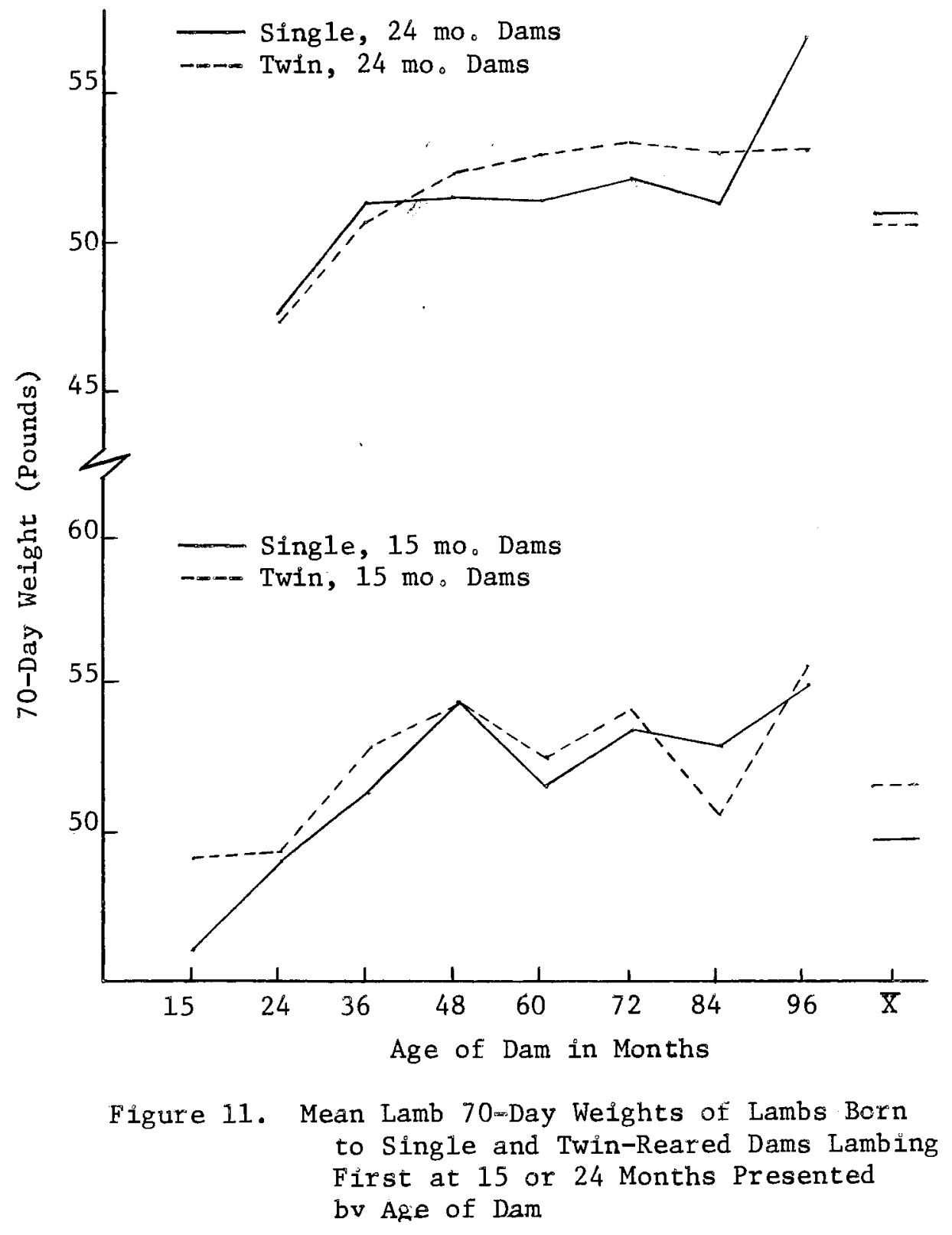




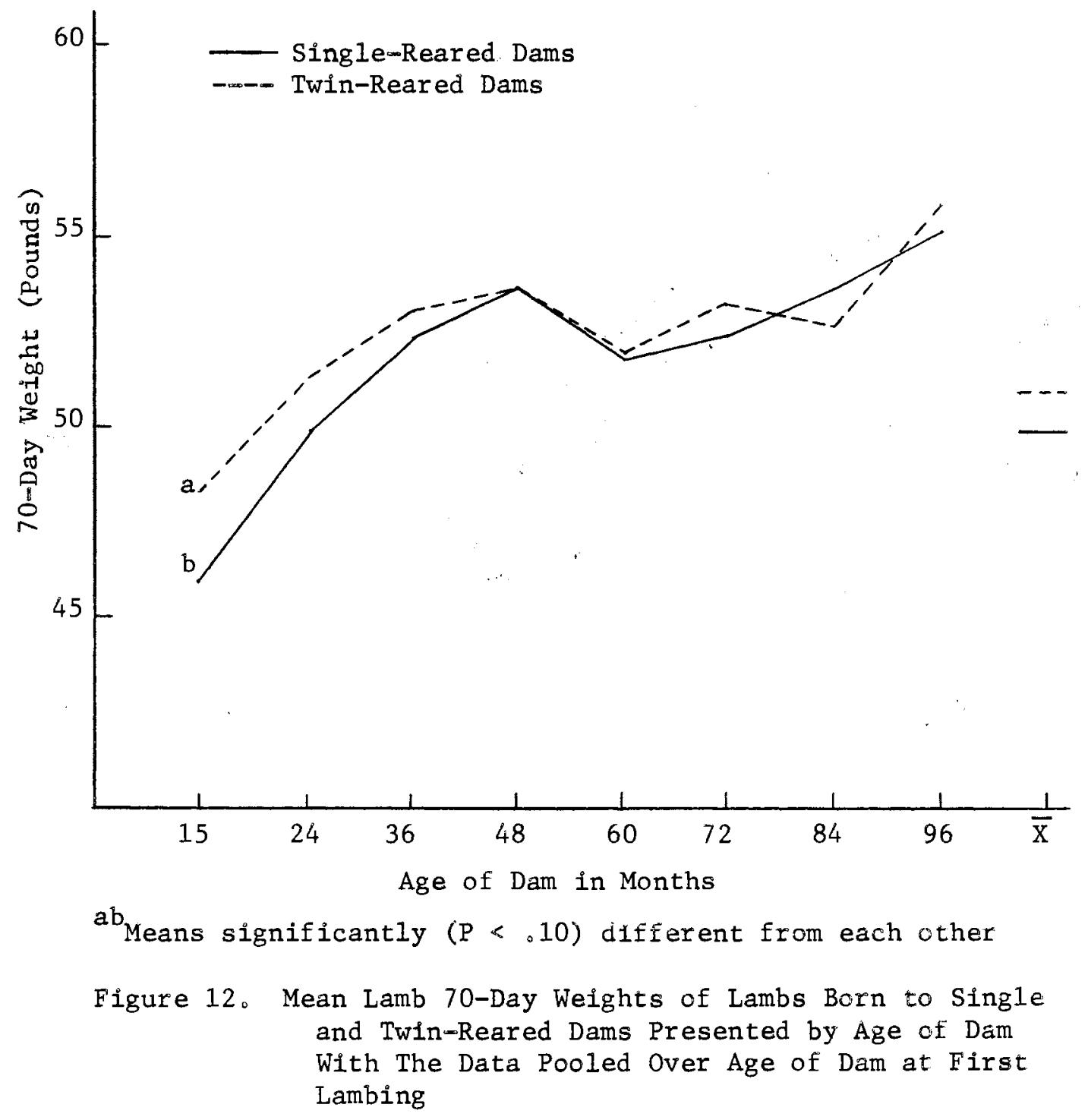


The difference ( 2.3 pounds) when the dams were 15 months old approached significance $(P<.10)$. These differences in 70-day weights when the dams were 15 through 36 months old are considerably greater than should be expected based strictly on differences in blrth weights. After the dams reached 48 months of age, consistent and significant $(P<.05)$ differences in 70-day weights of lambs out of the single and twin-reared were not evident. When the dams were 48 and 60 months old, the offspring 70-day weights were essentlally equal (53.7 vs. $53.7 ; 51.8$ vs. 51.9 ). When the dams were over 60 months old, the 70-day weights were inconsistently in favor of neither the lambs born to the single or twinreared dams. Even though lambs out of the twin-reared dams were significantly $(P<.10)$ heavier at 70 days of age only when the dams were 15 months old, the consistency of their heavier 70-day weights when the ewes were young further suggests that there may be a small, temporary negative relationship between the nutrition level from birth to 70 days of ewe lambs and their subsequent milking abilities as estimated by offspring 70-day weights. Also, these results suggest that this relationship is environmental rather than genetic in nature。

Dun and Grewal (1963) reported that lambs born to twin-reared dams gained at essentially equal rates from birth to 120 days of age and were very similar in weights at 120 days as lambs out of single-reared ewes. However, partioning the gains and weights relative to different ages of dams was not done in that study.

\section{Lamb Gain From Birth to 70 Days of Age}

Results relative to the mean gains from birth to 70 days of age of the lambs out of the single and twin-reared dams lambing first at 15 or 
24 months of age are very similar to the results for 70-day weights. The analyses of variance for lamb gain from birth to 70 days of age (over al1 ages of dams is presented in Table XXII while partial regression coefficients (for dam type of rearing and age of dam at first lambing) are presented in Table XXIII of the Appendix. As was true for 70-day weights, differences associated with age of dam at first lambing or dam type of rearing were nonsignificant $(P<.05)$ over all ages of dams. The mean average daily gains of the lambs out of the four groups of dams are illustrated in Figure 16 of the Appendix. The mean average daily gains after pooling over age of dam at first lambing on a within age of dam basis are illustrated in Figure 17 and are presented in Table XXIX of the Appendix。 The same trends are suggested for lamb gain from birth to 70 days of age as were true for $1 \mathrm{amb} 70$-day weight. Thus, these results further suggest a very small negative relationship between preweaning ewe lamb nutrition and subsequent milking ability as estimated by offspring growth from birth to 70 days of age when the dams were quite young.

\section{Lamb Gains From 70 Days of Age to Market}

The trait lamb gain from 70 days of age to market at about 95 pounds was not of primary importance in this study because the lambs were weaned at 70 days of age. However, the analyses of variance and partial regression coefficients (over all ages of dams) are presented in Tables XXVI and XXVII of the Appendix. Both ewe type of rearing and age of ewe at first lambing were nonsignificantly associated with lamb post-weaning gain when calculated over all ages of dams. The mean lamb gains from 70 days to market for lambs born to the four groups of ewes are presented in Table XXVIII of the Appendix and are further illustrated in Figure 18 
of the Appendix. The means (pooled over age of dam at first lambing) for lambs out of the single and twin-reared ewes are presented in Table XXIX of the Appendix and are further illustrated in Figure 19 of the Appendix. When the dams were 15,84 and 96 months old, the lambs out of the twinreared dams gained $0.02,0.03(P<.05)$ and 0.02 pounds per day faster than lambs out of the single-reared dams. However, when the dams were 24, 48, 60 and 72 months old, lambs out of the single-reared dams gained $0.01,0.03(\mathrm{P}<.05), 0.01$ and 0.02 pounds per day faster than lambs out of the twin=reared dams.

\section{Relationships Among Maternal Half-Sibs}

Relationships among the maternal half-sibs born to the single and twin-reared dams were considered in this study since the data were available. However, since the phenotypic relationships between the growth of ewes and of their lambs were in general all very low for all traits considered, this suggests that in a selection program aimed at increasing lamb preweaning gains the dams own preweaning performance would be of little value relative to estimating the growth performance of her lambs. Since the data were avallable, repeatabilities relative to birth weight, gain to 70 days, 70-day weight, and post-weaning gain were estimated。

Repeatability estimates were accomplished by means of simple phenotypic correlations among maternal half-sibs born to the single and twin-reared ewes. Repeatabilities were further estimated by simple linear regression of certain later records on earlier records。 Correlation coefficients were calculated between the birth weight of the first lamb born to a ewe and the average birth weight of the $3 \mathrm{rd}$ through 
the 8 th lambs born to a ewe (in Table XII, this estimate of repeatability is designated as "Records 3-8; Record 1"), between the birth weight of the second lamb born to a ewe and the average birth weight of the third through the 8 th lambs born to a ewe (in Table XII, designated as "Records 3-8; Record 2") and between the average birth weight of the first and second lambs born to a ewe and the average birth weight of the 3rd through the 8th lambs born to a ewe (in Table XII, designated as "Records 3-8; Records 12")。 The same basic correlation coefficients were calculated for the traits rate of gain from birth to 70 days, 70-day weight, and rate of gain from 70 days to market. Regression coefficients were also calculated by regressing the later lamb records (for each trait) on the earlier lamb records.

The estimates of correlation and regression coefficients could be used as unbiased estimates of repeatability (Cunningham and Henderson, 1961) for the traits of interest. Further, Cunrow (1961) indicated that if culling on earlier records were not practiced, correlation coefficient estimates of repeatabilities should be as meaningful as regression coefficient estimates.

The estimates of repeatabilities for lambs out of the four groups of dams are presented in Table XXX of the Appendix. Gross differences in correlation coefficient values seem not to be associated with age of dam at first lambing. Within each ewe type of rearing, within each trait, within each method of estimating repeatability, differences in the values of the correlations for the dams that lambed first at 15 and 24 months of age are significant $(P<.05)$ in only one instance. The remaining comparisons (23) between the lambs born to ewes that lambed first at 15 vs. 24 months of age for both single and twin-reared dams for each trait are 
not significantly $(P<.05)$ different. Consequently, the data were pooled over age of ewe at first lambing.

The repeatability estimates after pooling over age of dam at first lambing are presented in TableXII。 Referring to the correlation coefficients in Table XII, much similarity is observed for lambs born to the single and twin-reared dams. Upon evaluation, none of the corresponding correlation coeficients (lambs out of single.vs. lambs out of twin-reared ewes within each trait within each method of estimation) for lambs born to the two types of dams were detected significantly $(P<.05)$ different for each other. Thus, the data were further pooled over ewe type of rearing.

The pooled estimates of repeatabillty are presented in Table XIII. Relative to the trait birth welght, even though selection is seldom done on this trait alone, it may be of value to estimate the repeatability in light of the association between birth weight and later lamb gains. The repeatability estimate $(0.23)$ based on the correlation between the first lamb born to the ewes and the average birth weight of the 3rd through the 8th lambs (first line in the body of Table XIII) can be considered in the moderate range. Utilizing the second lamb born to the ewes, (second Iine in the body of Table XIII), the estimated repeatability $(0.31)$ is oniy slightly higher than that based on the first lamb born to the ewes. However, when the average of the first and second lambs born to the ewes (third line in the body of Table XIII) was used to estimate the repeatability of birth welght, the correlation coefficient of 0.35 is increased over that when only the first lamb (0.23) or the second lamb $(0.31)$ was used alone, All three estimates of the repeatability of lamb birth were significantly $(P<.05)$ different from zero. These estimates of repeat- 
TABLE XII

SIMPLE PHENOTYPIC CORRELATIONS ( $r$ ) BETWEEN VARIOUS LAMB RECORDS FOR SEVERAL TRAITS AND SIMPLE LINEAR REGRESSIONS (b) OF CERTAIN LATER LAMB RECORDS ON EARLIER RECORDS FOR LAMBS BORN TO THE SINGLE AND TWIN-REARED DAMS (POOLED OVER AGE OF DAM AT FIRST LAMBING)

\begin{tabular}{|c|c|c|c|c|c|c|c|c|}
\hline \multirow[b]{2}{*}{ Lamb Traits } & \multicolumn{4}{|c|}{ Single-Reared Dams } & \multicolumn{4}{|c|}{ Twin-Reared Dams } \\
\hline & $\mathrm{b}$ & $\mathrm{s}_{\mathrm{b}}^{\mathrm{e}}$ & $r$ & $\mathrm{~N}^{\mathrm{f}}$ & $\mathrm{b}$ & $s_{b}^{e}$ & $r$ & $\mathrm{~N}^{f}$ \\
\hline $\begin{array}{l}\text { Birth Weight } \\
\quad \text { Records } 3-8 \text {; Record } 1^{\mathrm{b}} \\
\text { Records } 3-8 ; \text { Record } 2{ }^{\mathrm{c}} \\
\text { Records } 3-8 \text {; Record } 12^{\mathrm{d}}\end{array}$ & $\begin{array}{l}0.15 \\
0.23 \\
0.31\end{array}$ & $\begin{array}{l}0.07 \\
0.06 \\
0.09\end{array}$ & $\begin{array}{l}0.20 \\
0.33 \\
0.34\end{array}$ & $\begin{array}{l}115 \\
113 \\
116\end{array}$ & $\begin{array}{l}0.23 \\
0.26 \\
0.36\end{array}$ & $\begin{array}{l}0.09 \\
0.07 \\
0.09\end{array}$ & $\begin{array}{l}0.29 \\
0.36 \\
0.39\end{array}$ & $\begin{array}{l}79 \\
77 \\
79\end{array}$ \\
\hline $\begin{array}{l}\text { Av. Daily Gain Birth } \\
\text { to } 70 \text { Days } \\
\text { Records } 3-8 ; \text { Record } 1 \\
\text { Records } 3-9 ; \text { Record } 2 \\
\text { Records } 3-8 ; \text { Record } 12\end{array}$ & $\begin{array}{l}0.23 \\
0.28 \\
0.22\end{array}$ & $\begin{array}{l}0.07 \\
0.07 \\
0.07\end{array}$ & $\begin{array}{l}0.26 \\
0.31 \\
0.27\end{array}$ & $\begin{array}{r}93 \\
96 \\
111\end{array}$ & $\begin{array}{l}0.04 \\
0.28 \\
0.19\end{array}$ & $\begin{array}{l}0.07 \\
0.09 \\
0.07\end{array}$ & $\begin{array}{l}0.07 \\
0.33 \\
0.23\end{array}$ & $\begin{array}{l}65 \\
67 \\
75\end{array}$ \\
\hline $\begin{array}{ll}\text { 70-Day Weight } & \\
\text { Records 3-8; Record } 1 \\
\text { Records 3-8; Record } 2 \\
\text { Records 3-8; Record } 12\end{array}$ & $\begin{array}{l}0.20 \\
0.26 \\
0.24\end{array}$ & $\begin{array}{l}0.07 \\
0.07 \\
0.07\end{array}$ & $\begin{array}{l}0.25 \\
0.35 \\
0.32\end{array}$ & $\begin{array}{r}93 \\
96 \\
111\end{array}$ & $\begin{array}{l}0.05 \\
0.34 \\
0.21\end{array}$ & $\begin{array}{l}0.08 \\
0.10 \\
0.09\end{array}$ & $\begin{array}{l}0.09 \\
0.39 \\
0.24\end{array}$ & $\begin{array}{l}65 \\
67 \\
75\end{array}$ \\
\hline $\begin{array}{l}\text { Av. Daily Gain } 70 \text { Days } \\
\text { to Market } \\
\text { Records } 3-8 ; \text { Record } 1 \\
\text { Records } 3-8 ; \text { Record } 2 \\
\text { Records } 3-8 ; \text { Record } 12\end{array}$ & $\begin{array}{l}0.12 \\
0.00 \\
0.09\end{array}$ & $\begin{array}{l}0.05 \\
0.06 \\
0.06\end{array}$ & $\begin{array}{l}0.17 \\
0.00 \\
0.15\end{array}$ & $\begin{array}{r}86 \\
88 \\
106\end{array}$ & $\begin{array}{l}0.10 \\
0.11 \\
0.09\end{array}$ & $\begin{array}{l}0.08 \\
0.10 \\
0.09\end{array}$ & $\begin{array}{l}0.14 \\
0.19 \\
0.16\end{array}$ & $\begin{array}{l}61 \\
63 \\
75\end{array}$ \\
\hline $\begin{array}{l}a_{\text {Records } 3-8=\text { The averag }} \\
\text { born to the ewes } \\
b_{\text {Record } 1=\text { The performan }} \\
{ }^{c_{\text {Record }} 2=\text { The performan }} \\
d_{\text {Record } 12=\text { The average }} \\
\text { the ewes } \\
e_{\text {The standard error of th }} \\
\mathrm{f}_{\text {The number of records co }}\end{array}$ & of & $\begin{array}{l}\text { e } 1 s t \\
\text { nce of }\end{array}$ & $\begin{array}{l}\text { of th } \\
\text { lamb } \\
\text { lamb } \\
\text { the }\end{array}$ & $\begin{array}{l}\text { orn } \\
\text { orn }\end{array}$ & $\begin{array}{l}\text { the } \\
\text { the } \\
\text { 2nd }\end{array}$ & $\begin{array}{l}\text { he the } \\
\text { ewes } \\
\text { ewes } \\
\text { lambs }\end{array}$ & 8 th & abs \\
\hline
\end{tabular}


TABLE XIII

SIMPLE PHENOTYPIC CORRELATIONS ( $r$ ) BETWEEN VARIOUS LAMB RECORDS FOR SEVERAL TRAITS AND SIMPLE IINEAR REGRESSIONS (b) OF CERTAIN LATER LAMB RECORDS ON EARLIER LAMB RECORDS (POOLED OVER AGE OF DAM AT FIRST LAMBING AND OVER DAM TYPE OF REARING)

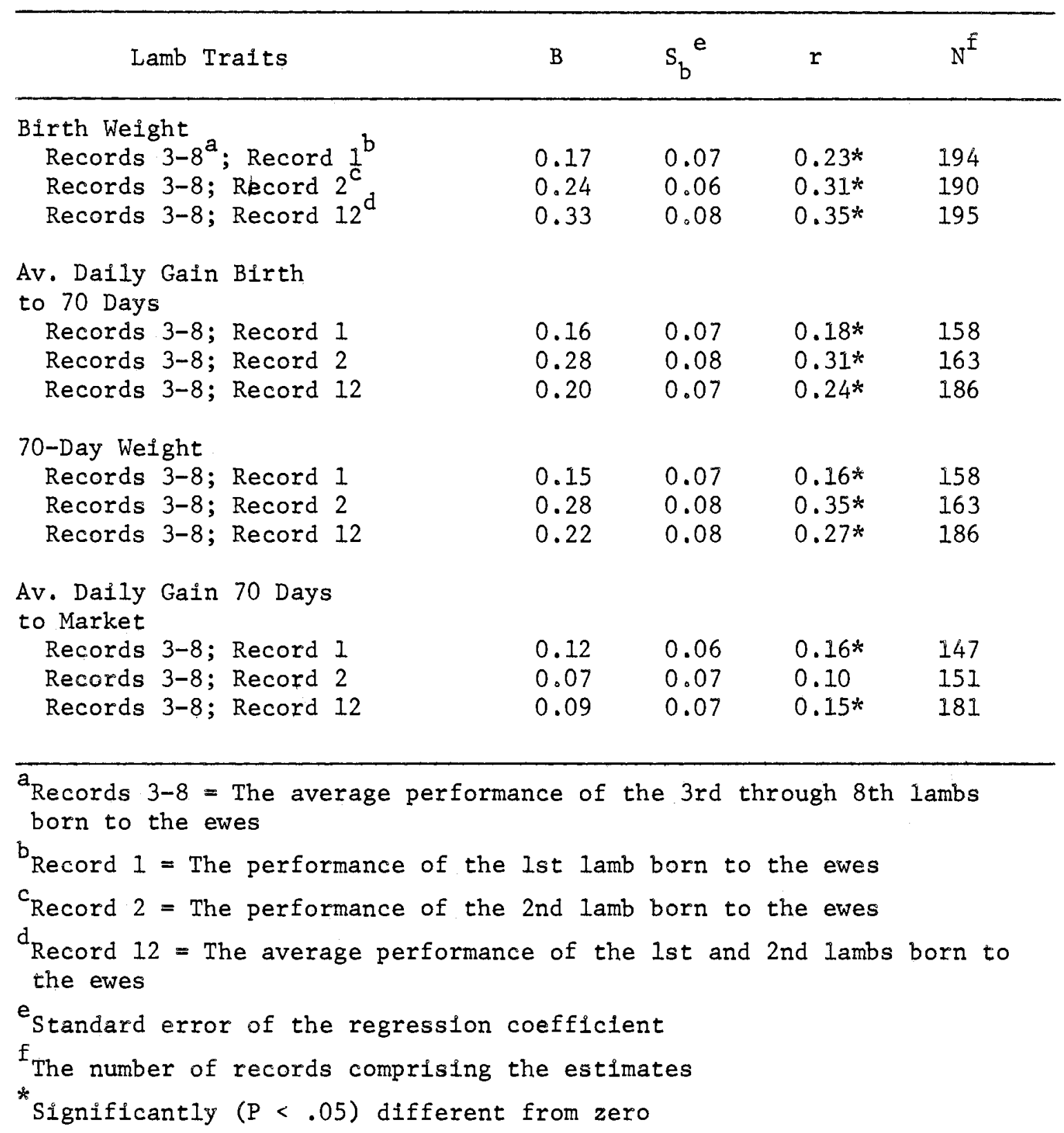


ability of birth weight agree quite well with those reported by Harrington (1963) wherein estimates ranging from about 0.20 to 0.36 were reported for lambs similar in breeding to the lambs in this study. Further, MacNaughton (1957) reported a repeatability estimate of 0.36 for Corriedale and 0.27 for Rambouillet lambs.

Referring to Table XIII, the repeatability estimate of lamb 70-day weight based on the first lamb ( 7 th line of Table XIII) was 0.16 while based on the second lamb born to the ewes (8th line of Table XIII) the estimated repeatability was increased to 0.35 . Thus the repeatability estimate $(0.27)$ based on the average of the first and second lambs born to the ewes ( 9 th line of Table XIII) was intermediate to the estimates based on either of the first two lambs. These results suggest that if selection were to be done solely on 70-day weights, it would be of considerable value to have the second lamb record.

Most of these estimated repeatabilities are somewhat higher than others reported in the literature. Sidwell and Grandstaff (1949) reported an estimated repeatability of 0.22 for weaning weight at 120 days of age for Navajo lambs while MacNaughton (1957) reported an estimate of 0.25 for both Corriedale and Ramboullet lambs. Harrington (1963) reported an estimated repeatability of 0.12 to 0.23 using lambs of similar breeding to those in this study.

The repeatability estimates relative to lamb gain from birth to 70 days of age are also presented in Table XIII, Since these estimates are very similar to those discussed for lamb 70-day weight, results of estimated repeatabllities of lamb gain from birth to 70 days of age will not be discussed. 
Relative to the estimated repeatability of lamb gain from 70 days of age to market, it seems that the first lamb born to the ewes results in a slightly higher repeatability than when later lambs were utilized. Referring again to the estimates presented in Table XIII, the repeatability estimate based on the first $1 \mathrm{amb}$ born to the ewes is somewhat higher (0.16 vs. 0.10$)$ than when based on the second lamb born to the ewes. Also, the repeatability estimate based on the average of the first and second lambs is slightly smaller $(0,15)$ than when based on the first lamb born to the ewes. However, only the repeatabilities estimated using the first lamb or the average of the first and second lambs were significantly $(P<.05)$ different from zero. Harrington (1963) reported repeatability estimates of about 0.14 for post-weaning rate of gain of lambs similar in breeding to those in this study。

In all cases, repeatability estimates based on the regression of later on earlier lamb records were slightly smaller than based on corm relations of earlier and later lamb records. This would seem reasonable since the denominator in the case of correlations utilizes the variance estimates of both the later and earlier records while the regression estimator involves only the use of the variance of the earlier record. The variance of the earlier record would be expected to be larger than the variance of the later records (average of lambs three through eight) since the variance based on an average of several lambs would be expected to be smaller than when based on only one lamb (the first or second). In this respect, repeatabilities based on regression estimates in this study are more comparable with others reported in the literature than those based on the correlation coefficient estimates。 


\section{CHAPTER V}

\section{SUMMARY}

Data available from 129 single and 111 twin-reared Dorset X Western ewes were utilized to estimate the relationship between preweaning ewe lamb nutrition level and subsequent milking ability as estimated by offspring performance from birth to 70 days and offspring 70-day weight. Initial analyses were done within dam type of rearing within age of dam at first lambing. Within these classifications, analyses were done on a within age of dam (15 months, 24, 36, 。。, 96 months) basis。 The single and twin-reared dams produced 984 and 627 lambs that were utilized in this study.

The relationship between preweaning ewe lamb nutrition and subsequent milking ability was evaluated by: (1) determining phenotypic relationships between the dams and their lambs relative to birth weights and subsequent gains and (2) by comparing the birth weights and subsequent gains of the lambs born to the single and twin-reared dams。

Relative to birth weight, the correlation coefficients between ewe birth weight and the birth weights of her various lambs were very small $(-.02$ up to 0.15$)$ for each age of dam (15 months up to 96 months) with none being detected significantly $(P<.05)$ different from zero. Differences in correlation coefficients within each age of dam were not assoclated with ewe type of rearing or age of dam at first lambing。 
Relative to the relationships between ewe gain and the gains from birth to 70 days of age of her various lambs, differences in correlation coefficients for each age of dam were not apparently associated with ewe type of rearing (single vs. twin-reared) or age of dam at first lambing (15 or 24 months)。 The correlation coefficients relative to gain from birth to 70 days (pooled over age of dam at first lambing and over ewe type of rearing) were significantly $(P<.05)$ different from zero only at the ages of dams 15 and 96 months. However, there was an apparent trend for the estimated ewe-offspring relationships to be slightly negative when the dams were 15, 24 and 36 months of age, zero when the dams were 48 months old, and increasingly positive when the dams were 60,72 。 84 and 96 months old. The correlation coefficients were $-.19,-.04,-.08$, $0.00,0.06,0.05,0.16$ and 0.27 when the dams were $15,24,36,48,60$, 72, 84 and 96 months old. This trend of negative relationships when the dams were young, approaching zero at a steady rate and then as the ewes became mature the relationships becoming increasingly larger in a positive manner suggest that there may be a very small negative association between preweaning ewe lamb nutrition level and subsequent milking ability when the ewe is young. This suggested negative relationship appears to gradually disappear as the ewes reach 60 months of age.

Results relative to ewe and lamb 70-day weights were very simflar to those discussed for ewe and lamb gains from birth to 70 days of age. However, since phenotypic relationships between dam and offspring involve confounded direct additive genetic and direct maternal genetic effects, the data were analyzed in a second way to estimate the relation= ship of interest relatively free of the direct additive genetic component. 
The single-reared dams were heavier $(P<.01)$ at birth $(9.26 \mathrm{vs}$. 8.19 pounds), gained faster $(\mathrm{P}<.01)$ from birth to weaning at 70 days of age $(0.68$ vs. 0.55 pounds per day) and were thus heavier $(P<.01)$ at 70 days of age ( 57.2 vs. 47.0 pounds) than the twin-reared dams 。

The birth weights of the lambs born to the single and twin-reared ewes were very similar at all ages of the ewes. At ages of dams 15, 24, $36,48,60$ and 72 months the difference in the birth weights of the lambs out of the single and twin-reared ewes was 0.15 pounds or less. These small differences suggest that differences in the 70-day weights of the lambs born to the single and twin-reared ewes associated with differences In birth weights, should be quite small (less than $\frac{1}{2}$ pound at most ages of dams).

Relative to the mean 70-day weights, lambs out of the twin-reared ewes were consistently heavier at 70 days of age than lambs born to the single-reared dams when the ewes were quite young. When the dams were 15, 24, and 36 months old, the lambs out of the twinmreared ewes were 2.3, $(P<.10), 1.4$ and 0.7 pounds heavier at 70 days than the lambs out of the single-reared ewes. After the dams reached 48 to 60 months of age, differences in the 70-day weights of lambs born to single and twinreared ewes were small and not consistently in favor of lambs out of either type of dam. Results relative to gain from birth to 70 days of age for the lambs out of the single and twin-reared dams were very similar to results relative to 70-day weight. These results further suggest only a very smali negative relationship between preweaning ewe lamb nutrition and subsequent milking ability when the dams were quite young (15 to 36 months)。 
Since the very low phenotypic ewe-offspring relationships suggest very limited usefulness of a ewe's own growth performance as a lamb for estimating the growth performance of her offspring, repeatabilities of lamb birth weight and subsequent lamb performance were calculated。These repeatabilities were estimated by means of simple phenotypic correlation and simple linear regression techniques.

Relative to lamb birth weight, a correlation coefficient of 0.23 suggests that the first lamb born to a ewe would be of considerable value for estimating later progeny (her third through her eighth) birth weights. The repeatability of lamb birth weight based on the second lamb $(0.31)$ or the average of the first and second lambs $(0.35)$ would suggest only limited superiority over the first lamb record for estimating the subsequent lamb birth weights.

Relative to the repeatabilities of lamb gain from birth to 70 days of age and 70-day weight, results were very similar. The estimated repeatability of lamb 70-day weight based on only the first lamb record (0.16) was somewhat lower than when the repeatability was estimated utilizing the second lamb record (0.35) or the average of the first and second lamb records (0.27). This would indicate that if selection is to be based on 70-day weight or gain from birth to 70 days of age, it may be quite useful to obtain the record of the second lamb born to the ewes.

The estimated repeatability of lamb gain from 70 days to market based on the first lamb born $(0.16)$ was only slightly higher than repeatabilities based on the second lamb (0.10) and based on the average of the first and second lambs $(0.15)$ produced by the ewes. This would suggest that one lambing record would be sufficlent criteria for selection of 
replacement ewes if selection were based on lamb gain from weaning at

70 days of age to market at about 95 to 100 pounds. 


\section{LITERATURE CITED}

Barnicoat, C. R., P。F。Murray, E. M. Roberts and G. S. Wilson。 1956。 Milk-secrete studies with New Zealand Romney ewes。J。Agr。Sci。 $48: 9$.

Barr, A. J. and J。H。Goodnight。1971。 Statistical analysis system. North Carolina State Univ。, Raleigh.

Blackwell, R. L. and C. R。 Hendersen, 1955. Varlation In fleece weight, weaning weight and birth weight of sheep under farm flock conditions. J. Anim. Sc1. 14:831.

Bonsma, F. N. 1939. Factors influencing the growth and development of lambs with spectal references to crossbreeding of Merino sheep in fat lamb production in South Africa. Univ. Pretorla Pub. Ser。 1 Agr。No. 48 。

Bogart, Ralph. R. C. Debaca, Lyle D。 Calvin and D. M. Nelson。 1957. Factors affecting birth weights of crossbred lambs. J。Anim. Sci. $16: 130$ 。

Boston, A. C., J.V. Whiteman and R. R. Frahm. 1973, Selection of cows for the breeding herd. Io Value of a female's own growth record. Okla. Agr. Exp。Sta. Misc. Publ. No. 89.

Bradford, G。E. 1971. Maternal effects in sheep. Presented at a symposium "The role of maternal effects in animal breeding." 63rd ASAS Annual Meeting, Univ, of Calif., Davis, Aug. 3, 1971.

Brothers, D。G。 and J. V. Whiteman。 1960. Some factors influencing milk lamb gains from 50 to 90 pounds 1ive weight. J。AnIm. Scl: 19:653 (abstr.).

Burris, M。J。 and C.A. Baugus。 1955. Milk consumption and growth of suckling lambs. J. Anim。Sci。14:186.

Butcher, R. L., R。 S。 Dunbar, Jr。 and J。A。Welch. 1964。 Heritabllities of and correlation between lamb birth weight and 140-day weight. J.Anim。Sci。23:12.

Chapman, A。B。 and J. L. Lush。 1932. Twinning, sex ratios, and genetic variability in birth welght in sheep. J. Heredity 23:473。

Christian, L。 L., E。 R. Hauser and A。 B. Chapman. 1965. Association of preweaning and postweaning traits with weaning weight in cattle。 $J$ 。 Anim. Sc1. 24:652。 
Crichton, J.A。g J。N。Aitken and A. W. Boyne. 1959。 The effect of plane of nutrition during rearing on growth, production, raproduction and health of dairy cattle. I. Growth to 24 months. An. Prod. $1: 145$.

Chrichton, J. A., J. N。Aitken and A。W. Boyne, 1960。 The effect of plane of nutrition during rearing on growth, production, reproduction and health of dairy cattle. III. Milk production during the first three lactations. An. Prod. 2:159.

Cunningham, E. P. and C. R. Henderson. 1965. Repeatability of weaning traits in beef cattle. J. Anim。Sci. 24:188。

Curnow, R。 No 1961. The estimation of repeatability and heritability from records subjected to culling。 Blometrics. 17:553。

Dun, R. B. and R. S. Grewal. 1963. A comparison of the productive performance of single and twin born Merino ewes. Aust. J。Exp。 Agric。An. Husb。 $3: 235$ 。

Ercanbrack, S. Ko and D。A.Price. 1972。 Selection for weight and rate of gain in noninbred lambs. J. Anim. Sci. 34:713.

Fredriksen, Ko R。, D. A。 Price and R. L。 Blackwell. 1967。 Environmental factors affecting rate and efficiency of gain and other traits in Rambouillet lambs. J. Anim。Sc1。26:667。

Gould, M. B. and J. V. Whiteman. 1971. Association of certain variables with the performance of spring vs, fall-born lambs. J. Anim.Sci. $33: 531$.

Guyer, P. Q. and A。 Jo. Dyer. 1954。 Study of factors affecting sheep production. Mo.Agr。Exp.Sta。Res。Bul。558。

Hansson, Artur. 1956. Influence of rearing intensity on body development and milk production。 Proc. Brit.Soc。An。Prod。1956:51。

Harrington, Rodney B. 1963. A study of some of the relationships between ewes and the growth of their lambs. Ph.D. Thesis. Oklahoma State University, Stillwater, Oklahoma.

Harrington, R。B。, Don G。 Brothers and J. V。 Whiteman。 1962。 Heritability of gain of lambs measured at different times and by different methods。J.Anim。Sc1。21:78。

Haze1, L。No and Clair E. Terrill。 1945. Heritability of weaning weight and staple length in range Rambouillet lambs。 J。Anim. Sci. $4: 347$.

Holloway, J。W. and Robert Totusek。1972. Early weaning vs。 normal weaning vs. creep-feedIng of replacement helfer calves。 okla. Agr。 Exp。Sta. Misc. Pub1. no。 87:18。 
Holtz, E。 W。 R, E. Erb and A。S.Hodgson。 1961. Relationship between rate of gain from birth to six months of age and subsequent yields of dairy cattle. J。Dairy Scl. 44:672.

Koch, R. M. 1969. Influence of Dam's environment on offspring phenotype.J。Anim. Sci. 29:108 (abstr。)。

Koch, Robert M. 1971. Maternal effects in beef cattle. Presented before the Breeding and Genetics section; 63rd Annual Meeting of the American Soclety of Animal Science, Univ. of California, Davis. Aug。1971。

Koch, R。M。 and R. T. Clark。1955. Genetic and environmental relationships among economlc characters in beef cattle. II。 Evaluating maternal environment。 J。Anim。Sci. 14:979。

Kress, D。D。 and R. J。 Burfening, 1972。 Weaning weight related to sub= sequent most probably producing ability in Hereford cows. J。 Anim. Sci. 35:327。

MacNaughton, W。N。 1957。 Repeatability and Heritability of birth, weaning and shearling weights among range sheep in Canada. Jo Sci. Iowa State College 31:465 (abstro)。

Mangus, W. L. and J。S. Brinks, 1969. Factors affecting beef cow prod= uctivity. J. Anim。Sci。29:109 (abstr。)。

Marshal1, F。 $\mathrm{R}$, and C。G。Potts。1921。 Flushing and other means of increasing lamb yields。Bul。U.S。Dept。Agric。No。996:14pp。

Munro, Joan, 1955. Studies on the milk yields of Scottish Blackface ewes. J.Agr.Sci。 $46: 131$ 。

Nelson, R. H. and Venkatchalam. 1949. Estimates of the Heritability of birth weight and weaning welght of lambs. J. Anim.Sci。 8:607 (abstro)。

Nichols, Co $W_{0}$ and J。V. Whiteman, 1966. Productivity of farm flock ewes in relation to body size. JoAnim. Sc1。 25:460。

Owen, J. B. 1957. A study of the lactation and growth of H1ll sheep in their native environment and under lowland conditions. J。Agr。Sci。 $48: 387$.

Pirchner, Franz。 1969。 Population Genetics in Animal Breeding。W。H。 Freeman and Company, San Francisco。

Plum, Mogens and Lionel Harris. 1968. Rearing intensity and milk prod= uction of Holstein heifers.J.Anim。Sci。27:1128 (abstr.).

Ray, E. E. and S。 L。 Smith。 1966。 Effect of body weight of ewes on subsequent lamb production.J。Anim。Sci。25:1172。 
Reid, J. T. 1960。 Effect of energy intake upon reproduction in farm animals。 J。 Dairy Sci。 43: Supplement, p。103。

Reid。 J。T。, J. K. Loosli。 K。 L。Turk, G。W。Trimberger, S。A。Asdell and S. E. Smith. 1957. Effect of nutrition during early life upon performance of dairy cows. Proc。Cornell Nutr。Conf。p。65.

Shelton, Maurice. 1959. Importance of size and proper development in respect to breeding performance of Rambouillet ewes. Tex. Agr。Exp. Sta. Progress Report.

Shelton, $M_{0}$ and F. Campbell。1962。 Influence of environmental adjustments on heritability of weaning welght of range Rambouillet lambs. J. Anim. Sci. 21:91。

Shelton, Maurice and JoW. Menzies。1968a. Herltability estimates of some performance characteristics of range fine-wool sheep. Research Reports, Sheep and Angora Goat, Wool and Mohair。 PR-2519。

Shelton, Maurice and J。W.Menzies, 1968b。 Repeatability and herit= ability of certain components of reproductive efficiency in finewool sheep。 Research Reports, Sheep and Angora Goat, Wool and Mohair. PR-2520.

Shrewsberry, C. L。 $F \circ N_{\circ}$ Andrews, Claude Harper and M. R. Zella。 1943 . The value of alfalfa and certain of its fractions in the nutrition of breeding ewes. J. Anim. Sci. 2:209.

Sidwe11, G。M。 and J。 O. Grandstaff。1949. Size of lambs at weaning as a permanent characteristic of Navajo ewes. JoAnim. Sc1。 8:373.

Snedecor, G。Wo and W. G. Cochran。1967。 Statistical Methods (6th ed.). Iowa State University Press, Ames, Iowa.

Sorenson, A。M. W。 Hansel, W。 H。 Hough, D。T。Armstrong, K。 McEntee and R. W. Bratton。1959。 Causes and prevention of reproductive failures in dairy cattle. I. Influence of underfeeding and overfeeding on growth and development of Holstein heifers. Cornell Agr。Exp。 Sta。Bul。936。

Stuedemann, John Alfred。 1967. Effect of nutritional level imposed from birth to eight months of age on the growth and development patterns of beef calves fed the same ration from elght months to a constant market weight. $\mathrm{Ph}$ 。D。Thesis。 Oklahoma State University, Stillwater, Oklahoma.

Swanson, E。 W。 1957. The effect of fattening dalry heifers upon their growth and lactation.J. Dairy Sci。 40:611 (abstr.)。

Swanson, E. W. 1960. Effect of rapid growth with fattening of dairy heiters on their lactational ability。J。 Dairy Sc1. 43:377。 
Swanson, E。W. 1967. Optimum growth patterns for dairy cattle. J. Dairy Sci。 50:244。

Swanson, E. W. and T。R。Spann。1954。 The effect of rapid growth with fattening upon lactation in cattle and rats. J. Anim。Sci。 13:1032 (abstr.)。

Swanson, E. W. and S。A。 Hinton。 1964。 Effect of seriously restricted growth upon lactation. J. Dairy Sci。 47:267。

Swanson, E. W., B。 J。 Bearden, E。W. Culvahouse and J。T。M1les. 1967。 Restricting growth of cattle without depressing lactation。 J。 Dairy Se1. 50:863.

Taylor, J. M. and L。 N。 Hazel。 1955。 The growth curve of pigs weaned between 134 and 174 days of age. J。Anim。Sci。14:1133。

Thrift, F. A, and J。V. Whiteman.1969. Reproductive performance of Western and Dorset $X$ Western ewes under a fall-lambing program. $J$. Anim。Sc1。28:734.

Wallace, L. R. 1948. The growth of lambs before and after birth in relation to level of nutrition. J。Agr。Scl。38:93.

Whiteman, Joe Vo. 1969。 Sheep genetics and breeding。 Presented at the Regional Extension Seminars for the Sheep Industry Development Program at San Angelo, Texas; Pocatello, Idaho; Urbana, Illinois.

Whiting, F。, S, B. Slen and L。M。Bezeau. 1952。 The quantity and quality of mature ewe's milk as influenced by the level of protein in the ration. Sci. Agr。 32:365。

Willham, R。L。 1963 The covariance between relatives for characters composed of components contributed by related individuals. Biow metrics $19: 18$ 。

Yao, T。 S. V。 I。 Simmons and R。G。 Schott. 1953. Heritability of fur characters and birth weight in Karakul lambs。J。Anim.Sci. 12:431。 
APPENDIX 
SIMPLE PHENOTYPIC CORRELATIONS BETWEEN THE EWES' BIRTH

WEIGHT AND THE BIRTH WEIGHTS OF HER LAMBS FOR

THE FOUR CLASSES OF EWES BY AGE OF DAM

\begin{tabular}{|c|c|c|c|c|c|c|c|c|c|}
\hline Dam Traits & $15 \mathrm{mo}^{\mathrm{a}}$ & $24 \mathrm{mo}$ & $36 \mathrm{mo}$. & $48 \mathrm{mo}$ & $60 \mathrm{mo}$ & $72 \mathrm{mo}$ & $84 \mathrm{mo}$. & $96 \mathrm{mo}$ & $\begin{array}{c}\text { Avg. of } A 11 \\
\text { Lambs }\end{array}$ \\
\hline \multicolumn{10}{|c|}{ Single-Reared Ewes That Lambed First At 15 Months } \\
\hline $\begin{array}{c}\mathrm{N} \\
\mathrm{Bt} . \mathrm{Wt} \text {. }\end{array}$ & $\begin{array}{l}90 \\
0.13\end{array}$ & $\begin{array}{l}81 \\
0.10\end{array}$ & $\begin{array}{l}80 \\
0.07\end{array}$ & $\begin{array}{l}72 \\
0.22\end{array}$ & $\begin{array}{l}50 \\
0.03\end{array}$ & $\stackrel{44}{-.01}$ & $\begin{array}{l}36 \\
0.12\end{array}$ & $\begin{array}{l}32 \\
0.03\end{array}$ & $\begin{array}{l}90 \\
0.09\end{array}$ \\
\hline \multirow[b]{2}{*}{ Bt. Wt. } & \multicolumn{8}{|c|}{ Twin-Reared Ewes That Lambed First At 15 Months } & \\
\hline & $\begin{array}{l}72 \\
0.13\end{array}$ & $\begin{array}{l}54 \\
0.27 *\end{array}$ & $\begin{array}{l}51 \\
0.16\end{array}$ & $\begin{array}{l}38 \\
0.33^{*}\end{array}$ & $\begin{array}{l}18 \\
0.08\end{array}$ & $\begin{array}{l}17 \\
-.03\end{array}$ & $\begin{array}{l}13 \\
0.42\end{array}$ & $\begin{array}{l}13 \\
0.27\end{array}$ & $\begin{array}{l}72 \\
0.21\end{array}$ \\
\hline \multicolumn{9}{|c|}{ Single-Reared Ewes That Lambed First At 24 Months } & \\
\hline Bt. Wt. & & $\begin{array}{l}34 \\
0.01\end{array}$ & $\begin{array}{l}36 \\
-.15\end{array}$ & $\begin{array}{l}35 \\
0.32\end{array}$ & $\stackrel{28}{-.09}$ & $\begin{array}{l}28 \\
-.13\end{array}$ & $\begin{array}{l}24 \\
0.05\end{array}$ & $\begin{array}{l}20 \\
-.13\end{array}$ & $\begin{array}{l}39 \\
0.05\end{array}$ \\
\hline & \multicolumn{8}{|c|}{ Twin-Reared Ewes That Lambed First At 24 Months } & \\
\hline Bt. Wt. & & $\begin{array}{l}39 \\
0.18\end{array}$ & $\begin{array}{l}38 \\
-.02\end{array}$ & $\begin{array}{l}26 \\
0.18\end{array}$ & $\begin{array}{l}18 \\
0.17\end{array}$ & $\begin{array}{l}18 \\
0.16\end{array}$ & $\begin{array}{l}16 \\
-.19\end{array}$ & $\stackrel{12}{-.14}$ & $\begin{array}{l}34 \\
0.06\end{array}$ \\
\hline
\end{tabular}

* Indicates correlations significantly ( $\mathrm{P}$.05) different from zero.

age of dam. 


\section{TABLE XV}

SIMPLE PHENOTYPIC CORRELATIONS BETWEEN THE EWE'S GAIN FROM BIRTH TO 70 DAYS AND THE GAIN OF HER LAMBS FROM BIRTH TO 70 DAYS, AND BETWEEN THE EWE'S 70-DAY WEIGHT AND THE 70-DAY WEIGHT OF HER LAMBS PRESENTED BY AGE OF DAM

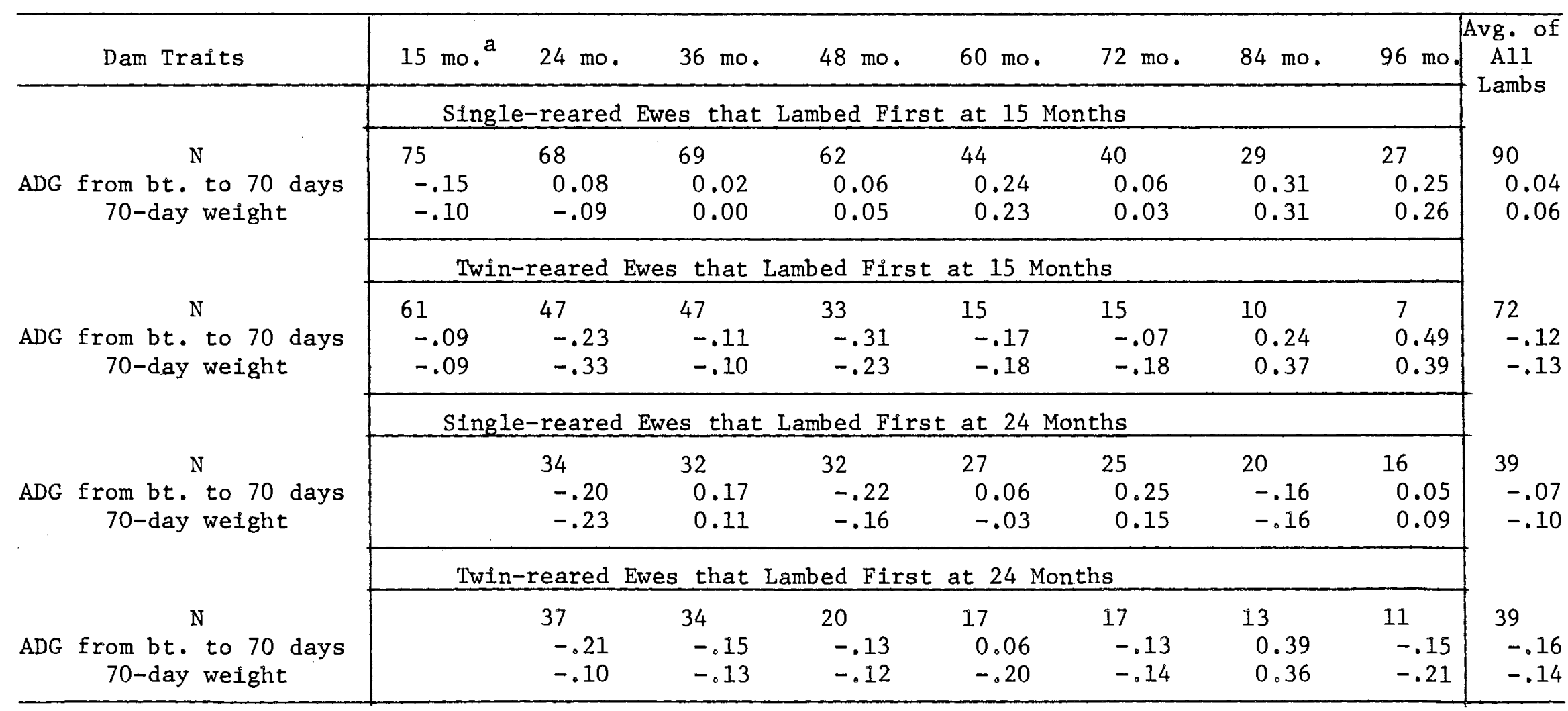

Age of Dame 


\section{TABLE XVI}

SIMPLE PHENOTYPIC CORRELATIONS BETWEEN THE EWE'S GAIN FROM BIRTH TO 70 DAYS AND THE GAIN OF HER LAMBS FROM 70 DAYS TO MARRET

PRESENTED BY AGE OF DAM

\begin{tabular}{|c|c|c|c|c|c|c|c|c|c|}
\hline Dam Traits & $15 \mathrm{mo}^{\mathrm{c}}$ & 24 mo. & $36 \mathrm{mo}$. & $48 \mathrm{mo}$. & $60 \mathrm{mo}$. & 72 mo. & $84 \mathrm{mo}$. & $90 \mathrm{mo}$. & $\begin{array}{l}\text { Avg. of } A 11 \\
\text { Lambs }\end{array}$ \\
\hline \multirow{3}{*}{ ADG bt. to 70 days } & \multicolumn{8}{|c|}{ Single-reared Ewes that Lambed First at 15 Months } & \multirow{3}{*}{$\begin{array}{l}90 \\
0.07\end{array}$} \\
\hline & $\begin{array}{l}70 \\
0.03\end{array}$ & $\begin{array}{l}65 \\
-.02\end{array}$ & $\begin{array}{l}64 \\
-.11\end{array}$ & $\begin{array}{l}61 \\
0.10\end{array}$ & $\begin{array}{l}44 \\
0.36 *\end{array}$ & $\begin{array}{l}40 \\
0.02\end{array}$ & $\begin{array}{l}29 \\
0.07\end{array}$ & $\begin{array}{l}25 \\
0.01\end{array}$ & \\
\hline & & Twin- & ared Ew & that $\mathrm{L}$ & ed Firs & at $15 \mathrm{M}$ & ths & & \\
\hline \multirow[t]{2}{*}{ ADG bt. to 70 days } & $\begin{array}{l}57 \\
0.05\end{array}$ & $\begin{array}{l}46 \\
0.07\end{array}$ & $\begin{array}{l}47 \\
-.08\end{array}$ & $\stackrel{33}{-.11}$ & ${ }_{-.07^{b}}^{15}$ & $\stackrel{15}{-.02}$ & $\begin{array}{l}10 \\
-.02\end{array}$ & $\begin{array}{l}7 \\
-.38\end{array}$ & \multirow[t]{2}{*}{$\begin{array}{l}72 \\
0.06\end{array}$} \\
\hline & \multicolumn{8}{|c|}{ Single-reared Ewes that Lambed First at 24 Months } & \\
\hline \multirow[t]{2}{*}{ ADG bt. to 70 days } & & $\begin{array}{l}24 \\
-.11\end{array}$ & $\begin{array}{l}29 \\
-.03\end{array}$ & ${ }^{32} 0.07^{a}$ & $\begin{array}{l}27 \\
0.13\end{array}$ & $\stackrel{25}{-.04}$ & $\begin{array}{l}19 \\
0.00\end{array}$ & $\begin{array}{l}15 \\
0.13\end{array}$ & \multirow[t]{2}{*}{$\begin{array}{l}39 \\
0.05\end{array}$} \\
\hline & \multicolumn{8}{|c|}{ Twin-reared Ewes that Lambed First at 24 Months } & \\
\hline ADG bt. to 70 days & & $\begin{array}{l}37 \\
-.07\end{array}$ & $\begin{array}{l}30 \\
0.08\end{array}$ & ${ }^{20}-.29^{b}$ & $\begin{array}{l}17 \\
0.17\end{array}$ & $\stackrel{17}{-.19}$ & $\begin{array}{l}12 \\
0.05\end{array}$ & $\begin{array}{l}11 \\
0.33\end{array}$ & $\begin{array}{l}39 \\
-.04\end{array}$ \\
\hline
\end{tabular}

${ }^{a b}$ Coefficients within a column between single and twin-reared dams within each age of dam at first lambing are different $(P<.05)$.

Significantly $(P<.05)$ different from zero.

$c$ Age of dam. 
SIMPLE PHENOTYPIC CORRELATIONS BETWEEN THE EWE'S BIRTH WEIGHT AND HER LAMB'S BIRTH WEIGHTS, THE EWE'S GAIN FROM BIRTH TO 70 DAYS AND THE CORRESPONDING GAIN OF HER LAMBS, THE EWE'S 70-DAY WEIGHT AND THE 70-DAY WEIGHT OF HER LAMBS, THE EWE'S GAIN FROM BIRTH TO 70 DAYS AND THE POST-WEANING GAIN OF HER LAMBS (POOLED OVER AGE OF EWE AT FIRST LAMBING) FOR SINGLE AND TWIN-REARED EWES BY AGE OF DAM

\begin{tabular}{|c|c|c|c|c|c|c|c|c|c|c|c|c|c|c|c|c|c|c|}
\hline Dam Trafts & mo. $^{2}$ & mo. & $\begin{array}{l}24 \\
\text { mo. }^{a}\end{array}$ & $\begin{array}{c}24 \\
\text { mo. }\end{array}$ & $36{ }_{\text {mo. }}{ }^{3}$ & $\begin{array}{l}36 \\
\text { mo. }\end{array}$ & mo. $^{a}$ & $\begin{array}{c}48 \\
\text { mo. }\end{array}$ & $\begin{array}{l}60 \\
\text { mo. }^{a}\end{array}$ & $\begin{array}{l}60 \\
\text { mo. }\end{array}$ & $\begin{array}{l}72 \\
\text { mo. }\end{array}$ & $\begin{array}{l}72 \\
\text { mo. }\end{array}$ & $\begin{array}{l}84 \\
\text { mo. }^{a}\end{array}$ & $\begin{array}{l}84 \\
\mathrm{mo}\end{array}$ & $\begin{array}{l}90 \\
\text { mo. }^{\mathrm{a}}\end{array}$ & $\begin{array}{l}90 \\
\text { mo. }\end{array}$ & $\begin{array}{c}\text { Avg. of A11 } \\
\text { Lambs }\end{array}$ & $\begin{array}{c}\text { Avg. of A11 } \\
\text { Lambs }\end{array}$ \\
\hline \multicolumn{19}{|c|}{ Lamb Birth Weight } \\
\hline $\begin{array}{l}\mathrm{N}^{\mathrm{c}} \\
\text { Bfrth Wefght }\end{array}$ & $\begin{array}{l}90 \\
0.07\end{array}$ & $\begin{array}{c}72 \\
0.15\end{array}$ & $\begin{array}{l}120 \\
0.01\end{array}$ & $\begin{array}{l}91 \\
0.15\end{array}$ & $\begin{array}{l}116 \\
0.11\end{array}$ & $\begin{array}{c}89 \\
0.16\end{array}$ & $\begin{array}{l}107 \\
0.12\end{array}$ & $\begin{array}{c}64 \\
0.23\end{array}$ & $\stackrel{78}{-.04}$ & $\begin{array}{l}36 \\
0.12\end{array}$ & $\begin{array}{l}72 \\
0.00\end{array}$ & $\begin{array}{l}35 \\
-.10\end{array}$ & $\begin{array}{l}70 \\
0.04\end{array}$ & $\begin{array}{c}29 \\
0.26\end{array}$ & $\stackrel{52}{0.03}$ & $\begin{array}{l}25 \\
0.27\end{array}$ & $\begin{array}{l}129 \\
0.05\end{array}$ & $\begin{array}{l}111 \\
0.16\end{array}$ \\
\hline \multicolumn{19}{|c|}{ Lamb Gain From Birth to 70 Days } \\
\hline $\begin{array}{l}\mathrm{N}^{\mathrm{c}} \\
\text { Avg. Dafly } \\
\text { Gafn Birth } \\
\text { to } 70 \text { Days }\end{array}$ & $\begin{array}{l}75 \\
-.17\end{array}$ & $\begin{array}{l}61 \\
-.12\end{array}$ & $\begin{array}{r}102 \\
0.06\end{array}$ & $\begin{array}{l}84 \\
-.20\end{array}$ & $\begin{array}{l}101 \\
-.03\end{array}$ & $\begin{array}{l}81 \\
-.09\end{array}$ & $\begin{array}{l}94 \\
0.11\end{array}$ & $\begin{array}{l}53 \\
-.13 \\
\end{array}$ & $\begin{array}{l}71 \\
0.24^{*}\end{array}$ & $\begin{array}{l}32 \\
-.14\end{array}$ & $\begin{array}{l}65 \\
0.04\end{array}$ & $\begin{array}{l}32 \\
0.21\end{array}$ & $\begin{array}{l}49 \\
0.20\end{array}$ & $\begin{array}{l}23 \\
-.08\end{array}$ & $\begin{array}{l}43 \\
0.25\end{array}$ & $\begin{array}{l}18 \\
0.48 *\end{array}$ & $\begin{array}{l}129 \\
0.00\end{array}$ & $\begin{array}{l}111 \\
-.12\end{array}$ \\
\hline \multicolumn{19}{|c|}{ Lamb 70-Day Weight } \\
\hline $\begin{array}{c}\mathrm{N}^{\mathrm{c}} \\
70-\text { Day } \\
\text { Weight }\end{array}$ & $\begin{array}{l}75 \\
-.11\end{array}$ & $\begin{array}{l}61 \\
-.04\end{array}$ & $\begin{array}{l}102 \\
0.09\end{array}$ & $\begin{array}{l}84 \\
-.18\end{array}$ & $\begin{array}{l}101 \\
-.02\end{array}$ & $\begin{array}{l}81 \\
-.05\end{array}$ & $\begin{array}{l}94 \\
0.07\end{array}$ & $\begin{array}{l}53 \\
-.10\end{array}$ & $\begin{array}{l}71 \\
0.19\end{array}$ & $\begin{array}{l}32 \\
-.14\end{array}$ & $\begin{array}{l}65 \\
0.04\end{array}$ & $\begin{array}{l}32 \\
0.24\end{array}$ & $\begin{array}{l}49 \\
0.19\end{array}$ & $\begin{array}{l}23 \\
-.11\end{array}$ & $\begin{array}{l}43 \\
0.28\end{array}$ & $\begin{array}{l}18 \\
0.40 *\end{array}$ & $\begin{array}{l}129 \\
0.03\end{array}$ & $\begin{array}{l}111 \\
-.08\end{array}$ \\
\hline \multicolumn{19}{|c|}{ Lamb Gain From 70 Days to Market } \\
\hline $\begin{array}{l}\mathrm{N}^{\mathrm{c}} \\
\text { Avg. Daily } \\
\text { Gafn Birth } \\
\text { to } 70 \text { Days }\end{array}$ & $\begin{array}{l}70 \\
-.03\end{array}$ & $\begin{array}{l}57 \\
-.01\end{array}$ & $\begin{array}{l}99 \\
0.00\end{array}$ & $\begin{array}{l}83 \\
0.09\end{array}$ & $\begin{array}{l}93 \\
-.12\end{array}$ & $\begin{array}{l}77 \\
-.05\end{array}$ & $\begin{array}{l}93 \\
0.06\end{array}$ & $\begin{array}{c}53 \\
0.10\end{array}$ & $\begin{array}{l}71 \\
0.23\end{array}$ & 32 & $\begin{array}{l}65 \\
-.04\end{array}$ & $\begin{array}{l}32 \\
0.13\end{array}$ & $\begin{array}{l}48 \\
0.12\end{array}$ & $\begin{array}{l}22 \\
0.09\end{array}$ & $\begin{array}{l}40 \\
0.09\end{array}$ & $\begin{array}{l}18 \\
-.18\end{array}$ & $\begin{array}{l}129 \\
0.09\end{array}$ & $\begin{array}{l}111 \\
-.02\end{array}$ \\
\hline
\end{tabular}

${ }^{\star}$ Significantly $(P<.05)$ different from zero

${ }^{\text {a }}$ Single-reared ewes

$b_{\text {Tw1n-reared ewes }}$

${ }^{c}$ The number of dam and offspring records comprising each correlation coefficient estimate

$\square$ Correlation coefficients in the same box are different $(P<.05)$ from each other 
TABLE XVIII

SIMPLE PHENOTYPIC CORRELATION COEFFICIENTS BETWEEN EWE GAIN FROM

BIRTH TO 70 DAYS AND GAIN OF HER LAMBS FROM 70 DAYS TO MARKET

POOLED OVER AGE OF DAM AT FIRST LAMBING AND OVER DAM

TYPE OF REARING AND PRESENTED BY AGE OF DAM

\begin{tabular}{c|rrrrrrrrr}
\hline & \multicolumn{1}{c}{ Age of Dam in Months } \\
\cline { 2 - 9 } & 15 & 24 & 36 & 48 & 60 & 72 & 84 & $\begin{array}{c}\text { Avg. of } \\
\text { Al1 Lambs }\end{array}$ \\
\hline \multirow{2}{*}{$\begin{array}{l}\text { N } \\
\text { Correlation } \\
\text { Coefficients }\end{array}$} & 0.00 & 0.01 & -.11 & 0.06 & -.01 & -.02 & $0.32 *$ & -.01 & 0.08 \\
\hline
\end{tabular}

* Significantly $(P<.05)$ different from zero. 
TABLE XIX

MEANS (LEAST SQUARES) BY YEAR OF BIRTH FOR EWE BIRTH WEIGHTS, GAINS FROM BIRTH

TO 70 DAYS AND 70-DAY WEIGHTS FOR THE DAMS IN THIS STUDY

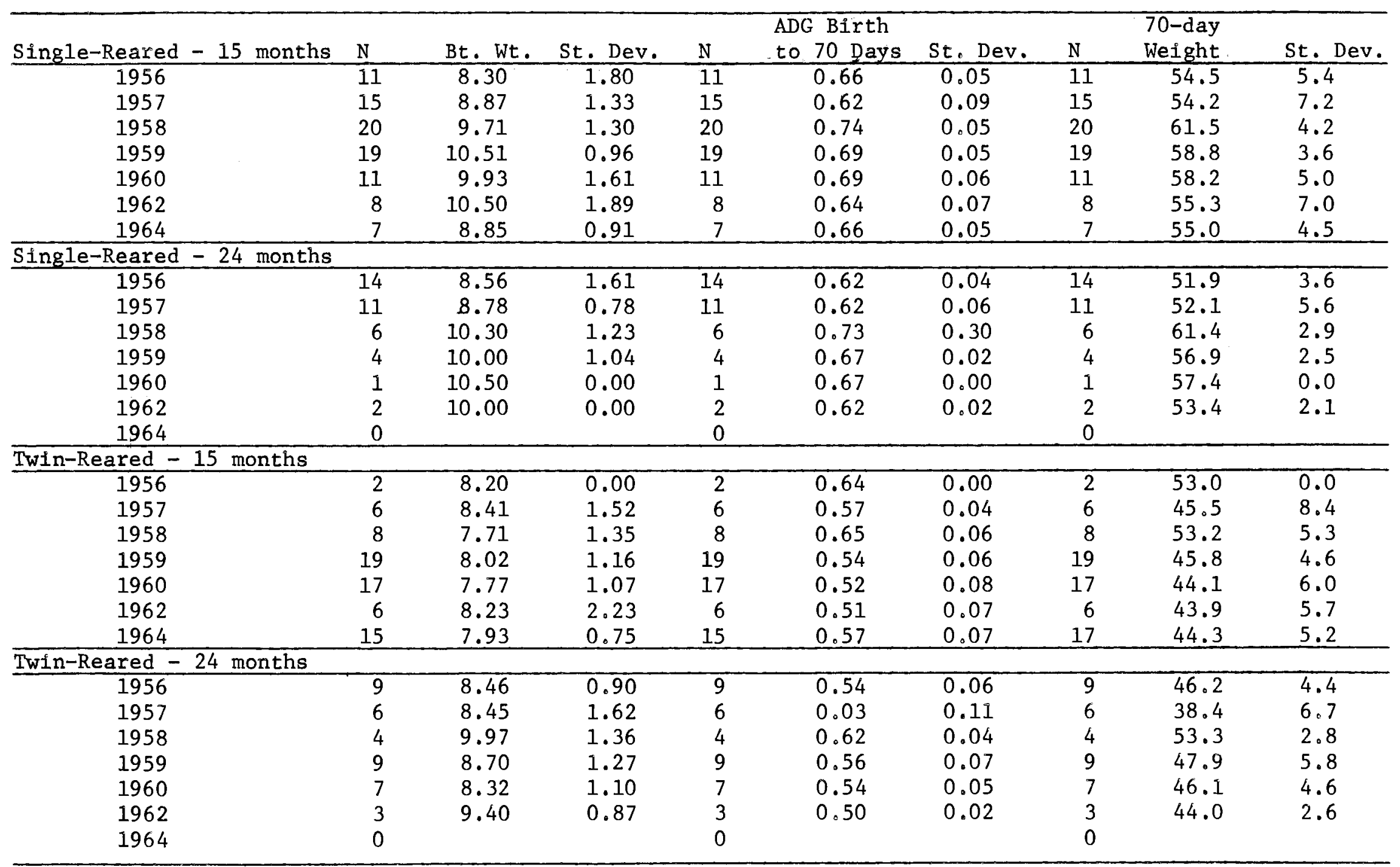


TABLE XX

ANALYSIS OF VARIANCE OF BIRTH WEIGHT FOR THE LAMBS BORN TO THE SINGLE AND TWIN-REARED DAMS

\begin{tabular}{|c|c|c|c|c|c|}
\hline Source & D.F. & S.S. & M.S. & $\begin{array}{c}\text { "F" } \\
\text { Value }\end{array}$ & $\begin{array}{l}\text { Prob。 } \\
\text { "F" }\end{array}$ \\
\hline Total & 1612 & & & & \\
\hline $\begin{array}{l}\text { Dam Type } \\
\text { of Rearing }\end{array}$ & 1 & 0.0708 & 0.07 & 0.02 & 0.87 \\
\hline $\begin{array}{l}\text { Dam Age } \\
\text { at 1st Lamb }\end{array}$ & 1 & 19.4725 & 19.47 & 6.57 & 0.01 \\
\hline Error & 1610 & 4765.9188 & 2.96 & & \\
\hline
\end{tabular}


TABLE XXI

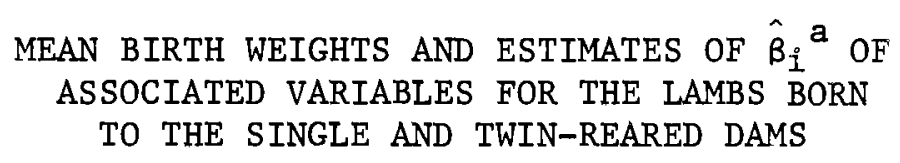

\begin{tabular}{|c|c|c|c|c|}
\hline $\begin{array}{l}\text { Source of Variation } \\
\text { (Associated Variables) }\end{array}$ & $\begin{array}{c}\hat{\beta} \\
\text { Values }\end{array}$ & $\begin{array}{l}\text { Difference } \\
\left(\hat{\beta}_{1}-\hat{\beta}_{2}\right)\end{array}$ & $\begin{array}{l}\text { "t" } \\
\text { Value }\end{array}$ & $\begin{array}{l}\text { Prob.> } \\
|\mathrm{t}|\end{array}$ \\
\hline $\begin{array}{l}\text { Dam Type of Rearing: } \hat{\beta}_{1} \\
\text { Single-Reared: } \hat{B}_{11}\end{array}$ & 0.01 & 0.02 & 0.32 & 0.74 \\
\hline Twin-Reared: $\hat{\beta}_{12}$ & -.01 & & & \\
\hline $\begin{array}{l}\text { Dam Age at 1st Lambing: } \hat{\beta}_{2} \\
15 \text { mo.: } \hat{\beta}_{21}\end{array}$ & -.11 & -.22 & 2.56 & 0.01 \\
\hline 24 mo.: $\hat{\beta}_{22}$ & 0.11 & & & \\
\hline Mean $(\mu)$ & 4 & & & \\
\hline
\end{tabular}

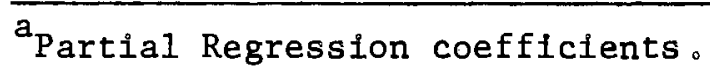

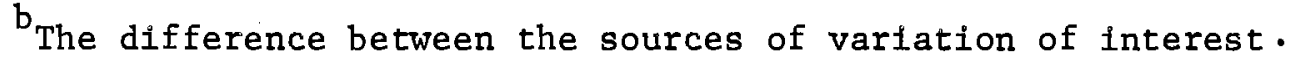


TABLE XXII

ANALYSIS OF VARIANCE OF GAIN FROM BIRTH TO 70 DAYS OF THE LAMBS BORN TO THE SINGLE AND TWIN-REARED DAMS

\begin{tabular}{|c|c|c|c|c|c|}
\hline Source & D.F. & S.S. & M.S. & "F" Value & $\begin{array}{c}\text { Prob_> } \\
\text { "F"" }\end{array}$ \\
\hline Total & 1355 & & & & \\
\hline $\begin{array}{l}\text { Dam Type } \\
\text { of Rearing }\end{array}$ & 1 & 0.0025 & 0.0025 & 0.23 & 0.63 \\
\hline $\begin{array}{l}\text { Age of Dam } \\
\text { At 1st Lambing }\end{array}$ & 1 & 0.0205 & 0.0205 & 1.88 & 0.19 \\
\hline Error & 1353 & 14.7324 & 0.0108 & & \\
\hline
\end{tabular}


TABLE XXIII

MEAN GAIN FROM BIRTH TO 70 DAYS AND ESTIMATES OF $\hat{\beta}_{1}{ }^{a}$ OF ASSOCIATED VARIABLES FOR THE LAMBS BORN TO THE SINGLE AND TWIN-REARED DAMS

\begin{tabular}{|c|c|c|c|c|}
\hline $\begin{array}{l}\text { Source of Variation } \\
\text { (Associated Variables) }\end{array}$ & $\begin{array}{c}\hat{\beta}_{1} \\
\text { Values }\end{array}$ & $\begin{array}{c}\text { Difference } \\
\left(\beta_{1}-\beta_{2}\right)\end{array}$ & $\begin{array}{c}\text { "t" } \\
\text { Value }\end{array}$ & $\begin{array}{l}\text { Prob.> } \\
|t|\end{array}$ \\
\hline $\begin{array}{l}\text { Dam Type of Rearing: } \\
\text { Single-Reared: } \hat{\beta}_{11} \\
\text { Twin-Reared: } \hat{\beta}_{12}\end{array}$ & $\begin{array}{l}-.001 \\
0.001\end{array}$ & -.002 & 0.56 & 0.58 \\
\hline $\begin{array}{l}\text { Dam Age at lst Lambing: } \\
\qquad \begin{array}{l}15 \text { mo.: } \\
24 \text { mo.: }\end{array} \hat{\beta}_{22}\end{array}$ & $\begin{array}{l}-.004 \\
0.004\end{array}$ & -.008 & 1.37 & 0.19 \\
\hline Mean $(\mu)$ & 0.61 & nds per day & & \\
\hline
\end{tabular}

a Partial regression coefficients. 
TABLE XXIV

ANALYSIS OF VARIANCE OF 70-DAY WEIGHT OF THE LAMBS BORN TO THE SINGLE AND TWIN-REARED DAMS

\begin{tabular}{|c|c|c|c|c|c|}
\hline Source & D.F. & S.S. & M.S. & "F" Value & $\begin{array}{l}\text { Prob。 } \\
\text { "F"" }\end{array}$ \\
\hline Total & 1355 & & & & \\
\hline $\begin{array}{r}\text { Dam Type } \\
\text { of Rearing }\end{array}$ & 1 & 9.3391 & 9.3391 & 0.14 & 0.70 \\
\hline $\begin{array}{l}\text { Age of Dam } \\
\text { At 1st Lambing }\end{array}$ & 1 & 30.9692 & 30.9692 & 0.49 & 0.51 \\
\hline Error & 1353 & 84724.6650 & & & \\
\hline
\end{tabular}


TABLE XXV

MEAN 70-DAY WEIGHT AND ESTIMATES OF $\hat{\beta}_{i}^{a}$ OF ASSOCIATED VARIABLES FOR THE LAMBS BORN

TO THE SINGLE AND TWIN-REARED DAMS

\begin{tabular}{|c|c|c|c|c|}
\hline $\begin{array}{l}\text { Sources of Variation } \\
\text { (Associated Variables) }\end{array}$ & Valùes & $\begin{array}{c}\text { Difference } \\
\left(\hat{\beta}_{1}-\hat{\beta}_{2}\right)\end{array}$ & $\begin{array}{l}\text { "t" } \\
\text { Value }\end{array}$ & Prob. \\
\hline \multicolumn{5}{|l|}{ Dam type of rearing: $\hat{B}_{1}$} \\
\hline Single-reared: $\hat{\beta}_{11}$ & -.09 & -.18 & 0.42 & 0.67 \\
\hline Twin-reared: $\hat{\beta}_{12}$ & 0.09 & & & \\
\hline \multicolumn{5}{|c|}{ Dam age at 1st lambing: $\hat{B}_{2}$} \\
\hline 15 mo.: $\hat{\beta}_{21}$ & -.15 & -.30 & 0.70 & 0.51 \\
\hline $24 \mathrm{mo} \cdot: \hat{\beta}_{22}$ & 0.15 & & & \\
\hline Mean $(\mu)$ & 51.48 & & & \\
\hline
\end{tabular}

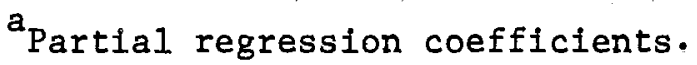


TABLE XXVI

ANALYSIS OF VARIANCE OF GAIN FROM 70 DAYS TO MARKET OF THE LAMBS BORN TO THE SINGLE AND TWIN-REARED DAMS

\begin{tabular}{lrrrrr}
\hline Source & D.F. & S.S. & M.S. & "F" Value & $\begin{array}{c}\text { Prob.> } \\
\text { "F" }\end{array}$ \\
\hline Total & 1285 & & & & \\
$\begin{array}{l}\text { Dam Type } \\
\text { of Rearing }\end{array}$ & 1 & 0.0147 & 0.0147 & 1.18 & 0.27 \\
$\begin{array}{l}\text { Age of Dam } \\
\text { At lst Lambing }\end{array}$ & 1 & 0.0036 & 0.0036 & 0.29 & 0.59 \\
Error & 1283 & 16.0045 & & & \\
\hline
\end{tabular}


TABLE XXVII

MEAN GAIN FROM 70 DAYS TO MARKET AND ESTIMATED $\hat{\beta}_{i}{ }^{a}$ OF ASSOCIATED VARIABLES FOR THE LAMBS BORN TO THE SINGLE AND TWIN-REARED DAMS

\begin{tabular}{|c|c|c|c|c|}
\hline $\begin{array}{l}\text { Sources of Variation } \\
\text { (Associated Variables) }\end{array}$ & $\begin{array}{c}\hat{\beta}_{i} \\
\text { Values }\end{array}$ & $\begin{array}{r}\text { Difference } \\
\left(\hat{\beta}_{1}-\hat{\beta}_{2}\right)\end{array}$ & $\begin{array}{l}\text { "t" } \\
\text { Value }\end{array}$ & $\begin{array}{c}\text { Prob. } \\
|t|\end{array}$ \\
\hline \multicolumn{5}{|l|}{ Dam type of rearing: $\hat{\beta}_{1}$} \\
\hline Single-reared: $\hat{\beta}_{11}$ & 0.003 & 0.006 & 1.05 & 0.29 \\
\hline Twin-reared: $\hat{\beta}_{12}$ & -.003 & & & \\
\hline \multicolumn{5}{|c|}{ Dam age at lst lambing: $\hat{\beta}_{2}$} \\
\hline 15 mo. $: \hat{\beta}_{21}$ & 0.001 & 0.002 & 0.54 & 0.59 \\
\hline $24 \mathrm{mo}:: \hat{\beta}_{22}$ & -.001 & & & \\
\hline Mean $(\mu)$ & $0.54 \mathrm{pc}$ & ds per day & & \\
\hline
\end{tabular}

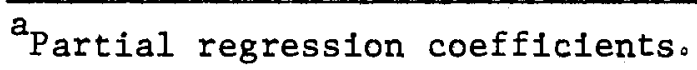


MEAN (LEAST SQUARES) LAMB BIRTH WEIGHTS AND SUBSEQUENT PERFORMANCE TO MARKET OF LAMBS BORN TO THE SINGLE AND TWIN-REARED DAMS LAMBING FIRST

FIRST AT 15 AND 24 MONTHS

\begin{tabular}{|c|c|c|c|c|c|c|c|c|c|}
\hline & 15 mo. & 24 шо. & 36 mo. & 48 mo. & 60 mo. & 72 шо. & 84 mo. & 96 mo. & $\begin{array}{c}\text { Avg. of } \\
\text { Ail } \\
\text { Lambs }\end{array}$ \\
\hline Ewe Group & \multicolumn{9}{|c|}{ Birth Weight } \\
\hline $\begin{array}{l}\text { Twin } 24^{\mathrm{a}} \\
\text { Single } 24^{\mathrm{b}}\end{array}$ & & $\begin{array}{l}8.54 \pm .15 \\
8.62 \pm .14\end{array}$ & $\begin{array}{l}8.96 \pm .14 \\
8.90 \pm .12\end{array}$ & $\begin{array}{l}9.16 \pm .23 \\
9.00 \pm .13\end{array}$ & $\begin{array}{l}9.47 \pm .23 \\
8.93 \pm .17\end{array}$ & $\begin{array}{l}9.47 \pm .17 \\
9.16 \pm .20\end{array}$ & $\begin{array}{l}8.99 \pm .21 \\
8.78 \pm .16\end{array}$ & $\begin{array}{r}9.33 \pm .13 \\
10.41 \pm .17\end{array}$ & $\begin{array}{l}8.87 \pm .12 \\
9.08 \pm .09\end{array}$ \\
\hline $\begin{array}{l}\text { Single } 15^{c} \\
\text { Twtn 15d }\end{array}$ & $\begin{array}{l}8.27 \pm .16 \\
8.41 \pm .17\end{array}$ & $\begin{array}{l}8.52 \pm .19 \\
8.69 \pm .18\end{array}$ & $\begin{array}{l}8.77 \pm .17 \\
8.85 \pm .15\end{array}$ & $\begin{array}{l}8.90 \pm .15 \\
8.92 \pm .13\end{array}$ & $\begin{array}{l}8.82 \pm .14 \\
9.21 \pm .18\end{array}$ & $\begin{array}{l}9.57 \pm .14 \\
9.48 \pm .19\end{array}$ & $\begin{array}{l}8.92 \pm .14 \\
8.76 \pm .18\end{array}$ & $\begin{array}{r}9.80 \pm .14 \\
10.83 \pm .16\end{array}$ & $\begin{array}{l}8.66 \pm .10 \\
8.85 \pm .11\end{array}$ \\
\hline \multicolumn{10}{|c|}{ Avg. Daily Gain From Birth to 70 Days } \\
\hline $\begin{array}{l}\text { Twin } 24 \\
\text { Single } 24\end{array}$ & & $\begin{array}{l}.56 \pm .011 \\
.56 \pm .009\end{array}$ & $\begin{array}{l}.60 \pm .009 \\
.61 \pm .009\end{array}$ & $\begin{array}{l}.65 \pm .007 \\
.61 \pm .008\end{array}$ & $\begin{array}{l}.63 \pm .008 \\
.61 \pm .010\end{array}$ & $\begin{array}{l}.63 \pm .011 \\
.61 \pm .007\end{array}$ & $\begin{array}{l}.63 \pm .012 \\
.61 \pm .007\end{array}$ & $\begin{array}{l}.63 \pm .008 \\
.67 \pm .007\end{array}$ & $\begin{array}{l}.60 \pm .007 \\
.60 \pm .007\end{array}$ \\
\hline $\begin{array}{l}\text { Single } 15 \\
\text { Twin } 15\end{array}$ & $\begin{array}{l}.54 \pm .011 \\
.57 \pm .013\end{array}$ & $\begin{array}{l}.58 \pm .009 \\
.58 \pm .008\end{array}$ & $\begin{array}{l}.61 \pm .010 \\
.63 \pm .009\end{array}$ & $\begin{array}{l}.65 \pm .005 \\
.65 \pm .006\end{array}$ & $\begin{array}{l}.61 \pm .009 \\
.62 \pm .010\end{array}$ & $\begin{array}{l}.63 \pm .010 \\
.64 \pm .010\end{array}$ & $\begin{array}{l}.63 \pm .009 \\
.60 \pm .009\end{array}$ & $\begin{array}{l}.65 \pm .009 \\
.64 \pm .008 \\
\end{array}$ & $\begin{array}{l}.59 \pm .007 \\
.61 \pm .008 \\
\end{array}$ \\
\hline \multicolumn{10}{|c|}{ 70-Day Weight } \\
\hline $\begin{array}{l}\text { Twin } 24 \\
\text { Single } 24\end{array}$ & & $\begin{array}{l}47.7 \pm .77 \\
47.8 \pm .70\end{array}$ & $\begin{array}{l}50.8 \pm .66 \\
51.6 \pm .71\end{array}$ & $\begin{array}{l}52.3 \pm .56 \\
51.7 \pm .51\end{array}$ & $\begin{array}{l}53.2 \pm .67 \\
51.6 \pm .79\end{array}$ & $\begin{array}{l}53.5 \pm .75 \\
52.3 \pm .65\end{array}$ & $\begin{array}{l}53.0 \pm .92 \\
51.4 \pm .58\end{array}$ & $\begin{array}{l}53.4 \pm .69 \\
57.3 \pm .57\end{array}$ & $\begin{array}{l}50.8 \pm .52 \\
51.8 \pm .51\end{array}$ \\
\hline $\begin{array}{l}\text { Single } 15 \\
\text { Twin } 15\end{array}$ & $\begin{array}{l}46.0 \pm .87 \\
48.3 \pm .99\end{array}$ & $\begin{array}{l}49.1 \pm .64 \\
49.2 \pm .99\end{array}$ & $\begin{array}{l}51.4 \pm .82 \\
52.9 \pm .68\end{array}$ & $\begin{array}{l}54.5 \pm .46 \\
54.5 \pm .50\end{array}$ & $\begin{array}{l}51.6 \pm .75 \\
52.6 \pm .79\end{array}$ & $\begin{array}{l}53.6 \pm .73 \\
54.2 \pm .50\end{array}$ & $\begin{array}{l}53.0 \pm .71 \\
50.7 \pm .73\end{array}$ & $\begin{array}{l}55.3 \pm .64 \\
55.6 \pm .52 \\
\end{array}$ & $\begin{array}{l}49.9 \pm .59 \\
51.5 \pm .57 \\
\end{array}$ \\
\hline \multicolumn{10}{|c|}{ Avg. Dafly Gain From 70 Days to Market } \\
\hline $\begin{array}{l}\text { Twin } 24 \\
\text { Single } 24\end{array}$ & & $\begin{array}{l}.52 \pm .010 \\
.50 \pm .010\end{array}$ & $\begin{array}{l}.51 \pm .010 \\
.52 \pm .009\end{array}$ & $\begin{array}{l}.53 \pm .006 \\
.53 \pm .011\end{array}$ & $\begin{array}{l}.53 \pm .012 \\
.50 \pm .010\end{array}$ & $\begin{array}{l}.57 \pm .008 \\
.54 \pm .009\end{array}$ & $\begin{array}{l}.58 \pm .009 \\
.58 \pm .007\end{array}$ & $\begin{array}{l}.52 \pm .013 \\
.59 \pm .009\end{array}$ & $\begin{array}{l}.53 \pm .006 \\
.53 \pm .005\end{array}$ \\
\hline $\begin{array}{l}\text { Single } 15 \\
\text { Twin } 15\end{array}$ & $\begin{array}{l}.49 \pm .013 \\
.47 \pm .011\end{array}$ & $\begin{array}{l}.51 \pm .010 \\
.52 \pm .008\end{array}$ & $\begin{array}{l}.54 \pm .010 \\
.53 \pm .009\end{array}$ & $\begin{array}{l}.53 \pm .010 \\
.59 \pm .010\end{array}$ & $\begin{array}{l}.55 \pm .010 \\
.57 \pm .011\end{array}$ & $\begin{array}{l}.56 \pm .002 \\
.62 \pm .010\end{array}$ & $\begin{array}{l}.56 \pm .007 \\
.55 \pm .005\end{array}$ & $\begin{array}{l}.61 \pm .010 \\
.59 \pm .007\end{array}$ & $\begin{array}{l}.51 \pm .007 \\
.50 \pm .009\end{array}$ \\
\hline
\end{tabular}

Twin-reared dams that lambed first at 24 months

bingle-reared dams that lambed first at 24 months

csingle-reared dams that lambed first at 15 months

$\mathrm{d}_{\text {Twin-reared dams that lambed first at } 15 \text { months }}$ 
TABLE XXIX

MEAN (LEAST SQUARES) BIRTH WEIGHTS AND SUBSEQUENT PERFORMANCE TO MARKET OF LAMBS BORN TO THE SINGLE AND TWIN-REARED DAMS

\begin{tabular}{|c|c|c|c|c|c|c|c|c|c|}
\hline Age of Dam & $15 \mathrm{mo}$. & 24 mo. & 36 mo. & 48 mo. & 60 mo. & $72 \mathrm{mo.}$ & 84 mo. & $96 \mathrm{mo}$. & Avg. of All Lambs \\
\hline \multicolumn{10}{|l|}{ Ewe Traft } \\
\hline Single & $8.27 \pm .15$ & $8.70 \pm .17$ & $8.91 \pm .16$ & $8.91 \pm .15$ & $9.10 \pm .17$ & $9.29 \pm .17$ & $9.45 \pm .17$ & $9.80 \pm .14$ & $8.78 \pm .10$ \\
\hline Twin & $8.41 \pm .16$ & $8.70 \pm .17$ & $8.89 \pm .15$ & $8.99 \pm .17$ & $9.24 \pm .18$ & $9.24 \pm .20$ & $9.23 \pm .15$ & $10.80 \pm .17$ & $8.82 \pm .11$ \\
\hline \multicolumn{10}{|c|}{ Avg. Daily Gain from B1rth to 70 Days } \\
\hline $\begin{array}{l}\text { Single } \\
\text { Twin }\end{array}$ & $\begin{array}{l}.54^{a}{ }_{ \pm}^{ \pm} .010 \\
.57^{b_{ \pm}} .012\end{array}$ & $\begin{array}{l}.59 \pm .010 \\
.61 \pm .009\end{array}$ & $\begin{array}{l}.62 \pm .009 \\
.63 \pm .008\end{array}$ & $\begin{array}{l}.64 \pm .007 \\
.64 \pm .008\end{array}$ & $\begin{array}{l}.62 \pm .009 \\
.63 \pm .010\end{array}$ & $\begin{array}{l}.62 \pm .009 \\
.62 \pm .011\end{array}$ & $\begin{array}{l}.63 \pm .008 \\
.62 \pm .008\end{array}$ & $\begin{array}{l}.65 \pm .008 \\
.64 \pm .007\end{array}$ & $\begin{array}{l}.60 \pm .007 \\
.61 \pm .008\end{array}$ \\
\hline \multicolumn{10}{|c|}{ 70-Day Weight } \\
\hline $\begin{array}{l}\text { Single } \\
\text { Tw1n }\end{array}$ & $\begin{array}{l}46.0^{a} \pm .82 \\
48.3^{b} \pm .91\end{array}$ & $\begin{array}{l}50.0 \pm .78 \\
51.4 \pm .71\end{array}$ & $\begin{array}{l}52.3 \pm .73 \\
53.0 \pm .65\end{array}$ & $\begin{array}{l}53.7 \pm .59 \\
53.7 \pm .56\end{array}$ & $\begin{array}{l}51.8 \pm .71 \\
51.9 \pm .76\end{array}$ & $\begin{array}{l}52.6 \pm .68 \\
53.3 \pm .73\end{array}$ & $\begin{array}{l}53.5 \pm .68 \\
52.6 \pm .71\end{array}$ & $\begin{array}{l}55.3 \pm .64 \\
55.6 \pm .52\end{array}$ & $\begin{array}{l}50.0 \pm .57 \\
51.0 \pm .56\end{array}$ \\
\hline \multicolumn{10}{|c|}{ Avg. Daily Gain from 70 Days to Market } \\
\hline $\begin{array}{l}\text { Single } \\
\text { Twin }\end{array}$ & $\begin{array}{l}.49 \pm .013 \\
.47 \pm .011\end{array}$ & $\begin{array}{l}.51 \pm .010 \\
.52 \pm .009\end{array}$ & $\begin{array}{l}.53 \pm .010 \\
.53 \pm .008\end{array}$ & $\begin{array}{ll}.54^{a} \pm & .010 \\
.57^{b} \pm .011\end{array}$ & $\begin{array}{l}.55 \pm .010 \\
.56 \pm .009\end{array}$ & $\begin{array}{l}.57 \pm .007 \\
.59 \pm .010\end{array}$ & $\begin{array}{l}.57 \pm .008 \\
.54 \pm .010\end{array}$ & $\begin{array}{l}.61 \pm .010 \\
.59 \pm .007\end{array}$ & $\begin{array}{l}.52 \pm .007 \\
.51 \pm .008\end{array}$ \\
\hline
\end{tabular}

$\mathrm{ab}_{\text {Means }}$ in the same column withln a trait are significantly $(P<.10)$ different 
SIMPLE PHENOTYPIC CORRELATIONS ( $r$ ) BETWEEN CERTAIN LAMB RECORDS FOR VARIOUS

TRAITS AND SIMPLE LINEAR REGRESSIONS (b) OF CERTAIN LATER LAMB RECORDS

ON EARLIER LAMB RECORDS FOR LAMBS BORN TO THE FOUR GROUPS OF EWES

\begin{tabular}{|c|c|c|c|c|c|c|c|c|}
\hline \multirow{2}{*}{ Lamb Traits } & \multicolumn{4}{|c|}{ Single-Reared Ewes, $15 \mathrm{mo}$. } & \multicolumn{4}{|c|}{ Single-Reared Ewes, $24 \mathrm{mo}$. } \\
\hline & $\mathrm{b}$ & $s_{b}{ }^{e}$ & $r$ & $\frac{f}{N}$ & $\mathrm{~b}$ & $\mathrm{~S}_{\mathrm{b}}{ }^{\mathrm{e}}$ & $\mathbf{r}$ & $N^{f}$ \\
\hline $\begin{array}{ll}\text { Birth Weight } & \\
\text { Records 3-8 } & \text { Record } 1^{\mathrm{b}} \\
\text { Records } 3-8 ; & \text { Record } 2{ }^{\mathrm{c}} \\
\text { Records } 3-8 ; & \text { Record } 12^{\mathrm{d}}\end{array}$ & $\begin{array}{l}0.16 \\
0.23 \\
0.33\end{array}$ & $\begin{array}{l}0.08 \\
0.06 \\
0.09\end{array}$ & $\begin{array}{l}0.21 \\
0.36 \\
0.37\end{array}$ & $\begin{array}{l}80 \\
77 \\
80\end{array}$ & $\begin{array}{l}0.10 \\
0.17 \\
0.20\end{array}$ & $\begin{array}{l}0.13 \\
0.14 \\
0.17\end{array}$ & $\begin{array}{l}0.13 \\
0.20 \\
0.20\end{array}$ & $\begin{array}{l}35 \\
36 \\
36\end{array}$ \\
\hline $\begin{array}{l}\text { Av. Daily Gain } \\
\text { Birth - } 70 \text { Days } \\
\quad \text { Records } 3-8 ; \text { Record } 1 \\
\text { Records } 3-8 ; \text { Record } 2 \\
\text { Records 3-8; Record } 12\end{array}$ & $\begin{array}{l}0.20 \\
0.26 \\
0.17\end{array}$ & $\begin{array}{l}0.09 \\
0.10 \\
0.09\end{array}$ & $\begin{array}{l}0.24 \\
0.39 \\
0.20\end{array}$ & $\begin{array}{l}62 \\
64 \\
75\end{array}$ & $\begin{array}{l}0.21 \\
0.18 \\
0.23\end{array}$ & $\begin{array}{l}0.13 \\
0.11 \\
0.11\end{array}$ & $\begin{array}{l}0.28 \\
0.28 \\
0.32\end{array}$ & $\begin{array}{l}31 \\
32 \\
36\end{array}$ \\
\hline $\begin{array}{ll}\text { 70-Day Weight } & \\
\text { Records 3-8; Record } 1 \\
\text { Records 3-8; Record } 2 \\
\text { Records 3-8; Record } 12\end{array}$ & $\begin{array}{l}0.23 \\
0.30 \\
0.26\end{array}$ & $\begin{array}{l}0.09 \\
0.10 \\
0.01\end{array}$ & $\begin{array}{l}0.27 \\
0.40 \\
0.32\end{array}$ & $\begin{array}{l}62 \\
64 \\
75\end{array}$ & $\begin{array}{l}0.17 \\
0.19 \\
0.22\end{array}$ & $\begin{array}{l}0.11 \\
0.09 \\
0.10\end{array}$ & $\begin{array}{l}0.25 \\
0.30 \\
0.33\end{array}$ & $\begin{array}{l}31 \\
32 \\
36\end{array}$ \\
\hline $\begin{array}{l}\text { Av. Daily Gain } 70 \text { Days } \\
\text { to Market } \\
\text { Records } 3-8 ; \text { Record } 1 \\
\text { Records } 3-8 \text {; Record } 2 \\
\text { Records } 3-8 ; \text { Record } 12\end{array}$ & $\begin{array}{l}0.10 \\
0.01 \\
0.10\end{array}$ & $\begin{array}{l}0.04 \\
0.05 \\
0.05\end{array}$ & $\begin{array}{l}0.11 \\
0.03 \\
0.13\end{array}$ & $\begin{array}{l}55 \\
59 \\
70\end{array}$ & $\begin{array}{l}0.17 \\
-.03 \\
0.13\end{array}$ & $\begin{array}{l}0.14 \\
0.19 \\
0.17\end{array}$ & $\begin{array}{l}0.21 \\
-.03 \\
0.12\end{array}$ & $\begin{array}{l}31 \\
29 \\
36\end{array}$ \\
\hline
\end{tabular}


TABLE XXX (Continued)

\begin{tabular}{|c|c|c|c|c|c|c|c|c|}
\hline \multirow[t]{2}{*}{ Lamb Traits } & \multicolumn{4}{|c|}{ Twin-Reared Ewes, $15 \mathrm{mo}$. } & \multicolumn{4}{|c|}{ Twin-Reared Ewes, $24 \mathrm{mo}$. } \\
\hline & $\mathrm{b}$ & $\mathrm{s}_{\mathrm{b}}^{\mathrm{e}}$ & $r$ & $\mathrm{~N}^{\mathrm{f}}$ & $\mathrm{b}$ & $\mathrm{s}_{\mathrm{b}}^{\mathrm{e}}$ & $\mathrm{r}$ & $\mathrm{N}^{\mathrm{f}}$ \\
\hline $\begin{array}{l}\text { Birth Weight } \\
\quad \text { Records 3-8 }{ }^{a} \text {; Record } 1^{\mathrm{b}} \\
\text { Records 3-8; Record 2c } \\
\text { "Records 3-8; Record 12d }\end{array}$ & $\begin{array}{l}0.18 \\
0.12^{g} \\
0.22\end{array}$ & $\begin{array}{l}0.09 \\
0.09 \\
0.12\end{array}$ & $\begin{array}{l}0.25 \\
0.18^{\mathrm{g}} \\
0.25\end{array}$ & $\begin{array}{l}52 \\
51 \\
52\end{array}$ & $\begin{array}{l}0.38 \\
0.42^{h} \\
0.40\end{array}$ & $\begin{array}{l}0.18 \\
0.12 \\
0.15\end{array}$ & $\begin{array}{l}0.38 \\
0.49^{h} \\
0.43\end{array}$ & $\begin{array}{l}37 \\
26 \\
27\end{array}$ \\
\hline $\begin{array}{l}\text { Av. Daily Gain Birth to } \\
70 \text { Day }\end{array}$ & & & & & & & & \\
\hline $\begin{array}{lll}\text { Records } 3-8 ; \text { Record } 1 \\
\text { Records } 3-8 ; \text { Record } 2 \\
\text { Records } 3-8 ; \text { Record } 12\end{array}$ & $\begin{array}{l}0.04 \\
0.22 \\
0.10\end{array}$ & $\begin{array}{l}0.08 \\
0.11 \\
0.11\end{array}$ & $\begin{array}{l}0.08 \\
0.26 \\
0.23\end{array}$ & $\begin{array}{l}42 \\
46 \\
51\end{array}$ & $\begin{array}{l}0.07 \\
0.26 \\
0.20\end{array}$ & $\begin{array}{l}0.13 \\
0.19 \\
0.17\end{array}$ & $\begin{array}{l}0.11 \\
0.31 \\
0.29\end{array}$ & $\begin{array}{l}23 \\
21 \\
24\end{array}$ \\
\hline $\begin{array}{l}\text { 70-Day Weight } \\
\text { Records 3-8; Record } 1 \\
\text { Records 3-8; Record } 2 \\
\text { Records 3-8; Record } 12\end{array}$ & $\begin{array}{l}0.08 \\
0.28 \\
0.15\end{array}$ & $\begin{array}{l}0.08 \\
0.12 \\
0.11\end{array}$ & $\begin{array}{l}0.16 \\
0.30 \\
0.20\end{array}$ & $\begin{array}{l}42 \\
46 \\
51\end{array}$ & $\begin{array}{l}0.03 \\
0.24 \\
0.21\end{array}$ & $\begin{array}{l}0.16 \\
0.17 \\
0.19\end{array}$ & $\begin{array}{l}0.04 \\
0.34 \\
0.32\end{array}$ & $\begin{array}{l}23 \\
21 \\
24\end{array}$ \\
\hline $\begin{array}{l}\text { Av. Daily Gain } 70 \text { Days } \\
\text { to Market } \\
\text { Records } 3-8 ; \text { Record } 1 \\
\text { Records } 3-8 ; \text { Record } 2 \\
\text { Records } 3-8 ; \text { Record } 12\end{array}$ & $\begin{array}{l}0.10 \\
0.10 \\
0.09\end{array}$ & $\begin{array}{l}0.12 \\
0.14 \\
0.12\end{array}$ & $\begin{array}{l}0.12 \\
0.13 \\
0.14\end{array}$ & $\begin{array}{l}38 \\
45 \\
51\end{array}$ & $\begin{array}{l}0.13 \\
0.12 \\
0.15\end{array}$ & $\begin{array}{l}0.10 \\
0.14 \\
0.12\end{array}$ & $\begin{array}{l}0.18 \\
0.20 \\
0.24\end{array}$ & $\begin{array}{l}23 \\
18 \\
24\end{array}$ \\
\hline
\end{tabular}

Records 3-8 = The av. performance of the 3rd through 8 th lambs born to the ewes.

$\mathrm{b}_{\text {Record }} 1=$ The performance of the lst lamb born to the ewes.

CRecord 2 = The performance of the 2 nd lamb born to the ewes.

dRecord $12=$ The av performance of the 1 st and 2 nd lambs born to the ewes.

eThe standard error of the regression coefficient.

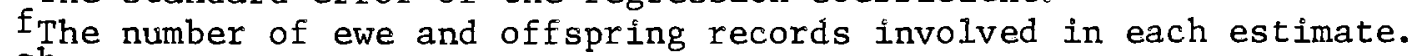

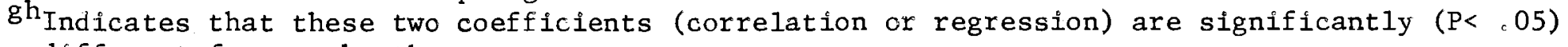
different from each other. 
SIMPLE LINEAR REGRESSION COEFFICIENTS (b) OF LAMB TRAITS ON EWE TRAITS FOR THE FOUR GROUPS OF EWES AND PRESENTED BY AGE OF DAM

\begin{tabular}{|c|c|c|c|c|c|c|c|c|c|c|c|c|c|c|c|c|c|c|c|}
\hline \multirow{2}{*}{$\begin{array}{l}\text { Ewe and } \\
\text { Lamb Traft. }\end{array}$} & $\begin{array}{l}15 \\
\text { mo. }\end{array}$ & $\mathbf{N}$ & $\begin{array}{l}24 \\
\text { mo. }\end{array}$ & $\mathrm{N}$ & $\begin{array}{l}36 \\
\text { mo. }\end{array}$ & $\mathbf{N}$ & $\begin{array}{l}48 \\
\text { mo. }\end{array}$ & $\mathbf{N}$ & $\begin{array}{l}60 \\
\text { mo. }\end{array}$ & $\mathrm{N}$ & $\begin{array}{l}72 \\
\text { mo. }\end{array}$ & $\mathbf{N}$ & $\begin{array}{l}84 \\
\text { mo. }\end{array}$ & $\mathbf{N}$ & $\begin{array}{l}96 \\
\text { mo. }\end{array}$ & $\mathrm{N}$ & Avg. & $\mathrm{s}_{\mathrm{b}}$ & $\mathrm{N}$ \\
\hline & \multicolumn{19}{|c|}{ Twin-Reared Ewes That Lambed First at 15 Months } \\
\hline $\begin{array}{l}\text { Bt. wt. }{ }^{a} \\
\text { ADG bt-70 }{ }^{b} \\
70-\text { day wt. }{ }^{c} \text { d } \\
\text { ADG } 70-\pi k t .\end{array}$ & $\begin{array}{l}0.18 \\
-.14 \\
-.09 \\
0.06\end{array}$ & $\begin{array}{l}72 \\
61 \\
61 \\
57\end{array}$ & $\begin{array}{l}0.38 * \\
-.23 \\
-.08 \\
0.07\end{array}$ & $\begin{array}{l}54 \\
47 \\
47 \\
46\end{array}$ & $\begin{array}{l}0.20 \\
-.11 \\
-.07 \\
-.09\end{array}$ & $\begin{array}{l}51 \\
47 \\
47 \\
47\end{array}$ & $\begin{array}{l}0.35 \star \\
-.24 \\
-.10 \\
-.13\end{array}$ & $\begin{array}{l}38 \\
33 \\
33 \\
33\end{array}$ & $\begin{array}{l}0.11 \\
-.27 \\
-.03 \\
-.10^{\mathrm{e}}\end{array}$ & $\begin{array}{l}18 \\
15 \\
15 \\
15\end{array}$ & $\begin{array}{l}-.04 \\
-.10 \\
-.03 \\
-.02\end{array}$ & $\begin{array}{l}17 \\
15 \\
15 \\
15\end{array}$ & $\begin{array}{l}0.53 \\
0.31 \\
0.04 \\
-.01\end{array}$ & $\begin{array}{l}13 \\
10 \\
10 \\
10\end{array}$ & $\begin{array}{l}0.32 \\
0.51 \\
0.04 \\
-.35\end{array}$ & $\begin{array}{r}13 \\
7 \\
7 \\
7\end{array}$ & $\begin{array}{l}0.24 \\
-.10 \\
-.09 \\
0.07\end{array}$ & $\begin{array}{l}0.11 \\
0.12 \\
-.17 \\
0.13\end{array}$ & $\begin{array}{l}72 \\
72 \\
72 \\
72\end{array}$ \\
\hline \multicolumn{20}{|c|}{ Single-Reared Ewes That Lambed First at 15 Months } \\
\hline 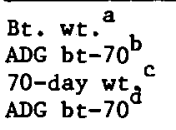 & $\begin{array}{l}0.12 \\
-.21 \\
-.08 \\
0.04\end{array}$ & $\begin{array}{l}90 \\
75 \\
75 \\
70\end{array}$ & $\begin{array}{l}0.10 \\
0.07 \\
0.23 \\
-.02\end{array}$ & $\begin{array}{l}81 \\
68 \\
68 \\
65\end{array}$ & $\begin{array}{l}0.06 \\
0.02 \\
0.03 \\
-.15\end{array}$ & $\begin{array}{l}80 \\
69 \\
69 \\
64\end{array}$ & $\begin{array}{l}0.17 \\
0.04 \\
0.02 \\
0.04\end{array}$ & $\begin{array}{l}72 \\
62 \\
62 \\
61\end{array}$ & $\begin{array}{l}0.02 \\
0.25 \\
0.08 \\
0.41\end{array}$ & $\begin{array}{l}50 \\
44 \\
44 \\
44\end{array}$ & $\begin{array}{l}-.01 \\
0.06 \\
0.05 \\
0.01\end{array}$ & $\begin{array}{l}44 \\
40 \\
40 \\
40\end{array}$ & $\begin{array}{l}0.09 \\
0.32 \\
0.03 \\
0.02\end{array}$ & $\begin{array}{l}36 \\
24 \\
24 \\
24\end{array}$ & $\begin{array}{l}0.02 \\
0.25 \\
0.02 \\
0.01\end{array}$ & $\begin{array}{l}32 \\
27 \\
27 \\
25\end{array}$ & $\begin{array}{l}0.06 \\
0.04 \\
0.07 \\
0.10\end{array}$ & $\begin{array}{l}0.06 \\
0.10 \\
0.09 \\
0.10\end{array}$ & $\begin{array}{l}90 \\
90 \\
90 \\
90\end{array}$ \\
\hline \multicolumn{20}{|c|}{ Twin-Reared Ewes That Lambed First at 24 Months } \\
\hline $\begin{array}{l}\text { Bt. wt. }{ }^{a} \\
\text { ADG bt }-70^{b} \\
70-d a y ~ w t^{c} \\
\text { ADG bt }-70^{d}\end{array}$ & $\begin{array}{l}0.00 \\
0.00 \\
0.00 \\
0.00\end{array}$ & $\begin{array}{l}0 \\
0 \\
0 \\
0\end{array}$ & $\begin{array}{l}0.18 \\
-.29 \\
-.06 \\
-.09\end{array}$ & $\begin{array}{l}39 \\
37 \\
37 \\
37\end{array}$ & $\begin{array}{l}-.02 \\
-.15 \\
-.07 \\
0.10\end{array}$ & $\begin{array}{l}38 \\
34 \\
34 \\
30\end{array}$ & $\begin{array}{l}0.15 \\
-.10 \\
0.02 \\
-.31\end{array}$ & $\begin{array}{l}26 \\
20 \\
20 \\
20\end{array}$ & $\begin{array}{l}0.24 \\
0.05 \\
-.03 \\
0.13\end{array}$ & $\begin{array}{l}18 \\
17 \\
17 \\
17\end{array}$ & $\begin{array}{l}0.17 \\
-.14 \\
-.08 \\
-.12\end{array}$ & $\begin{array}{l}18 \\
17 \\
17 \\
17\end{array}$ & $\begin{array}{l}-.24 \\
0.05 \\
-.04 \\
0.04\end{array}$ & $\begin{array}{l}16 \\
13 \\
13 \\
12\end{array}$ & $\begin{array}{l}-.09 \\
-.13 \\
-.02 \\
0.47\end{array}$ & $\begin{array}{l}12 \\
11 \\
11 \\
11\end{array}$ & $\begin{array}{l}0.04 \\
-.12 \\
-.05 \\
-.03\end{array}$ & $\begin{array}{l}0.12 \\
0.13 \\
0.37 \\
0.12\end{array}$ & $\begin{array}{l}39 \\
37 \\
39 \\
39\end{array}$ \\
\hline \multicolumn{20}{|c|}{ Single-Reared Ewes That Lambed First at 24 Months } \\
\hline 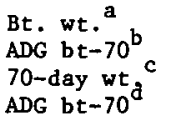 & $\begin{array}{l}0.00 \\
0.00 \\
0.00 \\
0.00\end{array}$ & $\begin{array}{l}0 \\
0 \\
0 \\
0\end{array}$ & $\begin{array}{l}0.00 \\
-.15 \\
-.02 \\
-.12\end{array}$ & $\begin{array}{l}34 \\
34 \\
34 \\
34\end{array}$ & $\begin{array}{l}-.11 \\
0.27 \\
0.20 \\
-.04\end{array}$ & $\begin{array}{l}36 \\
32 \\
32 \\
29\end{array}$ & $\begin{array}{l}0.24 \\
-.27 \\
-.03 \mathrm{f} \\
0.11\end{array}$ & $\begin{array}{l}34 \\
32 \\
32 \\
32\end{array}$ & $\begin{array}{l}-.08 \\
0.08 \\
-.06 \\
0.12\end{array}$ & $\begin{array}{l}28 \\
29 \\
27 \\
27\end{array}$ & $\begin{array}{l}-.17 \\
0.29 \\
0.03 \\
-.07\end{array}$ & $\begin{array}{l}28 \\
25 \\
25 \\
25\end{array}$ & $\begin{array}{l}0.05 \\
-.18 \\
-.05 \\
0.01\end{array}$ & $\begin{array}{l}24 \\
20 \\
20 \\
19\end{array}$ & $\begin{array}{l}-.14 \\
-.05 \\
0.02 \\
0.21\end{array}$ & $\begin{array}{l}20 \\
16 \\
16 \\
15\end{array}$ & $\begin{array}{l}0.02 \\
-.08 \\
-.04 \\
0.04\end{array}$ & $\begin{array}{l}0.08 \\
0.18 \\
0.10 \\
0.14\end{array}$ & $\begin{array}{l}39 \\
39 \\
39 \\
39\end{array}$ \\
\hline
\end{tabular}

* Significantly ( $\mathrm{P}: .05)$ different from zero

$a_{B 1 \text { th weights of ewes and lambs }}$

bverage datly gain from birth to 70 days for ewes and lambs

c70-day welghts of ewes and lambs

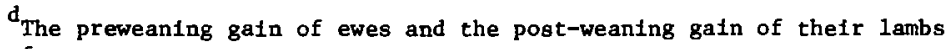

${ }^{\text {ef }}$ Coefficients within a column between single and twin-reared ewes within each age of dam at first lambing are different (P<.05) from each other 
SIMPLE LINEAR REGRESSION COEFFICIENTS (b) OF LAMB TRAITS ON EWE TRAITS FOR SINGLE AND TWIN-REARED EWES PRESENTED BY AGE OF DAM (POOLED OVER AGE OF EWE AT FIRST LAMBING)

\begin{tabular}{|c|c|c|c|c|c|c|c|c|c|c|c|c|c|c|c|c|c|c|c|}
\hline $\begin{array}{c}\text { Ewe and } \\
\text { Lamb Trait }\end{array}$ & $\begin{array}{l}15 \\
\text { mo. }\end{array}$ & $\mathrm{N}$ & $\begin{array}{l}24 \\
\text { mo. }\end{array}$ & $\mathrm{N}$ & $\begin{array}{l}36 \\
\text { mo. }\end{array}$ & $\mathrm{N}$ & $\begin{array}{l}48 \\
\text { mo. }\end{array}$ & $\mathrm{N}$ & $\begin{array}{l}60 \\
\text { mo. }\end{array}$ & $\mathrm{N}$ & $\begin{array}{l}72 \\
\text { mo. }\end{array}$ & $\mathrm{N}$ & $\begin{array}{l}84 \\
\text { mo. }\end{array}$ & $\mathrm{N}$ & $\begin{array}{l}96 \\
\text { mo. }\end{array}$ & $\mathrm{N}$ & Avg. & $\mathrm{s}_{\mathrm{b}}$ & $\mathrm{N}$ \\
\hline \multicolumn{20}{|c|}{ Single-Reared Ewes } \\
\hline $\begin{array}{l}\text { Bt. wt. }{ }^{a} \\
\text { ADG bt-70 }{ }^{b} \\
70-d a y ~ w t \\
\text { ADG bt }-70^{d}\end{array}$ & $\begin{array}{l}0.06 \\
-.17 \\
-.08 \\
-.05\end{array}$ & $\begin{array}{l}90 \\
75 \\
75 \\
70\end{array}$ & $\begin{array}{l}0.01 \\
0.06 \\
0.09 \\
0.03\end{array}$ & $\begin{array}{r}120 \\
102 \\
102 \\
99\end{array}$ & $\begin{array}{l}0.09 \\
-.04 \\
-.01 \\
-.15\end{array}$ & $\begin{array}{r}116 \\
101 \\
101 \\
93\end{array}$ & $\begin{array}{l}0.10 \\
0.10 \\
0.06 \\
0.08\end{array}$ & $\begin{array}{r}107 \\
94 \\
94 \\
93\end{array}$ & $\begin{array}{l}-.03 \\
0.25 \star \\
0.02 \\
0.22\end{array}$ & $\begin{array}{l}78 \\
71 \\
71 \\
71\end{array}$ & $\begin{array}{l}0.00 \\
0.04 \\
0.03 \\
-.01\end{array}$ & $\begin{array}{l}72 \\
65 \\
65 \\
65\end{array}$ & $\begin{array}{l}0.04 \\
0.22 \\
0.08 \\
0.14\end{array}$ & $\begin{array}{l}70 \\
49 \\
49 \\
48\end{array}$ & $\begin{array}{l}0.02 \\
0.25 \\
0.04 \\
0.01\end{array}$ & $\begin{array}{l}52 \\
43 \\
43 \\
40\end{array}$ & $\begin{array}{l}0.02 \\
0.00 \\
0.02 \\
0.07\end{array}$ & $\begin{array}{l}0.05 \\
0.08 \\
0.08 \\
0.08\end{array}$ & $\begin{array}{l}129 \\
129 \\
129 \\
129\end{array}$ \\
\hline \multicolumn{20}{|c|}{ Twin-Reared Ewes } \\
\hline 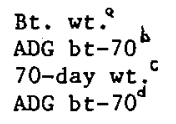 & $\begin{array}{l}0.19 \\
-.17 \\
-.05 \\
-.01\end{array}$ & $\begin{array}{l}72 \\
61 \\
61 \\
57\end{array}$ & $\begin{array}{l}0.17 \\
-.20^{*} \\
-.18 \\
0.09\end{array}$ & $\begin{array}{l}91 \\
84 \\
84 \\
83\end{array}$ & $\begin{array}{l}0.18 \\
-.08 \\
-.05 \\
-.03\end{array}$ & $\begin{array}{l}89 \\
81 \\
81 \\
77\end{array}$ & $\begin{array}{l}0.28 * \\
-.10 \\
-.09 \\
0.12\end{array}$ & $\begin{array}{l}64 \\
53 \\
53 \\
53\end{array}$ & $\begin{array}{l}0.14 \\
-.05 \\
-.06 \\
-.25\end{array}$ & $\begin{array}{l}36 \\
32 \\
32 \\
32\end{array}$ & $\begin{array}{l}-.14 \\
0.25 \\
0.07 \\
0.14\end{array}$ & $\begin{array}{l}35 \\
32 \\
32 \\
32\end{array}$ & $\begin{array}{l}0.25 \\
-.07 \\
-.01 \\
0.11\end{array}$ & $\begin{array}{l}29 \\
23 \\
23 \\
22\end{array}$ & $\begin{array}{l}0.32 \\
0.51 * \\
0.09 \\
-.15\end{array}$ & $\begin{array}{l}25 \\
18 \\
18 \\
18\end{array}$ & $\begin{array}{l}0.14 \\
-.11 \\
-.07 \\
0.02\end{array}$ & $\begin{array}{l}0.09 \\
0.09 \\
0.09 \\
0.09\end{array}$ & $\begin{array}{l}111 \\
111 \\
111 \\
111\end{array}$ \\
\hline
\end{tabular}

${ }^{*}$ Significantly $(P * .05)$ different from zero

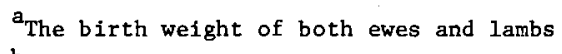

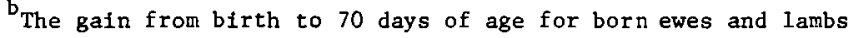

${ }^{c}$ The 70-day weight of both ewes and lambs

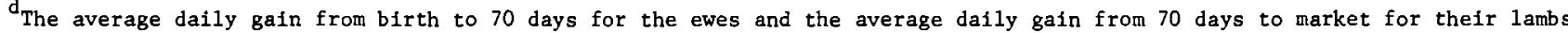

ef Coefficients within a column between single and twin-reared ewes are significantly $(P=.05)$ different from each other 


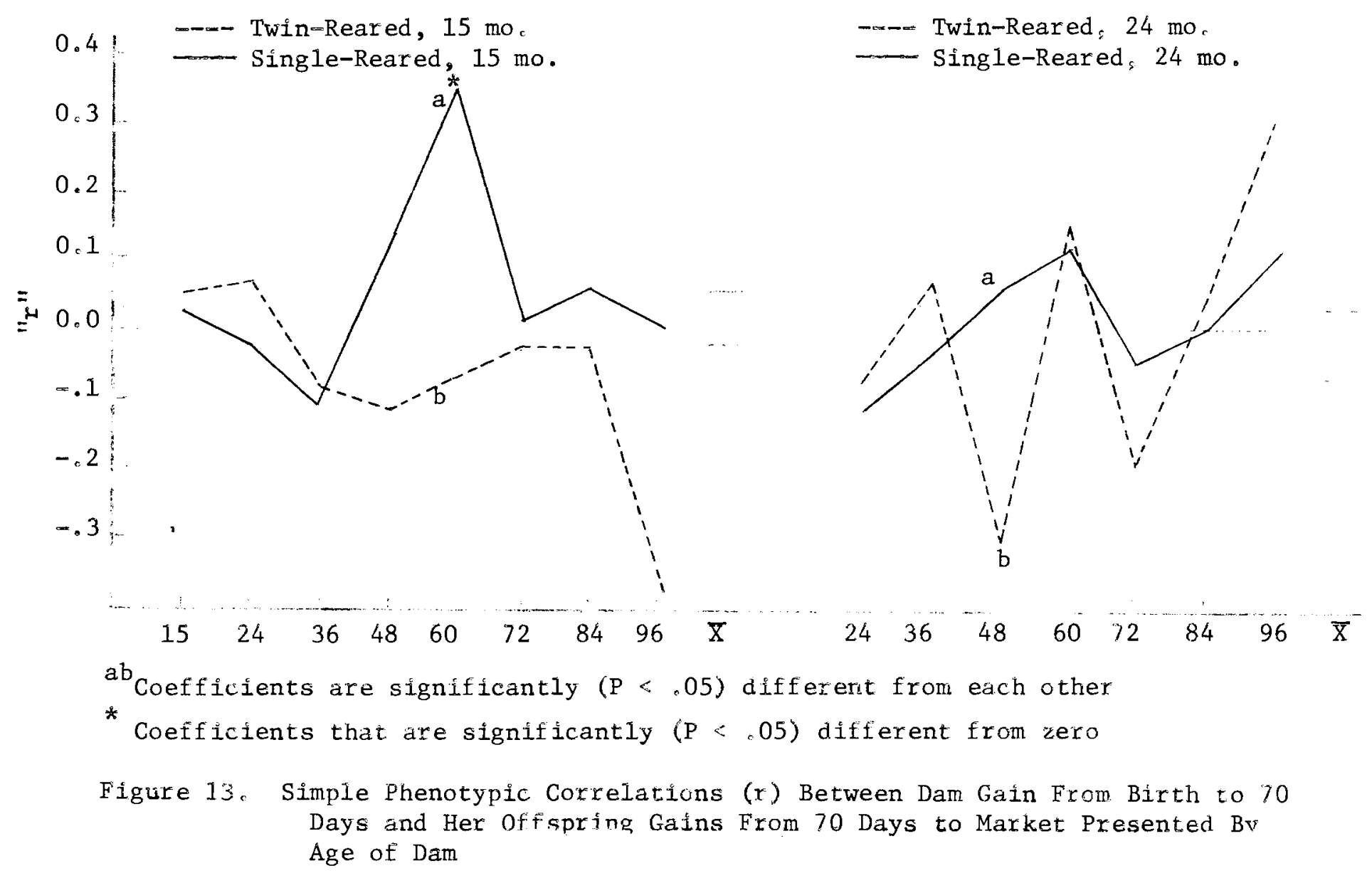




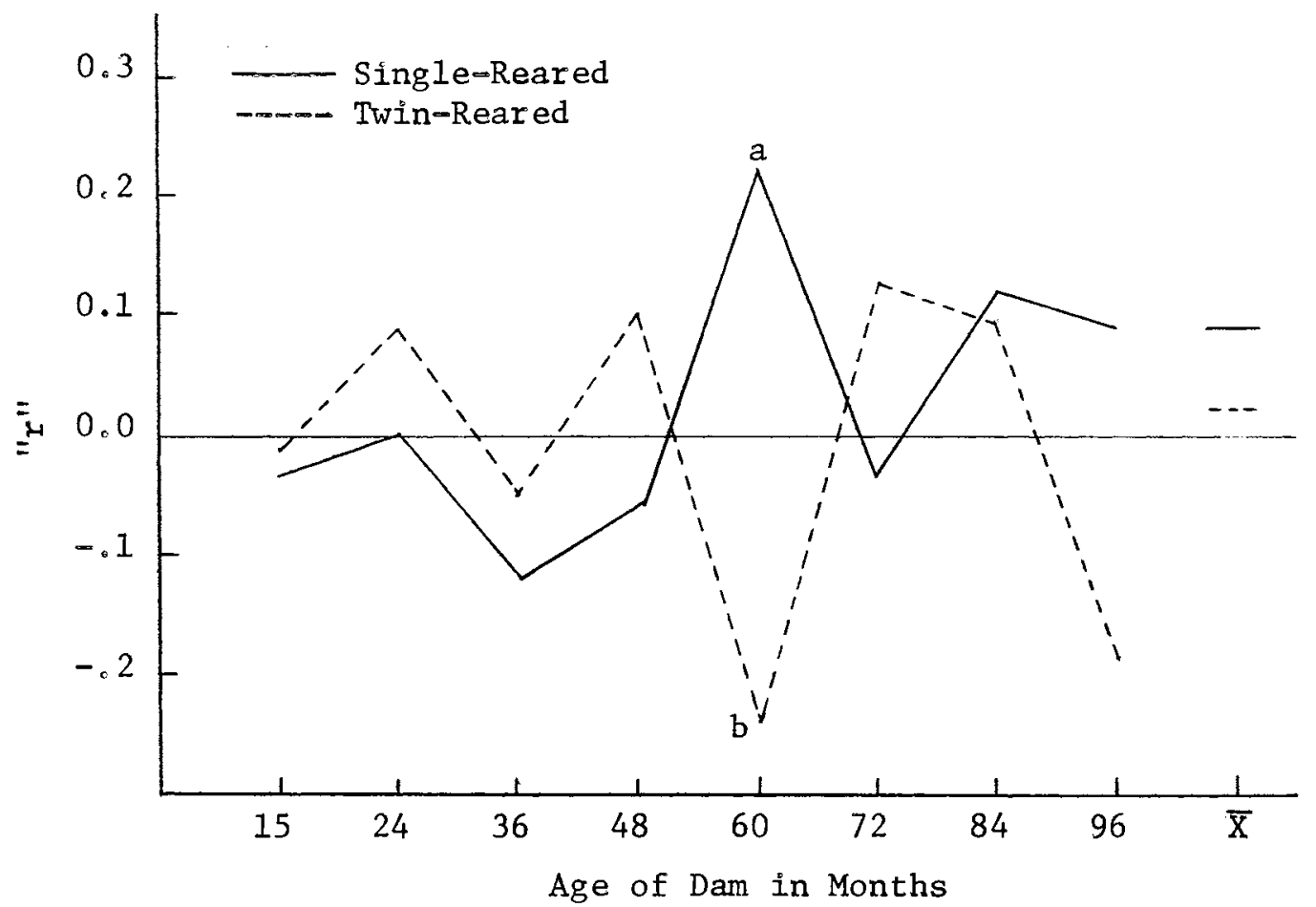

${ }^{a b}$ Correlation coefficients significantly $(P<.05)$ different from each other

Figure 14. Simple Phenotypic Correlations ( $r$ ) Between Dam Gain From Birth to 70 Days And Her Offspring Gains From 70 Days to Market Presented by Age of Dam With the Data Pooled Over Age of Dam at First Lambing 


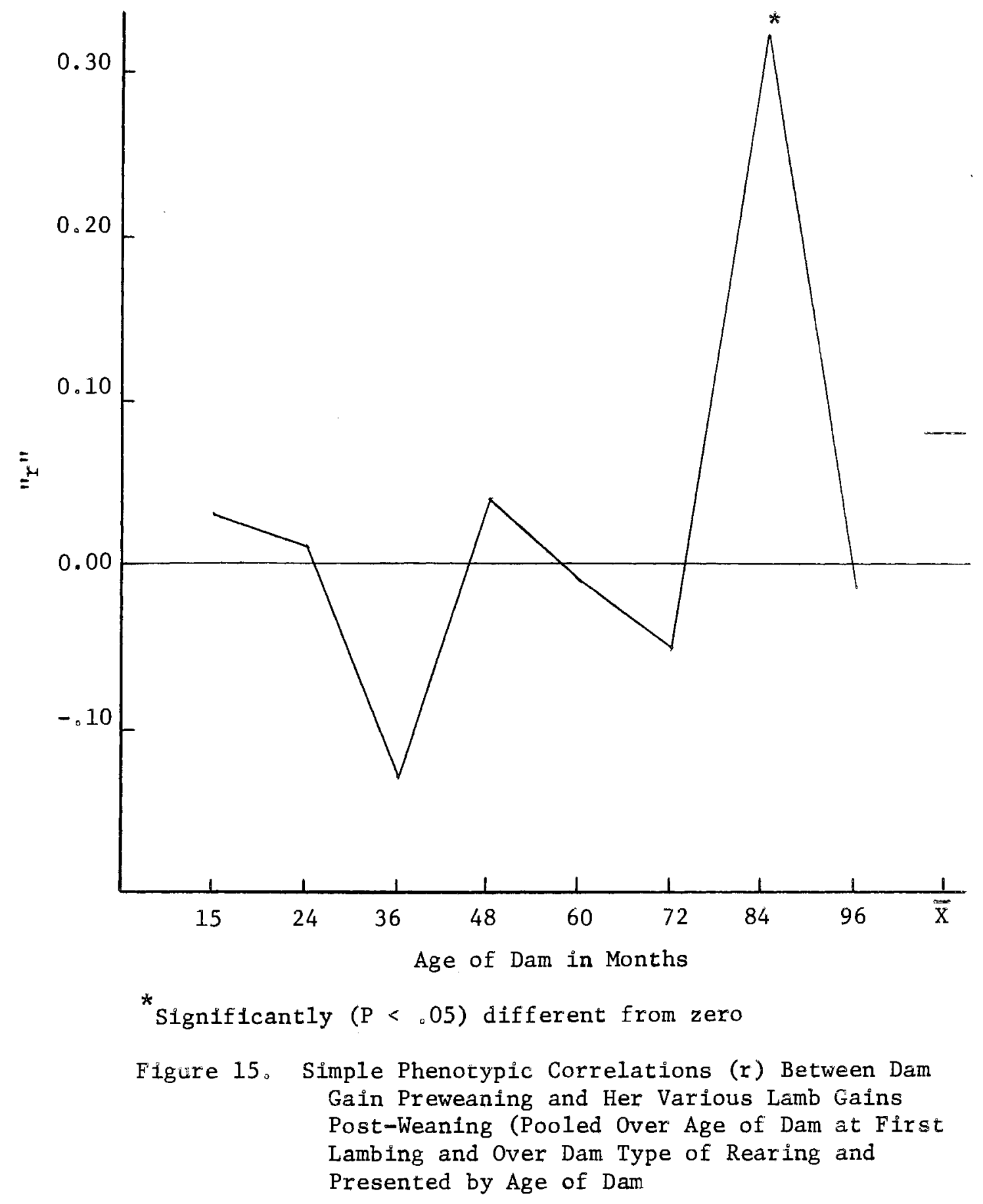




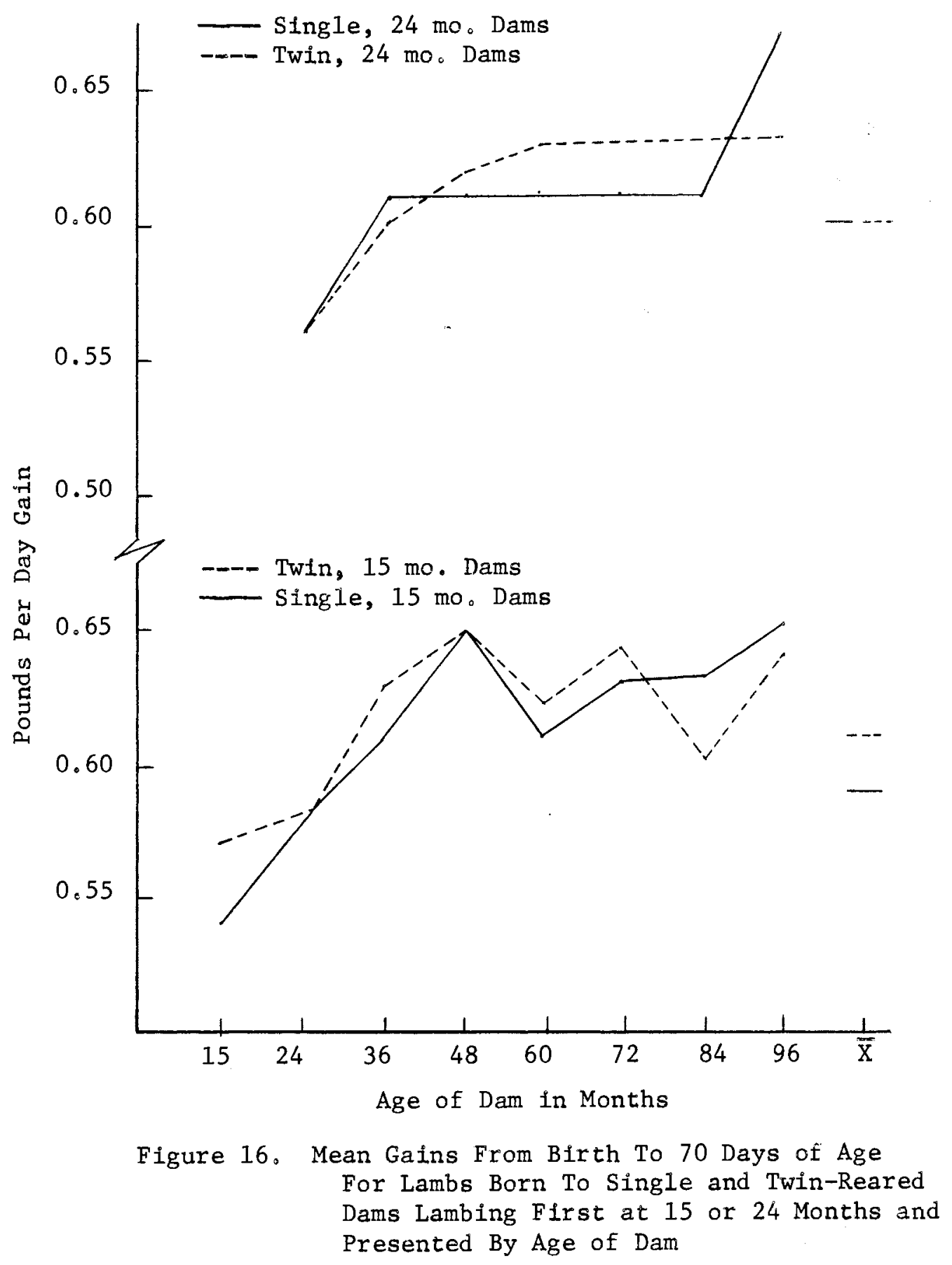




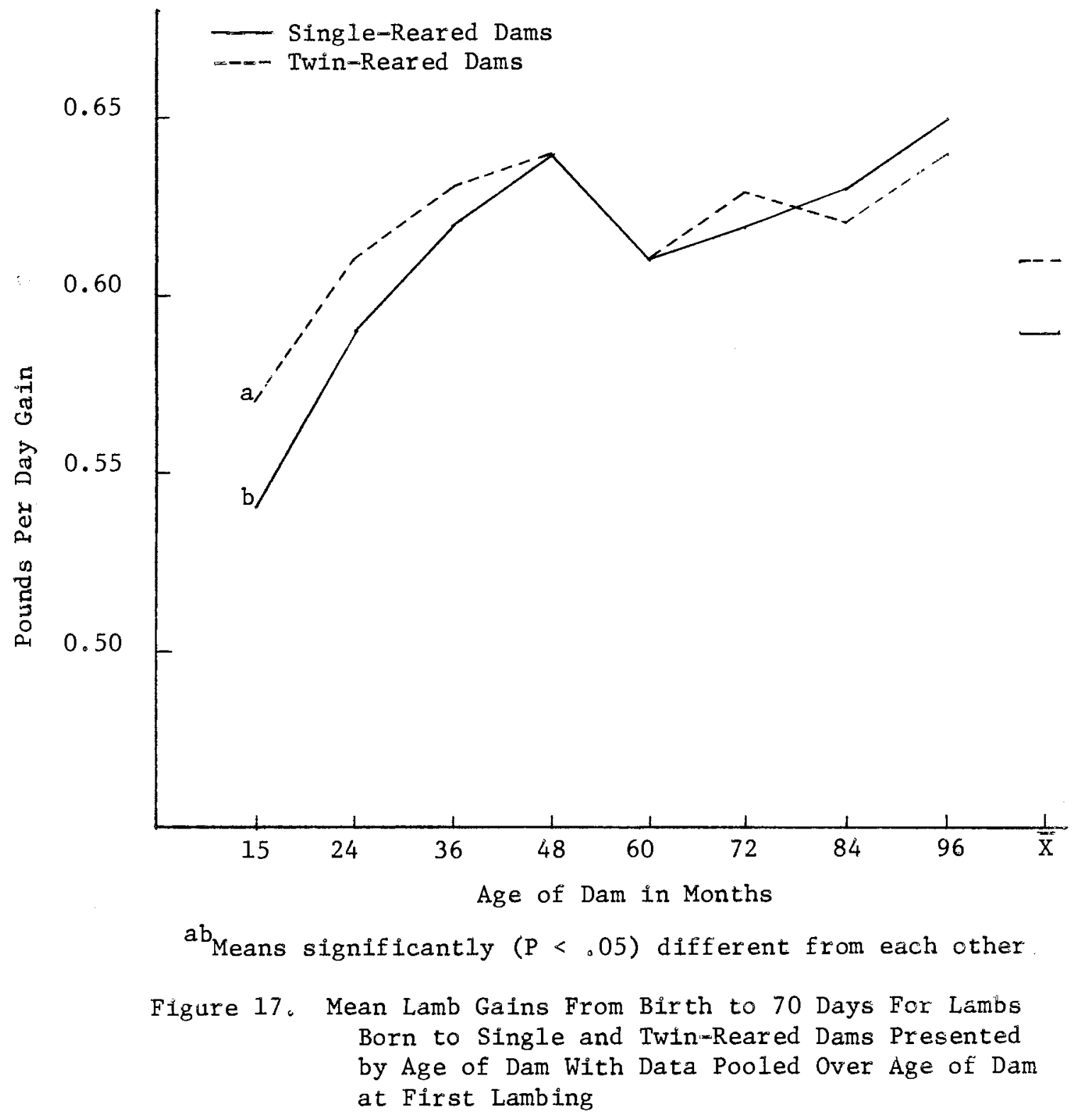




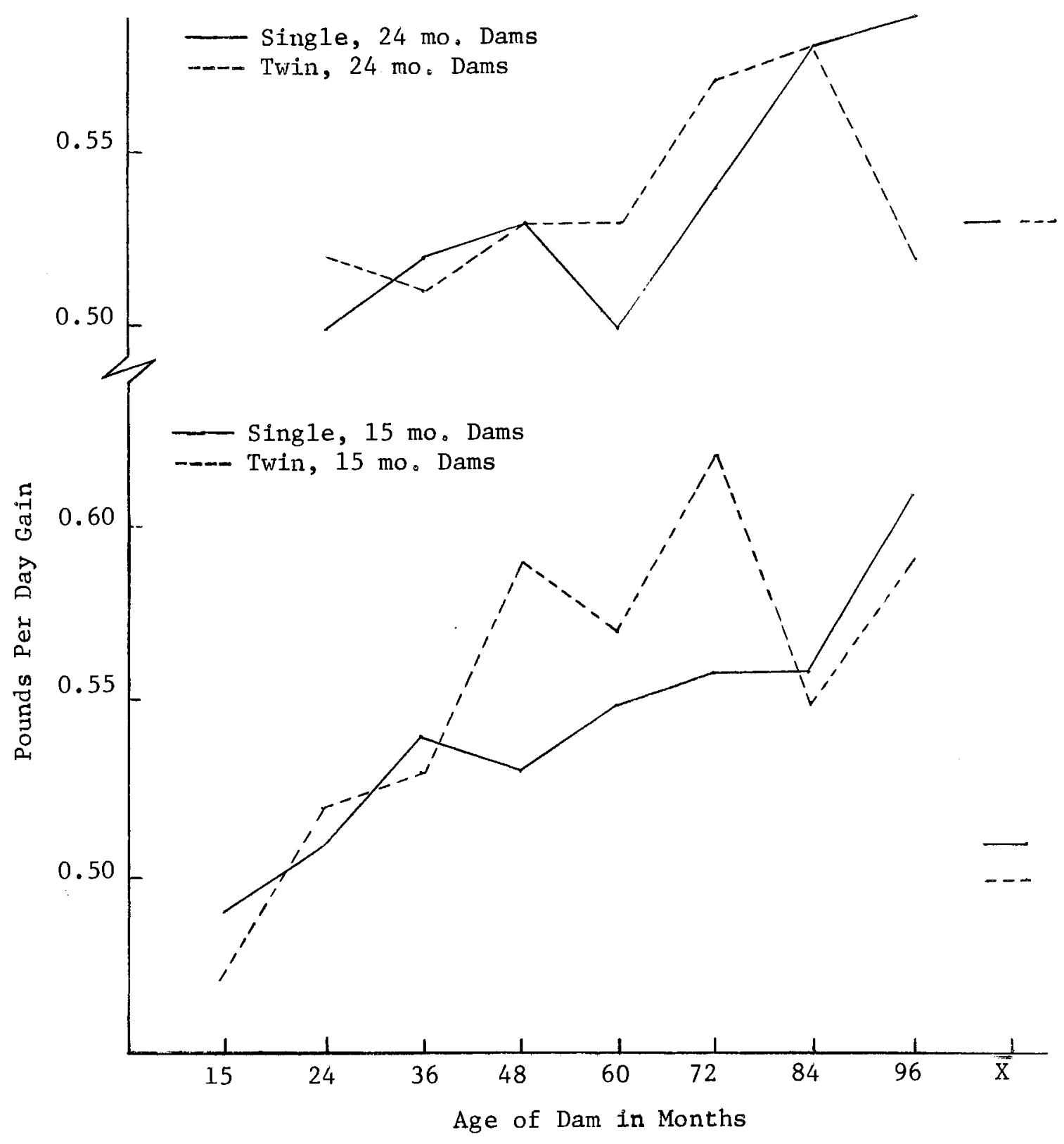

Figure 18. Mean Lamb Gain From 70 Days to Market for Lambs Born to Single and Twin-Reared Dams Lambing First at 15 or 24 Months and Presented by Age of Dam. 


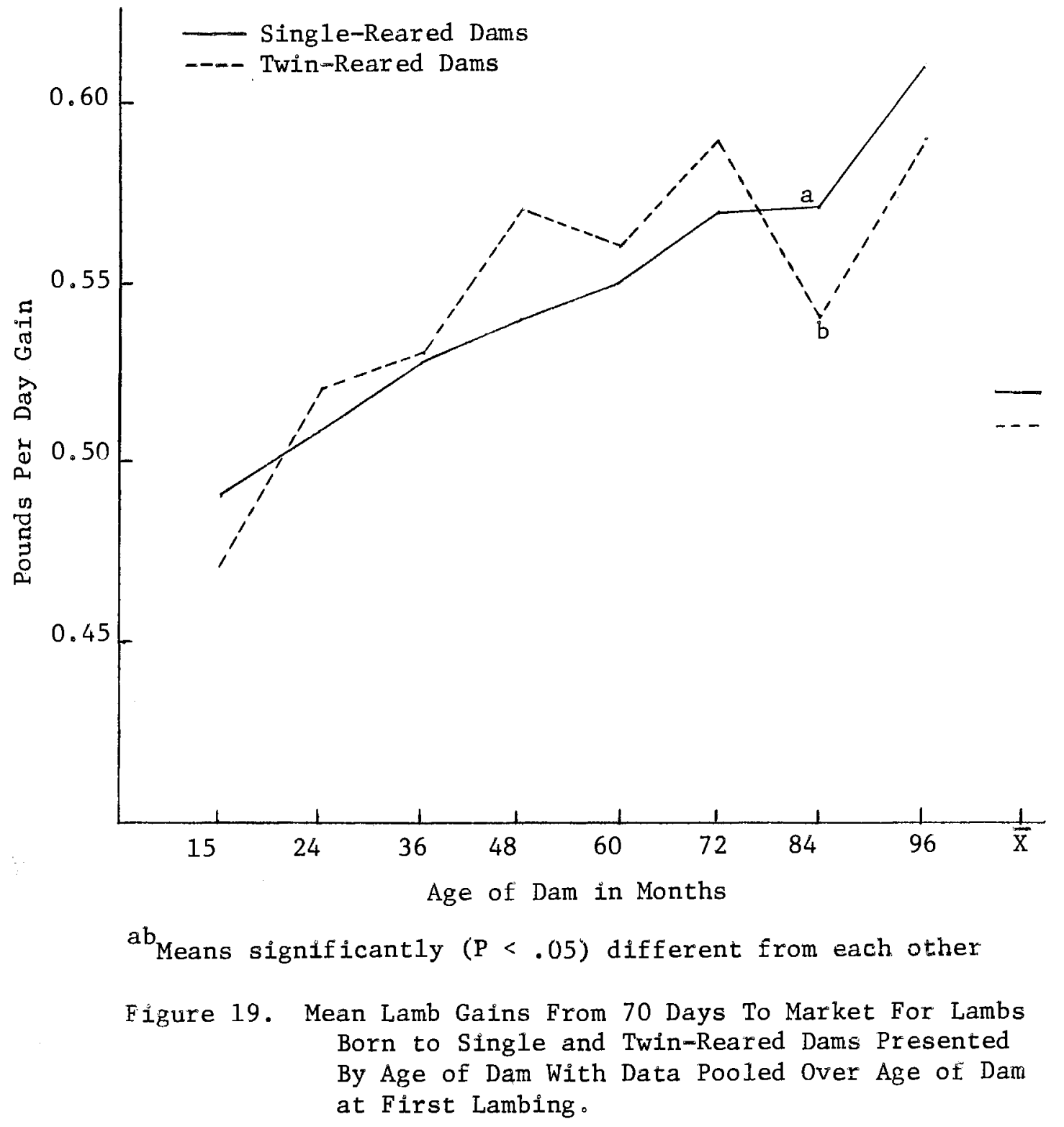




\author{
ח \\ VITA \\ Mike B. Gould \\ Candidate for the Degree of \\ Doctor of Philosophy
}

Thesis: RELATIONSHIP BETWEEN PREWEANING GROWTH RATE OF FEMALE LAMBS AND THE GROWTH OF THEIR OFFSPRING

Major Field: Animal Breeding

Biographical:

Personal Data: Born at Watonga, Oklahoma, March 18, 1940, the son of $\mathrm{Mr}$. and Mrs. H. W. Gould; married Ruth Ann Kelly, November 22, 1963; the father of one son, John Thomas Gould.

Education: Received the Bachelor of Science degree from Oklahoma State University in August, 1962 with a major in Animal Husbandry. Recelved the Master of Science degree from Oklahoma State University in August, 1970 with a major in Animal Science.

Experience: Reared on a farm in central Oklahoma; Missouri Extension Service, 1962-1963; Shepherd and Herdsman, Fort Reno Livestock Research Station, 1963-1968; Graduate Assistant, Oklahoma State University, 1968-1973.

Date of Degree: May, 1973 